\title{
9 Quellenverzeichnis
}

\subsection{Archivquellen und unveröffentlichte Primärquellen}

Archives Nationales de France, Paris: Serie F 90.

Library of Congress, Washington, DC:

Manuscript Collection: Thomas Nast Papers.

Manuscript Collection: Federal Writers' Project of the United States Work Projects

Administration.

Louisiana and Lower Mississippi Valley Collections. Louisiana State University Libraries:

Special Collections in the Hill Memorial Library, Baton Rouge, LA:

Embree, Joseph. Family Papers, 1826-1894: MS 692.

Conner, Lemuel P. Family Papers, 1818 -1853: MSS 81, 1403, 1431, 1475, 1551, 1595, 1710 , 1793, 1859, 1934, 1999, hier MS 1403.

National Archives and Records Administration, Washington, DC:

Record Group 7: Records of the Bureau of Entomology and Plant Quarantine, 1863-1956.

Record Group 105: Records of the Field Offices for the State of Louisiana, Bureau of Refugees,

Freedmen, and Abandoned Lands, 1863-1872.

Record Groups 241: Records of the Patent and Trademark Office.

\subsection{Veröffentlichte Quellen}

Abbott, Edith. „A Study of the Early History of Child Labor in America.“ American Journal of Sociology. 1908 Jul 1, 14(1):15-37.

Adam, Hugo G. The Independent Journal. New York: Independent Journal Publishing Co, 1848.

Adams, Andy. The Log of a Cowboy: A Narrative of the Old Trail Days. Boston, MA, New York: Houghton, Mifflin and Company, 1903.

Adams, Angela und Willi Paul Adams. Die Federalist-Artikel. Paderborn, München, Wien, Zürich: Ferdinand Schöningh, 1994.

Adams, Brooks. The Law of Civilization and Decay: An Essay on History. London, New York: S. Sonnenschein \& Co., MacMillan \& Co, 1895.

Adams, Charles Francis. Chapters of Erie and Other Essays. Bedford, MA: Applewood Books, 1871.

Adams, Frank. „Extending the Area of Irrigated Wheat in California for 1918.“ University of California. College of Agriculture. Agricultural Experiment Station. Circular No. 182 (1917).

Adams, Samuel Hopkins. The Great American Fraud. Chicago, IL: P. F. Collier, 1905.

Addams, Jane. Twenty Years at Hull-House: With Autobiographical Notes. New York, Toronto: Signet Classic, 1960.

Adshead, Joseph. On Juvenile Criminals, Reformatories, and the Means of Rendering the Perishing and Dangerous Classes Serviceable to the State. Manchester: Printed by J. Harrison and son, 1856.

Agger, Eugene E. „Our Large Change: The Denominations of the Currency.“ The Quarterly Journal of Economics 32, no. 2 (1918):257-77. 
Alger, Horatio. The Backwoods Boy: Or, The Boyhood and Manhood of Abraham Lincoln. New York: Street and Smith, 1883.

Alger, Horatio. Ragged Dick. Boston, MA: Loring, 1868.

Alger, Horatio. Risen from the Ranks, or, Harry Walton's Success. Philadelphia, PA: J.C. Winston Co, 1874.

Altgeld, John Peter. Reasons for Pardoning Fielden, Neebe and Schwab. Chicago, IL: [Selbstverlag?], 1893.

Altgeld, John Peter. Reply to Roosevelt: Being a Speech of Ex-Governor John Peter Altgeld, Delivered before the Ohio Association of Democratic Clubs of Toledo, August 1, 1900. [Toledo, OH: Selbstverlag? 1900].

American Federation of Labor. Some Reasons for Chinese Exclusion. Meat vs. Rice. American Manhood against Asiatic Coolieism. Which Shall Survive? Washington, DC: Government Printing Office, 1902.

Anderson, Isabel. Presidents and Pies: Life in Washington 1897-1919. Boston, MA, New York: Houghton Mifflin Company, 1920.

Anderson, James. „Statistics of Telegraphy.“ Journal of the Statistical Society of London 35, no. 3 (1872):272-326.

Anderson, William. Self-Made Men. London: J. Snow, 1865.

[Anonymous]. Acht Opfer des Klassenhasses. Zürich: Mitgliedschaft Deutscher Sozialisten, 1888.

[Anonymous]. The Anarchist Riot in Chicago - A Dynamite Bomb Exploding Among the Police [McCormick Strike, Haymarket Square], 1886.

[Anonymous]. Convention to Consider the Opening of Indian Territory: Proceedings of the Convention to Consider the Opening of Indian Territory Held at Kansas City, Mo. February 8, 1888. Kansas City, MO: Press of Ramsey, Millett \& Hudson, 1888.

[Anonymous]. Die maskirte Dame des Weissen Hauses oder, der Ku-Klux-Klan. Philadelphia, PA, 1868.

[Anonymous]. [,Review of Social Statics, or the Conditions Essential to Human Happiness Specified, and the First of Them Developed by Herbert Spencer"]. The North American Review. 1858; 86(178):60-83.

[Anonymous]. „The Eugenics Record Office.“ Science. 1913, 37(954):553-554.

[Anonymous]. „The Federal Reserve - Zionist Jewish Private Bankers.“ [Web Page]: http://www. rense.com/general85/feddrec.htm. Gesehen am 9.7.2015.

[Anonymous]. „The First Dynamite Bomb Thrown in America“ May 4th, 1886. The Personnel of the Great Anarchist Trial at Chicago. Begun Monday June 21st 1886. Ended Friday, August 20th 1886. Chicago, IL: Published by the Inter Ocean Co, 1886.

[Anonymous]. The Forty Acres Documents: What Did the United States Really Promise the People Freed from Slavery? Baton Rouge, LA: House of Songhay Commission for Positive Education, 1994.

[Anonymous]. Life of Jim Crow, Showing How He Got His Inspiration As a Poet the Number of Fathers Who Claimed Him When He Got Up in the World, Though None Would Own Him Before: the Magic Spring „Way in De Woods Ob Ole Kaintuck, Where De Little Fairy Told Him of His Futur Greatness and Consequence in De World“: His Interview With Gineral Jackson, With a Whole Basket Full of Incidents Which Befel Him Before He Made His Grand Jump on the Stage! Philadelphia, PA: For Sale, Wholesale and Retail by James M'Minn at No. 96 North Seventh Street, and at No. 44 Strawberry St, 1835. 
[Anonymous]. The Masked Lady of the White House or, The Ku-Klux-Klan: A Most Startling Exposure. Philadelphia, PA: C.W. Alexander, 1868.

[Anonymous]. Memorial of the Indian Delegates against the Passage by Congress of Any Act for the Organization of United States Territorial Government over the Indian Country. Washington, DC: Printed by J. L. Ginck, 1880.

[Anonymous]. The New Testament of Our Lord and Saviour Jesus Christ: Translated into the Indian Language. Ordered to Be Printed by the Commissioners of the United Colonies in New England, at the Charge, and With the Consent of the Corporation in England for the Propagation of the Gospel Amongst the Indians in New-England. Cambridge, MA: Samuel Green and Marmaduke Johnson, 1661.

[Anonymous]. Remonstrance of the Cherokee, Creek, Choctaw, and Seminole Delegations against the Organization of the Indian Territory into a Territory of the United States. Washington, DC: Printed by John L. Ginck, 1876.

[Anonymous]. The Story of Pullman. Chicago, IL: Blakely \& Rogers, 1892.

[Anonymous]. The United States Biographical Dictionary and Portrait Gallery of Eminent and Self-Made Men. Chicago, IL, New York: American biographical publishing company, 1875.

Antin, Mary. From Plotzk to Boston. Boston, MA: W. B. Clarke, 1899.

Antin, Mary. The Promised Land. Boston, MA, New York: Houghton Mifflin Company, 1912.

Antin, Mary. They Who Knock at Our Gates: A Complete Gospel of Immigration. Boston, MA, New York: Houghton Mifflin Company, 1914.

Antin, Mary. Vom Ghetto ins Land der Verheißung. Stuttgart: R. Lutz, 1913.

Archivo Nacional de Cuba. Inventario General del Archivo de la Delegación del Partido Revolucionario Cubano en Nueva York (1892-1898). Tomo 1. Habana, Cuba: Impr. „El Siglo XX,“ Sociedad Editorial Cuba Contemporánea, 1918.

Atwood, Henry Clinton. The Master Workman: Or, True Masonic Guide: Containing Elucidations of the Fundamental Principles of Free-Masonry, Operative and Speculative - Morally and Beneficially: With Embellishments and Explanations of All the Degrees of the Blue, Or Symbolic Lodge, Chapter, Council, Encampment, Consistory, and Supreme Grand Council, Designed and Properly Arranged Agreeably to the Mode of Work and Lecturing. Also, a Complete Classification of the Various Rites to Wit: the Egyptian, Scottish, French, Ancient and Modern York. New York: Simons \& Macoy, 1850.

Aveling, Edward Bibbins und Marx Aveling, Eleanor. The Working-Class Movement in America. London: Swan, Sonnenschein \& Co, 1891.

Babbitt, Edwin D. Vital Magnetism, the Life-Fountain Being an Answer to Dr. Brown-Sequard's Lectures on Nerve Force: The Magnetic Theory Defended and a Better Philosophy of Cure Explained. New York: Published by E.D. Babbitt, 1874.

George E. Baker (Hg.). The Works of William Henry Seward. Boston, New York: Houghton, Mifflin and Company, 1884.

Baker, Ray Stannard. Following the Color Line. New York: Doubleday, Page \& Company, 1908. Baker, Ray Stannard. The Spiritual Unrest. New York: Frederick A. Stokes Company, 1910.

Ball, Terence. Abraham Lincoln: Political Writings and Speeches. Cambridge, New York: Cambridge University Press, 2013.

Bancroft, Edgar Addison. The Chicago Strike of 1894. Chicago, IL: Gunthorp-Warren, 1895.

Bancroft, Frederic (Hg.). Speeches, Correspondence and Political Papers of Carl Schurz. New York: Negro Universities Press, 1969. 
Barrick, Michael Mathers. The Dangerous Delusion of American Exceptionalism. Granite Falls, NC: Defiantly Rural Pub, 2011.

Bateman, Newton und Selby, Paul. Historical Encyclopedia of Illinois. Chicago, IL: Munsell Publishing Company, 1913.

Bauer, Stephan und Maylander, Alfred. „The Road to the Eight-Hour Day.“ Monthly Labor Review 9, no. 2 (1919):41-65.

Benedict, Michael Les. The Fruits of Victory: Alternatives in Restoring the Union, 1865-1877. Lanham, MD: University Press of America, 1986.

Bennett, Elmer F. and Seaton, Fred A. Federal Indian Law. Washington DC: Government Printing Office, 1958.

Berkman, Alexander. Prison Memoirs of an Anarchist. New York: Mother Earth Publishing Association, 1912.

Berkman, Alexander. und Goldman, Emma. Anarchism on Trial: Speeches of Alexander Berkman and Emma Goldman before the United States District Court in the City of New York, July, 1917. New York: Mother Earth Publishing Association, 1917.

Berlin, Ira, Reidy, Joseph P. und Rowland, Leslie S.. The Black Military Experience. Cambridge, New York: Cambridge University Press, 1982.

Berner, Brad K. The Spanish-American War: A Documentary History with Commentaries. Lanham, MD: Rowman \& Littlefield, 2014.

Bevans, Charles I. Treaties and Other International Agreements of the United States of America, 1776-1949. 13 Bände. Washington, DC: Government Printing Office, $1968-1976$.

Bioletti, Frederic T. „Control of Raisin Insects.“ University of California. College of Agriculture. Agricultural Experiment Station. Circular No. 135 (1915).

Bioletti, Frederic T., Cruess, W. V und Davi, Horace Denan. Changes in the Chemical Composition of Grapes during Ripening. Berkeley, CA: University of California Press, 1918.

Blake, Tom. „Avoyelles Parish, Louisiana. Largest Slaveholders from 1860 Slave Census Schedules and Surname Matches for African Americans on 1870 Census.“ [Web Page]: http://freepages.genealogy.rootsweb.ancestry.com/ ajac/laavoyelles.htm. Gesehen am 13.7.2015.

Bland, R. P. und Poor, Henry V.. „Debtor and Creditor.“ The North American Review 127, no. 263 (1878):117-31.

Blaustein, Albert P. und Zangrando, Robert L.. Civil Rights and African Americans: A Documentary History. Evanston, IL: Northwestern University Press, 1991.

Blumentritt, Ferdinand. Die Philippinen: Eine übersichtliche Darstellung der ethnographischen und historisch-politischen Verhältnisse des Archipels. Hamburg: Verlagsanstalt und Druckereri a.-g. (Vormals J. F. Richter), 1900.

Botkin, Benjamin Albert. The American People in Their Stories, Legends, Tall Tales, Traditions, Ballads and Songs. London: Pilot Press Itd, 1946.

Boutwell, George S. Address by the Hon. Geo. S. Boutwell Delivered in Faneuil Hall, Boston, January 1, 1903 at the Celebration of the Fortieth Anniversary of the Emancipation Proclamation, by the Colored People of Boston and Vicinity. Boston, MA: [The Ant-Imperialist League?], 1903.

Boutwell, George S. The Crisis of the Republic. Boston, MA: D. Estes \& Company, 1900.

Boutwell, George S. Imperialists or Republicans? Address before the Essex Institute, Salem, Mass., January 9, 1899. Washington, DC: Anti-Imperialist League, 1899. 
Boutwell, George S. Mass Meetings of Protest Against the Suppression of Truth About the Philippines, Faneuil Hall, Thursday, March 19, 3 and 8 P.m.: Addresses by George S. Boutwell... [Et al.]. Boston: [The Anti-Imperialist League?], 1903.

Boutwell, George S. The President's Policy War and Conquest Abroad, Degradation of Labor at Home. Chicago, IL: American Anti-Imperialist League, 1900.

Bowers, Edward A. „The Condition of the Forests on the Public Lands of the United States.“ Publications of the American Economic Association 6, no. 1/2 (1891):154-57.

Brace, Charles Loring. The Dangerous Classes of New York and Twenty Years' Work among Them. New York: Wynkoop \& Hallenbeck, 1872.

Bremner, Robert H. Children and Youth in America: A Documentary History. Cambridge, MA: Harvard University Press, 1970-1974.

Bridge, James Howard. The History of the Carnegie Steel Company: An Inside Review of Its Humble Origin and Impressive Growth. New York: The Aldine Book Co, 1903.

Brown, J. G, Lucy Stone und National American Woman Suffrage Association Collection. The History of Equal Suffrage in Colorado, 1868-1898. Denver, CO: News job printing Co., 1898.

Browne, Waldo R. Altgeld of Illinois: A Record of His Life and Work. New York: B. W. Huebsch, 1924.

Brownell, Blaine A. und Warren E Stickle. Bosses and Reformers: Urban Politics in America, 1880-1920. Boston, MA: Houghton Mifflin, 1973.

Brutschke, Fritz. Die landwirtschaftlichen Maschinen in den Vereinigten Staaten von Amerika und der Arbeiterersatz: Bericht des zum Studium des nordamerikanischen landwirtschaftlichen Maschinenwesens entsandten sachverständigen Ingenieur Brutschke. Berlin: Deutsche Landwirtschaftsgesellschaft, 1904.

Bryan, William Jennings. The First Battle: A Story of the Campaign of 1896. Chicago, IL: W. B. Conkey Company, 1898.

Bryan, William Jennings. The Second Battle, or, The New Declaration of Independence, 1776-1900. An Account of the Struggle of 1900. Chicago, Ill: W.B. Conkey Co., 1900.

Bryce, James Bryce. The American Commonwealth. London, New York: Macmillan and Co, 1888.

Bryson, Phillip J. The Economics of Henry George History's Rehabilitation of America's Greatest Early Economist. New York: Palgrave Macmillan, 2011.

Burgoyne, Arthur Gordon. Homestead: A Complete History of the Struggle of July, 1892, Between the Carnegie Steel Company, Limited, and the Amalgamated Association of Iron and Steel Workers. Pittsburgh, PA: Rawsthorne Engraving and Printing Co., 1893.

Byington, Margaret F. Homestead: The Households of a Mill Town. New York: Charities Publication Committee, 1910.

Byington, Margaret F. What Social Workers Should Know about Their Own Communities: An Outline. New York: Charity organization department of the Russell Sage foundation, 1912.

Byler, Charles A. Civil-Military Relations on the Frontier and beyond, 1865-1917. Westport, CT: Praeger Security International, 2006.

Cahan, Richard. A Court That Shaped America: Chicago's Federal District Court from Abe Lincoln to Abbie Hoffman. Evanston, IL: Northwestern University Press, 2002.

Cahill, Cathleen D. Federal Fathers \& Mothers: A Social History of the United States Indian Service, 1869-1933. Chapel Hill, NC: University of North Carolina Press, 2011. 
Caldwell, William B. Notes on the Coal and Iron Ores of Western Kentucky. Frankfort, KY: John D. Woods, 1878.

California, Agricultural Experiment Station, Berkeley, Eugene W Hilgard, Louis Paperelli und Frederick Theodore Bioletti. Report of the Viticultural Work during the Seasons 1883-4 and $1884-5$ [1885 and 1886, 1887-89, 1887-93]. Sacramento, CA: J. J. Ayres, supt. state printing, $1886-1996$.

California und Lester Grant Burnett. State Tenement House Act and State Hotel and Lodging House Act of California. Sacramento, CA: California State Printing Office, 1917.

Capen, Nahum. Reminiscenses of Dr. Spurzheim and George Combe and a Review of the Science of Phrenology, from the Period of Its Discovery by Dr. Gall, to the Time of the Visit of George Combe to the United States, 1838, 1840. New York: Fowler \& Wells, 1881.

Carnegie, Andrew. The Autobiography of Andrew Carnegie. New York: PublicAffairs, 2011. Carnegie, Andrew. The Autobiography of Andrew Carnegie and His Essay: The Gospel of Wealth. Mineola, NY, n.p., 2014.

Carnegie, Andrew. The Gospel of Wealth. London: F. C. Hagen \& Co., 1889.

Carpenter, Mary. Reformatory Schools, for the Children of the Perishing and Dangerous Classes, and for Juvenile Offenders. London: C. Gilpin, etc., etc., 1851.

Carter, Sarah. Montana Women Homesteaders: A Field of One's Own. Helena, MT: Farcountry Press, 2009.

Carwardine, William H. The Pullman Strike. Chicago, IL: C. H. Kerr and Company, 1894. Castillo y Jiménez, José M. del. El Katipunan ó El Filibusterismo En Filipinas Crónica llustrada Con Documentos, Autógrafos y Fotograbados. Madrid: Imp. del Asilo de huérfanos del S. C. de Jesús, 1897.

Cerruti, F. E. und Eusebio de Salazar y Mazarredo. Peru and Spain: Being a Narrative of the Events Preceding and Following the Seizure of the Chincha Islands with an Analysis of the Despatch of Señor Salazar y Mazarredo. London: Williams and Norgate, 1864.

Chamberlain, J. S. Success or, The Triumphs and Achievements of Self-Made Men. Chicago, IL: Merchants' specialty Co., 1891.

Chubbuck, Emily. Allen Lucas, the Self-Made Man. New York: Lewis Colby \& Co, 1847.

City of Los Angeles. Department of Public Service. Complete Report on Construction of the Los Angeles Aqueduct. Los Angeles, CA: The Standard Printing Co, 1913.

Clark, J. Reuben. Memorandum on the Monroe Doctrine. Washington, DC: Government Printing Office, 1930.

Classroom Teaching Resources. „Homestead Census.“ [Web Page]: http://archives. dreamhosters.com/items/show/128. Gesehen am 13.7.2015.

Cleveland, Grover. The Self-Made Man in American Life. New York: T.Y. Crowell, 1897.

Clifton, Robert T. Barbs, Prongs, Points, Prickers, \& Stickers a Complete and Illustrated Catalogue of Antique Barbed Wire. Norman, OK: University of Oklahoma Press, 1970.

Clower, George W. „A Letter on Sherman's March through Georgia.“ The Georgia Historical Quarterly 37, no. 2 (1953):160-162.

Coates, James. How to Mesmerize: A Manual of Instruction in the History, Mysteries, Modes of Procedure, and Arts of Mesmerism or Animal Magnetism, Clairvoyance, Thought Reading, and Mesmeric Entertainments. Chicago, IL: National Institute of Science, 1897.

Commonwealth of Pennsylvania, Senate und House. Report of the Committee Appointed to Investigate the Railroad Riots in July 1877. Harrisburg, PA: Lanes and Hart, 1878. 
Comstock, Anthony. Frauds Exposed or, How the People Are Deceived and Robbed, and Youth Corrupted. New York: J. H. Brown, 1880.

Conant, Charles A. „The Economic Basis of ,Imperialism“. “ The North American Review 167, no. 502 (1898): $326-40$.

Constantine, J. Robert (Hg.). Letters of Eugene V. Debs. Urbana, IL: University of Illinois Press, 1990.

Craig, Adam. Room at the Top, or, How to Reach Success, Happiness, Fame and Fortune: With Biographical Notices of Successful, Self-Made Men, Who Have Risen from Obscurity to Fame... Also, Rules for Behavior in Society. Augusta, ME: True, 1884.

Croly, Herbert David. Marcus Alonzo Hanna His Life and Work. New York: The Macmillan Company, 1912.

Croly, Herbert David. The Promise of American Life. New York: The Macmillan Company, 1909. Cumming, Kate. Gleanings from Southland: Sketches of Life and Manners of the People of the South Before, During and After the War of Secession, With Extracts from the Author's Journal and Epitome of the New South. Birmingham, AL: Roberts \& Son, 1895.

Currie, David P. The Constitution of the United States: A Primer for the People. Chicago, IL: University of Chicago Press, 1988.

Curtis, George Ticknor und YA Pamphlet Collection (Library of Congress). The Case of the Virginius, Considered with Reference to the Law of Self-Defence. New York: Baker, Voorhis $\&$ Co., etc., etc., 1874.

Cushing, Caleb. The Treaty of Washington: Its Negotiation, Execution, and the Discussions Relating thereto. Freeport, NY: Books for Libraries Press, 1970.

Dana, Richard Henry. The Corrupt Practice Act: The Nominating Machinery, and the Australian Ballot System of Massachusetts. A Paper Presented at the Twenty-Ninth Annual Meeting of the New York State Bar Association, Held at... Albany, N.Y., on the 16th and 17th of January, 1906, and Reprinted from the Twenty-Ninth Annual Report of the Proceedings of the Association. Albany, NY: 1906.

Danver, Steven Laurence. Revolts, Protests, Demonstrations, and Rebellions in American History: An Encyclopedia. Santa Barbara, CA: ABC-CLIO, 2011.

Darwin, Charles. On the Origin of Species by Means of Natural Selection. London: J. Murray, 1859.

Davenport, Charles Benedict und Steggerda, Morris. Race Crossing in Jamaica. Washington, DC: Carnegie Institution of Washington, 1929.

Davenport, Charles Benedict. The Feebly Inhibited. Cold Spring Harbor, NY: n.p., 1915.

Davenport, Charles Benedict. State Laws Limiting Marriage Selection Examined in the Light of Eugenics. Cold Spring Harbor, NY: n.p.1913.

Davenport, Charles Benedict, Harry Hamilton Laughlin, David Fairchild Weeks, Edward Ransom Johnstone und Henry Herbert Goddard. The Study of Human Heredity. Cold Spring Harbor, NY: n.p. 1911.

De Leon, Daniel und Job Harriman. The Socialist Trade and Labor Alliance versus the „Pure and Simple“ Trade Union: A Debate Held at the Grand Opera House, New Haven, Conn., November 25, 1900, Between Daniel De Leon Representing the Socialist Trade \& Labor Alliance and the Socialist Labor Party, and Job Harriman Representing the „Pure and Simple“ Trade Union and the Social Democratic Party. New York: New York Labor News Company, 1900.

Dell, Floyd. Moon-Calf: A Novel. New York: A. A. Knopf, 1920. 
[Democratic Party]. Official Proceedings of the Democratic National Convention Held in 1864. Chicago, IL: The Times Steam Book and Job Printing House, 1864.

Denny, Edward W. The Story of Manhattan Beach: A Practical and Picturesque Delineation of Its History, Development and Attractions. New York: F. Hart \& Co., 1879.

Dewey, John. Experience and Nature. Chicago, IL, London: Open Court Publishing Company, 1925.

Dewey, John. The Quest for Certainty: A Study of the Relation of Knowledge and Action. New York: Minton, Balch, 1929.

Dickerson, Donna Lee. The Reconstruction Era: Primary Documents on Events from 1865 to 1877. Westport, CT: Greenwood Press, 2003.

Dixon, Edward H. The Terrible Mysteries of the Ku-Klux-Klan: A Full Expose of the Forms, Objects, and „Dens“ of the Secret Order: With a Complete Description of Their Initiation. From the Confession of a Member. New York: n.p., 1868.

Donaldson, Thomas. „The Public Lands of the United States.“ The North American Review 133, no. 297 (1881):204-13.

Donaldson, Thomas Corwin. The Public Domain: Its History, With Statistics, With References to the National Domain, Colonization, Acquirement of Territory, the Survey, Administration and Several Methods of Sale and Disposition of the Public Domain of the United States, With Sketch of Legislative History of the Land States and Territories, and References to That of Several Foreign Governments. Washington, DC: Government Printing Office, 1884.

Donnelly, Ignatius. Caesar's Column: A Story of the Twentieth Century. Chicago, IL: F. J. Schulte \& Company, 1890.

Dooley, Patricia L. The Early Republic: Primary Documents on Events from 1799 to 1820. Westport, CT: Greenwood Press, 2004.

Dredge, James. The Pennsylvania Railroad: Its Organization, Construction, and Management. London, New York: Offices of „Engineering.“ John Wiley and Sons, 1879.

Dunn, Robert. „Some Observations on the Psychological Differences Which Exist among the Typical Races of Man.“ In: Transactions of the Ethnological Society of London 3 (1865), S. 9-25.

Dunning, Nelson A. The Farmers' Alliance History and Agricultural Digest. Washington, DC: Alliance publishing Company, 1891.

Ellis, Charles. Statehood: A Lecture Delivered in the Salt Lake Theatre, February 7th, 1892. Salt Lake City, UT: C. Ellis, 1892.

Eltzbacher, Paul. Anarchism. New York, London: Benj. R. Tucker. A.C. Fifield, 1908.

Encyclopaedia Britannica, Inc. The Annals of America: 1858-1865. The Crisis of the Union, Vol. 9. Chicago, IL: Encyclopædia Britannica, 1976-1987.

Estabrook, Arthur Howard und Davenport, Charles Benedict. The Nam Family: A Study in Cacogenics. Cold Spring Harbor, NY, Lancaster, PA: The New era printing company, 1912.

Farningham, Marianne. New World Heroes: Lincoln and Garfield. The Life-Story of Two Self-Made Men, Whom the People Made Presidents. London: W. Scott, 1884?

Fitch, Thomas W. Bessemer Steel: Ores and Methods. St. Louis, MO: M. Renshaw, 1882.

Flank, Lenny. The Haymarket Trial Selected Testimony from the Trial of the Chicago Anarchists: Albert Parsons and August Spies. St. Petersburg, FL: Red and Black Publishers, 2011.

Folks, Homer. „Poverty and Parental Dependence as an Obstacle to Child Labor Reform.“ In: National Child Labor Committee (Hg.). Child Labor and the Republic. New York: National Child Labor Committee, 1907, S. 1-8. 
Forten, Charlotte L. „Life on the Sea Islands.“ Atlantic Monthly XIII (1864):587-69, 666-676.

Forten, Charlotte L. Journal. New York: Dryden Press, 1953.

Forten, Charlotte L. The Journal of Charlotte Forten a Free Negro in the Slave Era. New York: Norton, 1981.

Forten, Charlotte L., Christy Steele, Kerry A. Graves und Linda Clavel. A Free Black Girl before the Civil War the Diary of Charlotte Forten, 1854. Mankato, MN: Blue Earth Books, 2000.

Forten, Charlotte L und Brenda E Stevenson. The Journals of Charlotte Forten Grimké. New York: Oxford University Press, 1988.

Foster, William Z. The Great Steel Strike and Its Lessons. New York: B. W. Huebsch, Inc, 1920.

Fraser, James W. A History of Hope: When Americans Have Dared to Dream of a Better Future. New York: Palgrave Macmillan, 2002.

Frégier, Honoré Antoine. Des classes dangereuses : De la population dans les grandes villes. Paris: Chez J.-B. Baillière, 1840.

Friedman, Morris. The Pinkerton Labor Spy. New York: Wilshire book Co., 1907.

Frohnen, Bruce. The American Nation: Primary Sources. Indianapolis, IN: Liberty Fund, 2008.

Garis, Roy L. Immigration Restriction: A Study of the Opposition to and Regulation of Immigration into the United States. New York: The Macmillan Company, 1927.

Garland, Hamlin. Main-Travelled Roads: Six Mississippi Valley Stories. Boston, MA: Arena, 1891.

Garvin, W. L und S. O Daws. History of the National Farmers' Alliance and Co-Operative Union of America. Jacksboro, TX: J. N. Rogers \& Co., printers, 1887.

General Electric Company. GE Works: 2013 Annual Report, General Electric Company, Fairfield, CT, 2014.

George, Henry. The Life of Henry George. Garden City, NY: Doubleday, Page, 1911.

George, Henry. Progress and Poverty. New York: Cosimo Inc., 2005.

George, Henry. Progress and Poverty: An Inquiry into the Cause of Industrial Depressions, and of Increase of Want with Increase of Wealth - The Remedy. San Francisco, CA: W. M. Hinton \& Co., printers, 1879.

Gibson, William. Paris during the Commune: With a Character Sketch by His Wife. London, Nottingham: Howitt and Son, 1895.

Gilbert Holland Montague. „The Legend of the Standard Oil Company.“ The North American Review 181, no. 586 (1905):352-68.

Gill, Thomas P. „Landlordism in America.“ The North American Review 142, no. 350 (1886):52-67.

Goldman, Emma. My Disillusionment in Russia. London: C. W. Daniel Company, 1925.

Gompers, Samuel. „Attitude of Labor towards Government Regulation of Industry.“ Annals of the American Academy of Political and Social Science 32 (1908):75-81.

Gompers, Samuel. „Free Speech and the Injunction Order.“ Annals of the American Academy of Political and Social Science 36, no. 2 (1910):1-10.

Gompers, Samuel. „The Labor Movement and Peace.“ The Advocate of Peace (1894-1920) 67, no. 1 (1905):12-13.

Gompers, Samuel. „The Limitations of Conciliation and Arbitration.“ Annals of the American Academy of Political and Social Science 20 (1902):29-34.

Gompers, Samuel. „Organized Labor in the Campaign.“ The North American Review 155, no. 428 (1892):91-96. 
Gompers, Samuel. „Organized Labor’s Attitude toward Child Labor.“ Annals of the American Academy of Political and Social Science 27 (1906):79-83.

Gompers, Samuel. „The Peace Crusade in Boston. Organized Labor's Contribution to International Peace.“ The Advocate of Peace (1894-1920) 61, no. 5 (1899):110-112.

Gordon, Ann D. (Hg.). The Selected Papers of Elizabeth Cady Stanton and Susan B. Anthony: In the School of Anti-Slavery, 1840 to 1866. New Brunswick, NJ: Rutgers University Press, $1997-2013$.

Grady, Henry Woodfin. The New South: Writings and Speeches of Henry Grady. Savannah, GA: Beehive Press, 1971.

Graf, LeRoy P., Haskins, Ralph W. und Bergeron, Paul H. (Hg.). The Papers of Andrew Johnson. Knoxville, TN: University of Tennessee Press, 1967-2000.

Grant, Ulysses S. Personal Memoirs. New York: Modern Library, 1999.

Grey, Zane. The Heritage of the Desert: A Novel. New York, London: Harper \& Brothers, 1910.

Grey, Zane. The Last Trail: A Story of Early Days in the Ohio Valley. New York: A.L. Burt Company, 1909.

Grey, Zane. The Light of Western Stars: A Romance. New York: Grosset \& Dunlap, 1914.

Grey, Zane. The Spirit of the Border: A Romance of the Early Settlers in the Ohio Valley. New York: A.L. Burt Company, 1906.

Guenther, Carl Hilmar, Beckmann Hurst, Regina und Kamphoefner, Walter D.. An Immigrant Miller Picks Texas: The Letters of Carl Hilmar Guenther. San Antonio, TX: Maverick Pub. Co, 2001.

Hacker, Louis Morton und Zahler, Helene Sara. The Shaping of the American Tradition. New York: Columbia University Press, 1947.

Hakim, Joy. A History of Us: Sourcebook and Index. Documents That Shaped the American Nation. New York: Oxford University Press, 2002.

Hamilton, Alexander, Madison, James und John, Jay. The Federalist Papers. Minneapolis, MN: Filiquarian Publishing, 2007.

Harris, Townsend. The Complete Journal of Townsend Harris First American Consul and Minister to Japan. Rutland, VT: C.E. Tuttle Co, 1959.

Harvey, William Hope. A Tale of Two Nations. Chicago, IL: Coin publishing Company, 1894.

Hauser, Elizabeth J. (Hg.). Tom L. Johnson: My Story. Kent, OH: Kent State University Press, 1993.

Hay, John Milton. The Bread-Winners: A Social Study. New York: Harper \& brothers, 1884.

Haywood, William Dudley und Bohn, Frank. Industrial Socialism. Chicago, IL: C. H. Kerr \& Company, Co-Operative, 1911.

Headley, Joel Tyler. The Great Riots of New York, 1712 to 1873: Including a Full and Complete Account of the Four Days' Draft Riot of 1863. New York: E. B. Treat, 1873.

Helbich, Wolfgang Johannes, Walter D. Kamphoefner und Ulrike Sommer. Briefe aus Amerika: Deutsche Auswanderer schreiben aus der Neuen Welt 1830-1930. München: C.H. Beck, 1988.

Henderson, Caroline A. und Turner, Alvin O. (Hg.). Letters from the Dust Bowl. Norman, OK: University of Oklahoma Press, 2001.

Henry, Alice, Stella M. Franklin, Amy Walker Field und Margaret Dreier Robins. Life and Labor. Chicago, IL: National Women's Trade Union League of America, 1911. 
Herbert Hoover Presidential Library and Museum. „Bricker Amendment Collection.“ [Web Page]: http://hoover.nara.gov/education/nhd/historydayBrickerAmend.html. Gesehen am 13.7.2015.

Hergesheimer, E. Map Showing the Distribution of the Slave Population of the Southern States of the United States Compiled from the Census of 1860. Sold for the Benefit of the Sick and Wounded Soldiers of the U. S. Army. [Washington, DC]: US Coast Guard, 1861.

Hietala, Thomas R. Manifest Design: American Exceptionalism and Empire. Ithaca, NY: Cornell University Press, 2003.

Hippisley, Alfred Edward. A Catalogue of the Hippisley Collection of Chinese Porcelains. Washington, DC: Selbstverlag, 1890.

Hippisley, Alfred Edward. A Sketch of the History of Ceramic Art in China with a Catalogue of the Hippisley Collection of Chinese Porcelains. Washington, DC: US National Museum, 1902.

Hobson, John Atkinson. The Psychology of Jingoism. London: G. Richards, 1901.

Hodgson, Godfrey. The Myth of American Exceptionalism. New Haven: Yale University Press, 2009.

Hoffman, Frederick Ludwig. Mortality from Respiratory Diseases in Dusty Trades (Inorganic Dusts). Washington, DC: Government Printing Office, 1918.

Hofstadter, Richard und Hofstadter, Beatrice K. (Hg.). Great Issues in American History from Reconstruction to the Present Day, 1864-1981. New York: Vintage Books, 1982.

Horsley, Albert E. The Confessions and Autobiography of Harry Orchard. New York: McClure, 1907.

Hosen, Frederick E. Federal Laws of the Reconstruction: Principal Congressional Acts and Resolutions, Presidential Proclamations, Speeches and Orders, and Other Legislative and Military Documents, 1862-1875. Jefferson, NC: McFarland \& Co, 2010.

Howard, Horatio P. A Self-Made Man, Capt. Paul Cuffee. [New York?: 1913?]

Hunt, James. „On Physio-Anthropology, Its Aim and Method.“ Journal of the Anthropological Society of London. 1867, 5:ccix-cclxx.

Hunter, Robert. Poverty. New York, London: The Macmillan Company. Macmillan \& Co., Itd, 1904.

Institut für Marxismus-Leninismus beim ZK der SED. Karl Marx, Friedrich Engels: Werke. Berlin: Dietz, 1956. 38 Bände.

Israel, Fred L. und McInerney, Thomas J. Presidential Documents: Words That Shaped a Nation from Washington to Obama. Routledge: New York, 2013.

James, William. Pragmatism: A New Name for Some Old Ways of Thinking. New York etc.: Longmans, Green, and Co, 1907.

Jordan, David Starr. The Blood of the Nation: A Study of the Decay of Races through Survival of the Unfit. Boston, MA: American Unitarian Association, 1902.

Jordan, David Starr. The Question of the Philippines: An Address Delivered before the Graduate Club of Leland Stanford Junior University, on February 14, 1899. Palo Alto, CA: Printed for the Graduate Club by the courtesy of J.J. Valentine, 1899.

Judson, Emily C. Allen Lucas: The Self-Made Man. Utica, NY: Bennett, Backus, \& Hawley, 1844. Kamphoefner, Walter D., Wolfgang Johannes Helbich und Ulrike Sommer. Briefe aus Amerika: News from the Land of Freedom. German Immigrants Write Home. Ithaca, NY: Cornell University Press, 1991. 
Kappler, Charles Joseph (Hg.). Indian Affairs: Laws and Treaties. Washington, DC: Government Printing Office, 1904.

Katzman, David M. und William M Tuttle. Plain Folk: The Life Stories of Undistinguished Americans. Urbana, IL: University of Illinois Press, 1982.

Kaufman, Stuart Bruce, Peter J. Albert, Grace Palladino, Marla J. Hughes und Mary C. Jeske (Hg.). The Samuel Gompers Papers. Urbana, IL: University of Illinois Press, 1986-2013. 13 Bände.

Kearney, Dennis. The Workingmen's Party of California: An Epitome of Its Rise and Progress. San Francisco: Bacon \& Co., printers, 1878.

Kelley, Florence. Our Toiling Children. Chicago, IL: Women's Temperance Publication Association, 1889.

Kelley, Florence. The Working Child. Chicago, IL: Wm. C. Hollister \& Bro., printers, 1896. Kelley, Florence, Kathryn Kish Sklar und Beverly Wilson Palmer. The Selected Letters of Florence Kelley, 1869-1931. Urbana, IL: University of Illinois Press, 2009.

Kingdom of Hawai'i. „Treaty of Reciprocity between the United States of America and the Hawai'ian Kingdom.“ [Web Page]: http://www.pixi.com/ kingdom/treaty1875.html. Gesehen am 13.7.2015.

Kingdom of Hawai'i. „Treaty with the Hawai'ian Islands, Dec. 20, 1849.“ [Web Page]: http:// www.pixi.com/ kingdom/treaty-1849.html. Gesehen am 13.7.2015.

Kipling, Rudyard. The White Man's Burden. London: s.n., 1899.

Kjellen, Rudolf. Die Großmächte der Gegenwart. Bremen: Dogma, 2012.

Kohut, Andrew, and Stokes, Bruce. America against the World: How We Are Different and Why We Are Disliked. New York: Times Books, 2006.

Kornbluh, Joyce L., Fred Thompson und Franklin Rosemont. Rebel Voices: An IWW Anthology. Oakland, CA: PM Press, 2011.

Kraus, Herbert. Die Monroedoktrin in ihren Beziehungen zur amerikanischen Diplomatie und zum Völkerrecht. Berlin: J. Guttentag, 1913.

Löwy, Bella. „The Russian Jews. Extermination or Emancipation?“ The Jewish Quarterly Review 6, no. 3 (1894):533-46.

Lansing, Robert. Pan-Americanism. Washington, DC: Government Printing Office, 1915.

Lathrop, Julia Clifford. The Children's Bureau. Chicago, IL: The University of Chicago press, 1912.

Lazarus, Emma. „The New Collossus.“ [Web Page]: http://www.loc.gov/exhibits/haventohome/ images/hh0041s.jpg. Gesehen am 13.7.2015.

Lehmkuhl, Ursula. „Auswandererbriefe aus Nordamerika.“ [Web Page]: http://www. auswandererbriefe.de/. Gesehen am 13.7.2015.

Lemkin, Raphael. Axis Rule in Occupied Europe: Laws of Occupation, Analysis of Government, Proposals for Redress. Washington, DC: Carnegie Endowment for International Peace, Division of International Law, 1944.

Leonard, Adna B. „Prospective Mission Fields.“ Gospel in All Lands 19, no. 8 (1898):363-64. Lincoln, Abraham. Lincoln Speeches. New York: Penguin Group, 2012.

Link, Arthur Stanley. The Papers of Woodrow Wilson. Princeton, NJ: Princeton University Press, $1966-1994$.

Linton, Eliza Lynne. „On the Side of the Maids.“ Cornhill Magazine 29 (1874):298-307.

Lippmann, Walter. Drift and Mastery. New York: M. Kennerley, 1914.

Lloyd, Henry Demarest. Lords of Industry. New York and London: G. P. Putnam's Sons, 1910. 
Lloyd, Henry Demarest. Wealth against Commonwealth. New York: Harper \& Brothers, 1894.

Lockwood, Lewis C. und Charlotte L. Forten. Two Black Teachers during the Civil War: Mary S.

Peake, The Colored Teacher at Fortress Monroe. New York: Arno Press, 1969.

Lodge, Henry Cabot. Speech by Henry Cabot Lodge on Immigration [Microform] Mr. Flint Presented the Following Speech on the Subject of Immigration Delivered by Hon. Henry Cabot Lodge, Before the Boston City Club, Boston, Mass., on March 20, 1908. Washington, D.C: G.P.O, 1908.

Lodge, Henry Cabot. Speeches and Addresses, 1884-1909. Boston: Houghton Mifflin, 1909.

Lodge, Henry Cabot und Theodore Roosevelt. Hero Tales from American History. New York: The Century Company, 1895.

Logan, Samuel Crothers. A City's Danger and Defense. Scranton, PA: J. B. Rodgers printing Co., 1887.

Lovejoy, Owen R. „The Extent of Child Labor in the Anthracite Coal Industry.“ Child Labor and the Republic. (Hg.) National Child Labor Committee, 35-49. New York: National Child Labor Committee, 1907.

Lum, Dyer D. A Concise History of the Great Trial of the Chicago Anarchists in 1886. Chicago, IL: Socialistic Publishing Company, 1886.

Lynch, John Roy. The Facts of Reconstruction. New York: The Neale Publishing Company, 1913.

MacGregor, Ford Herbert. Tenement House Legislation, State and Local. Madison, WI: Wisconsin library commission, 1909.

Mackinder, Halford John. Democratic Ideals and Reality: A Study in the Politics of Reconstruction. New York: H. Holt and Company, 1919.

Madsen, Deborah L. American Exceptionalism. Jackson: University Press of Mississippi, 1998. Maffly-Kipp, Laurie F. und Kathryn Lofton. Women's Work: An Anthology of African-American Women's Historical Writings from Antebellum America to the Harlem Renaissance. Oxford, New York: Oxford University Press, 2010.

Mahan, Alfred Thayer. The Influence of Sea Power upon History, 1660-1783. Boston, MA: Little, Brown \& Co., 1890.

Mahan, Alfred Thayer. Mahan on Naval Warfare: Selections from the Writing of Rear Admiral Alfred T. Mahan. Boston, MA: Little, Brown, 1918.

Marble, Manton. „Currency Quacks, and the Silver Bill.“ The North American Review 126, no. 260 (1878):156-70.

McClelland, Margaret Grenaway. A Self-Made Man. Philadelphia, PA: Lippincott Company, 1887.

McKenna, George. American Populism. New York: Putnam, 1974.

McLean, George N. The Rise and Fall of Anarchy in America from Its Incipient Stage of the First Bomb Thrown in Chicago: A Comprehensive Account of the Great Conspiracy Culminating in the Haymarket Massacre, May 4th, 1886. A Minute Account of the Apprehension, Trial, Conviction and Execution of the Leading Conspirators. Chicago, IL, Philadelphia, PA: R. G. Badoux \& Co, 1888.

McPherson, Edward. The Political History of the United States of America during the Period of Reconstruction (from April 15, 1865, to July 15, 1870). Washington, DC: Philp \& Solomons, 1871.

Mergenthaler, Ottmar. Catalogue A. Baltimore, MD: Selbstverlag, 1898.

Merrill, Walter McIntosh und Louis Ruchames. The Letters of William Lloyd Garrison. Cambridge, MA: Belknap Press of Harvard University Press, 1971-1981. 
Merritt, Walter Gordon. „The Law of the Danbury Hatters' Case.“ Annals of the American Academy of Political and Social Science 36, no. 2 (1910):11- 22.

Meyers, Christopher C. The Empire State of the South: Georgia History in Documents and Essays. Macon, GA: Mercer University Press, 2008.

Miller, Hunter (Hg.). Treaties and Other International Acts of the United States of America. 8 Bände. Washington, DC: Government Printing Office, 1931-1948.

Miller, Roger LeRoy und Frank B. Cross. The Legal Environment Today: Business in Its Ethical, Regulatory, E-Commerce, and International Setting. Mason, Ohio: Thomson/West, 2007.

Miller, Worth Robert. Populist Cartoons: An Illustrated History of the Third-Party Movement in the 1890s. Kirksville, MO: Truman State University Press, 2011.

Mississippi, Legislature, and Joint Special Committee on the Insurrection in Vicksburg, 1874. Report of the Joint Special Committee Appointed to Investigate the Late Insurrection in the City of Vicksburg, Warren County. Jackson, Miss: Pilot publishing Company, state printers, 1875.

Missouri Pacific Railway Company (1880-1909). Statistics and Information Concerning the Indian Territory Oklahoma, and the Cherokee Strip... With Compliments of the General Passenger Department of the Missouri Pacific Railway Co. St. Louis, MO: Woodward \& Tiernan, [1894?].

Moore, Frank (Hg.). Speeches of Andrew Johnson, President of the United States. Boston, MA: Little, Brown, and Company, 1865.

Moore, John Bassett. Henry Clay and Pan-Americanism. New York: Columbia University Press, 1915.

Morison, Elting Elmore, John Morton Blum und John J. Buckley. Letters. Cambridge, MA: Harvard University Press, 1951-1954.

Moro Province, Superintendent of Schools und Najeeb M. Saleeby. Magindanaw Reader, for the Public Schools of the Moro Province. Zamboanga: Mindanao herald press, 1905.

Moro Province, Superintendent of Schools und Najeeb M. Saleeby. Sulu Reader for the Public Schools of the Moro Province. Zamboanga, PI: Mindanao herald press, 1905.

Morrill, Justin Smith. Speech of Hon. Justin S. Morrill, of Vermont, on the Bill Granting Lands for Agricultural Colleges. Washington, DC: Congressional globe office, 1858.

National Archives and Records Administration. Records of the Field Offices for the State of Louisiana, Bureau of Refugees, Freedmen, and Abandoned Lands, 1863-1872.

Washington DC: U.S. Congress and National Archives and Records Administration, 2004.

National Child Labor Committee. Child Labor and the Republic. New York: National Child Labor Committee, 1907.

[National Union Republican Party]. Republican National Convention: Presidential Election, 1872. Proceedings of the National Union Republican Convention Held at Philadelphia, June 5 and 6, 1872. Washington, DC: Gibson Brothers, Printers, 1872.

Neihardt, John Gneisenau. Black Elk Speaks: The Complete Edition. Lincoln, NE: University of Nebraska Press, 2014.

Nelson A. Miles, Wade Hampton, Harry P. Robinson und Samuel Gompers. „The Lesson of the Recent Strikes.“ The North American Review 159, no. 453 (1894):180-206.

Nelson, Knute. „A Summary of Our Most Important Land Laws.“ Annals of the American Academy of Political and Social Science 33, no. 3 (1909):127-35.

New York, Legislature, Assembly und Special Committee on Railroads. Proceedings of the Special Committee on Railroads: Appointed Under a Resolution of the Assembly to 
Investigate Alleged Abuses in the Management of Railroads Chartered by the State of New York (1879). New York: Evening Post Steam Presses, 1879.

New York (State). The Tenement House Laws of the City of New York. The Tenement House Act. New York: The Tenement House Department, 1903.

Norris, Frank. The Octopus: A Story of California. Mineola, NY: Dover Publications, 2003.

Northern Illinois University. „Illinois during the Gilded Age.“ [Web Page]: http://gildedage.lib. niu.edu/islandora/object/niu-gildedage\%3 A24117. Gesehen am 13.7.2015.

Oklahoma Author's Club. The Romance of Oklahoma. Oklahoma City, OK: Oklahoma Author's Club, 1920.

Palmer, Beverly Wilson und Holly Byers Ochoa. The Selected Papers of Thaddeus Stevens. Pittsburgh, PA: University of Pittsburgh Press, 1997-1998.

Partido Revolucionario Cubano. Seccion Puerto Rico. Memoria de los Trabajos Realizados 1895 á 1898. New York City: Impr. A. W. Howes, 1898.

Partido Revolucionario Cubano. Sección Puerto Rico. Memoria de los Trabajos Realizados por la Sección Puerto Rico del Partido Revolucionario Cubano. New York City: Impr. de A. W. Howes, 1898.

Paxson, Frederic L. The Last American Frontier. New York: Macmillan, 1910.

Pease, Donald E. The New American Exceptionalism. Minneapolis: University of Minnesota Press, 2009.

Pease, Verne S. In the Wake of War: A Tale of the South under Carpet-Bagger Administration. Chicago, New York: G. M. Hill Company, 1900.

Peffer, William Alfred. The Farmer's Side: His Troubles and Their Remedy. New York: D. Appleton and Company, 1891.

Peirce, E. D. Five Lectures Upon the Cause, Prevention, and Cure of Disease, the Mysteries and Fallacies of the Faculty, and upon the Origin, Design, Benefit and Phenomena of Animal Magnetism with an Appendix, Containing Many Interesting Facts on Magnetism or Mesmerism, and Clairvoyance: Directions for Using the Magnetic Machine in Various Chronic Complaints: The Recipes for Making Their Appropriate Medicines, the Mode of Giving It, Miscellaneous Remarks, \&c. \&c. Rochester, NY: Rochester Daily Advertiser Book \& Job Office, 1847.

Perry, Matthew Calbraith. Narrative of the Expedition of an American Squadron to the China Seas and Japan, Performed in the Years 1852, 1853 and 1854, Under the Command of Commodore M. C. Perry, United States Navy. Washington, DC: A. O. P. Nicholson, printer, 1856.

Pierce, Edward Lillie. A Diplomatic Fiasco: The Rejected Treaty for St. Thomas. Boston, MA: R. F. Wallcut, 1889.

Pierce, Edward Lillie. The Negroes at Port Royal: Report of E. L. Pierce, Government Agent, to the Hon. Salmon P. Chase, Secretary of the Treasury. Boston, MA: R. F. Wallcut, 1862.

Pike, James Shepherd. The Prostrate State: South Carolina under Negro Government. New York: D. Appleton, 1874.

Pinkerton, Allan. Strikers, Communists, Tramps and Detectives. New York: G. W. Carleton \& Co, 1878.

Poliakov, Léon. The History of Anti-Semitism. London: Routledge \& Kegan Paul, 1974-1985.

Porterfield, Jason. The Homestead Act of 1862: A Primary Source History of the Settlement of the American Heartland in the Late 19th Century. New York: Rosen Pub. Group, 2005. 
Powderly, Terence Vincent. „Immigration's Menace to the National Health.“ The North American Review 175, no. 548 (1902):53-60.

Powderly, Terence Vincent. Thirty Years of Labor, 1859-1889. New York: A. M. Kelley, 1967. Pugh, Evan. A Report Upon a Plan for the Organization of Colleges for Agriculture and the Mechanic Arts with Special Reference to the Organization of the Agricultural College of Pennsylvania, in View of the Endowment of This Institution by the Land Scrip Fund, Donated by Congress to the State of Pennsylvania, Addressed to the Board of Trustees of the Agricultural College of Pennsylvania, Convened at Harrisburg, January 6, 1864. Harrisburg, PA: Singerly \& Myers, printers, 1864.

Rauschenbusch, Walter. Christianity and the Social Crisis. New York: Macmillan Co, 1907.

Rauschenbusch, Walter. A Theology for the Social Gospel. New York: The Macmillan Company, 1917.

Reef, Catherine. Working in America. New York: Facts on File, 2007.

Reichskommission in Chicago, 1893. Amtlicher Bericht über die Weltausstellung in Chicago 1893. Berlin: Reichsdruckerei, 1894.

Reid, Whitelaw. After the War: A Southern Tour. May 1, 1865, to May 1, 1866. Cincinnati, OH, New York: Moore, Wilstach \& Baldwin, etc., etc., 1866.

Reid, Whitelaw. „The Territory with Which We Are Threatened.“ The Century: A Popular Quarterly 56, no. 5 (1898):788-94.

Resident of Utah. Utah and Statehood: Objections Considered, Simple Facts Plainly Told. With a Brief Synopsis of the State Constitution. New York: Printed for the author by Hart \& Von Arx, 1888.

Reyes y Florentino, Isabelo de los. La Religion del „Katipunan“. Madrid: Tipolit. de J. Corrales, 1900.

Rice, Clinton. The New Territorial Government of the District of Columbia under the Act of Congress Entitled „An Act to Provide a Government for the District of Columbia,“ Approved February 21, A. D. 1871. Washington, DC: Philp \& Solomons, 1871.

Riis, Jacob A. How the Other Half Lives: Studies Among the Tenements of New York. New York: Charles Scribner's Sons, 1890.

Ringwalt, John Luther. Development of Transportation Systems in the United States. Philadelphia, PA: Railway World Office, 1888.

Riordon, William L. Plunkitt of Tammany Hall: A Series of Very Plain Talks on Very Practical Politics. New York: Signet Classic, 1996.

Rizal y Alonzo, José. Noli Me Tangere. Berlin: Berliner Buchdruckerei-Actien-Gesellschaft, 1886.

Robinson, John R. The Octopus: A History of the Construction, Conspiracies, Extortions, Robberies, and Villainous Acts of the Central Pacific, Southern Pacific of Kentucky, Union Pacific, and Other Subsidized Railroads. San Francisco, CA: Eigenverlag, 1894.

Roosevelt, Theodore. Address of Hon. Theodore Roosevelt Before the Naval War College, Newport, R.I., Wednesday, June 2, 1897. Washington: Navy Branch, Govt. Print. Off, 1897. Roosevelt, Theodore. Letters. Cambridge, MA: Harvard University Press, 1951-1954. Roosevelt, Theodore. The Naval War of 1812. New York: G. P. Putnam's sons, 1882. Roosevelt, Theodore. The Rough Riders. New York: C. Scribner's Sons, 1899.

Roosevelt, Theodore. Theodore Roosevelt: An Autobiography. New York: The Macmillan Company, 1913. 
Roosevelt, Theodore. The Winning of the West: An Account of the Exploration and Settlement of Our Country from the Alleghanies to the Pacific. New York: G. P. Putnam's sons, 1889-1896. 4 Bände.

Roosevelt, Theodore. The Works of Theodore Roosevelt. New York: Collier and Son, 1900. 14 Bände.

Ross, Edward A. „The Causes of Race Superiority.“ Annals of the American Academy of Political and Social Science 18, no. July 1 (1901):67-89.

Ross, William Potter. Indian Territory: Remarks in Opposition to the Bill to Organize the Territory of Oklahoma before the Committee on Territories of the House of Representatives, February 9th, 1874. Washington, DC: Gibson Bros., printers, 1874.

Ruiz Leyn, José. Los Filibusteros en Madrid y el Apresamiento del „Virginius.“ Madrid: Impr. de T. Fortanet, 1874.

Ryan, Frank X. Darwin's Impact: Social Evolution in America, 1880-1920. Bristol: Thoemmes Press, 2001.

Samito, Christian G. Changes in Law and Society during the Civil War and Reconstruction: A Legal History Documentary Reader. Carbondale, IL: Southern Illinois University Press, 2009.

San Francisco [City and County]. The Building Law of the City and County of San Francisco: Bill. No. 1121. Ordinance No. 1008. The State Tenement House Act. Ordinance No. 746. Regulating the Construction of Buildings Used as Automobile Garages. San Francisco: Daily Pacific Builder, 1910.

Sandino, Augusto César. Sandino Without Frontiers: Selected Writings of Augusto Сйsar Sandino on Internationalism, Pan-Americanism, and Social Questions. Hampton, VA: Compita Pub, 1988.

Sargent, Charles S. „The Protection of Forests.“ The North American Review 135, no. 311 (1882):386- 401.

Schaack, Michael J. Anarchy and Anarchists: A History of the Red Terror and the Social Revolution in America and Europe. Communism, Socialism, and Nihilism in Doctrine and in Deed. The Chicago Haymarket Conspiracy and the Detection and Trial of the Conspirators. Chicago, IL, New York, Philadelphia, PA, St. Louis, MO, Pittsburg, PA: F. J. Schulte \& Company. W.A. Houghton. S.F. Junkin \& Co. P.J. Fleming \& Co, 1889.

Schurz, Carl. Annexation of San Domingo. Washington: F. \& J. Rives. G. A. Bailey, Printers, 1871.

Schurz, Carl. Speeches, Correspondence and Political Papers of Carl Schurz. New York: G.P. Putnam's Sons, 1913.

Scruggs, William Lindsay. British Aggressions in Venezuela or, The Monroe Doctrine on Trial. Atlanta, Ga: The Franklin printing and publishing Co., 1895.

Search, Theodore C. „Our Trade with South America.“ The North American Review 163, no. 481 (1896): $716-24$.

Seymour, Charles C. B. Self-Made Men. New York: Harper \& bros, 1858.

Shafer, Byron E. Is America Different? A New Look at American Exceptionalism. Oxford, New York: Clarendon Press. Oxford University Press, 1991.

Sheldon, Charles Monroe. In His Steps „What Would Jesus Do?“ Chicago, IL: Advance Publishing Co, 1897.

Sherman, William T. Memoirs of General W.T. Sherman. New York: Library of America. Distributed to the trade in the U.S. and Canada by Viking Press, 1990. 
Sherrill, Charles Hitchcock. The Pan-Americanism of Henry Clay, Sarmiento and Root. Buenos Aires: J. Grant \& son, printers, 1909.

Sibley, John Langdon und John Hopkins Morison. A Remarkable Self-Made Man. Cambridge MA: J. Wilson and sons, 1886.

Silagi, Michael. Henry George und Europa: Zur Entstehungsgeschichte der europäischen Bodenreformbewegungen. München: Etana, 1973.

Sinclair, Upton. The Jungle. Harmondsworth: Penguin, 1974.

Skipp, Francis E. (Hg.). The Complete Short Stories of Thomas Wolfe. New York: Scribner, 1987. Smith, Adam. Wealth of Nations. New York: Cosimo, 2007.

Smith, Jean. „Frankie Mae.“ Negro Digest 17, no. 8 (1968):84-90.

Smith, L. M. The Great American Crisis or, Cause and Cure of the Rebellion: Embracing Phrenological Characters and Pen-and-Ink Portraits of the President, His Leading Generals and Cabinet Officers. Cincinnati, OH: Johnson, Stephens \& Co., printers, 1862.

Smith, Steven B, Danilo Petranovic, Ralph Lerner und Benjamin A. Kleinerman (Hg.). The Writings of Abraham Lincoln. New Haven, CT, London: Yale University Press, 2012.

Socialist Labor Party. Proceedings of the National Convention Held in Chicago, September 28, 1889. Cinncinati, OH: J. Willig, 1889.

Socialist Labor Party. Proceedings of the National Convention of the Socialist Labor Party Held at Turner Hall, Allegheny City, PA, Commencing Dec. 26th, 1879. Detroit, MI: National Executive Committee of the Socialist Labor Party, 1880.

Söderlind, Sylvia und Carson, James Taylor. American Exceptionalisms from Winthrop to Winfrey. Albany: State University of New York Press, 2011.

Sombart, Werner. Warum gibt es in den Vereinigten Staaten keinen Sozialismus? Tübingen: J.C.B. Mohr (P. Siebeck), 1906.

Speer, William S. The Encyclopedia of the New West: Containing Fully Authenticated Information of the Agricultural, Mercantile, Commercial, Manufacturing, Mining and Grazing Industries, and Representing the Character, Development, Resources and Present Condition of Texas, Arkansas, Colorado, New Mexico and Indian Territory. Also, Biographical Sketches of Their Representative Men and Women. Marshall, TX: The United States biographical publishing Company, 1881.

Spies, August Vincent Theodore. The Accused, the Accusers. Chicago, IL: Socialistic publishing society, [1886?].

Spies, August Vincent Theodore und Albert R. Parsons. The Great Anarchist Trial: The Haymarket Speeches as Delivered on the Evening of the Throwing of the Bomb at Haymarket Square, Chicago, May 4, 1886. Chicago, IL: The Chicago labor press association, 1886.

Sprague, C. P., and H. W. Atwell. The Western Shore Gazetteer and Commercial Directory, for the State of California Containing the Names of All the Adult Male Citizens of the State [...] Yolo County. Woodland, CA: C.P. Sprague \& H.W. Atwell, 1870.

St. Clair, Francis. The Katipunan: The Rise and Fall of the Filipino Commune. Manila: Amigos del Pais, 1902.

St. Louis Merchants' Exchange, George Hagar Morgan und Smith, Eugene. Annual Statement of the Trade and Commerce of Saint Louis. St. Louis, MO: Press of R. P. Studley \& Co., $1866-1919$.

Stanwood, Edward. A History of the Presidency from 1897 to 1909. Boston and New York: Houghton Mifflin Company, 1912. 
Stead, William Thomas. If Christ Came to Chicago! A Plea for the Union of All Who Love in the Service of All Who Suffer. London: Pub. at the office of „The Review of Reviews“, 1894. Steffens, Lincoln. The Shame of the Cities. New York: McClure, Phillips \& Co, 1904. Stein, Leon und Philip Taft. Workers Speak: Self Portraits. New York: Arno, 1971. Stephens, Alexander Hamilton. A Constitutional View of the Late War Between the States, Its Causes, Character, Conduct and Results, Presented in a Series of Colloquies at Liberty Hall. Philadelphia, PA: National Publishing Company, 1868-1970.

Stevens, Thaddeus. Speech of Hon. T. Stevens, of Pennsylvania, Delivered in the House of Representatives, March 19, 1867 on the Bill (H.R. no. 20) Relative to Damages to Loyal Men, and for Other Purposes. Washington, DC: Republican Congressional Executive Committee, 1867.

Stimson, Henry L. American Policy in Nicaragua. New York: C. Scribner’s sons, 1927.

Storey, Moorfield und Julian Codman. Secretary Root's Record: „Marked Severities“ in Philippine Warfare: An Analysis of the Law and Facts Bearing on the Action and Utterances of President Roosevelt and Secretary Root. Boston, MA: G.H. Ellis Co., printers, 1902.

Stowe, Harriet Beecher, Charles Edward Stowe und Kirk Munroe. The Lives and Deeds of Our Self-Made Men. Boston, MA: Estes and Lauriat, 1889.

Stowell, Myron R. „Fort Frick“, Or, The Siege of Homestead: A History of the Famous Battle Between the Amalgamated Association of Iron and Steel Workers and the Carnegie Steel Company (Limited) of Pittsburgh. Pittsburg, PA: Pittsburg printing Co., 1893.

Strong, Josiah. Our Country: Its Possible Future and Its Present Crisis. New York: Baker \& Taylor for the American Home Missionary Society, 1885.

Strong, Josiah. Unser Land, dessen mögliche Zukunft und gegenwärtige Crisis. Cleveland, $\mathrm{OH}$ : Ohio, Lauer \& Mattill, 1891.

Suffragists Oral History Project. „The Suffragists: From Tea-Parties to Prison.“ [Web Page]: http://www.oac.cdlib.org/view?docld=kt2 h4n992z\&chunk.id=tpage\&brand=oac4\&doc. view=entire_text. Gesehen am 13.7.2015.

Sumner, Charles. Naboth's Vineyard Speech. Washington, DC: F. \& J. Rives \& G. A. Bailey, Printers, 1870.

Sumner, Charles. Speech of Hon. Charles Sumner, of Massachusetts, on the Cession of Russian America to the United States. Washington, DC: Printed at the Congressional Globe Office, 1867.

Sumner, Charles. The Works of Charles Sumner. Boston, MA: Lee and Shepard, 1870-1983.

Sumner, Charles. What Social Classes Owe to Each Other. New York: Harper \& brothers, 1883.

Sumner, Charles. What Social Classes Owe to Each Other. New Haven: Yale University Press, 1925.

Sweet, J. P. „A Day on Coney Island“: Containing a Description of That Celebrated Watering Place, Its Geological Formation and Social History, With a Graphic Description of Its Magnificent Surroundings, As Viewed from the Great Iron Observatory; Containing, Also, an Account of the ,Dream ' of A.T. Stewart, in Which He Endeavors to Extend His Financial Operations to Our Dreamy Satellite; Also, His Introduction to Several Distinguished Lunarians; the Work Concludes With a Brief Description of the Principal Hotels at Coney Island and Finally Foreshadows the Ultimate Submersion of This Lovely Island Beneath the Frozen Waters of the Ocean; in Heroic Verse. New York: Printing House of H.T. Cornett, 1880. 
Swinton, John. A Momentous Question: The Respective Attitudes of Labor and Capital. Philadelphia, PA: Keller, 1895.

Swinton, John. Striking for Life: Labor's Side of the Labor Question. The Right of the Workingman to a Fair Living. Evansville, IN: Keller, 1894.

Sylvis, James C. (Hg.). The Life, Speeches, Labors and Essays of William H. Sylvis: Late President of the Iron-Moulders' International Union, and also of the National Labor Union. Philadelphia, PA: Claxton, Remsen \& Haffelfinger, 1872.

Tappan, Eva March, Karl Julius Ploetz, William H Tillinghast und Horatio W Dresser. The World's Story: A History of the World in Story, Song and Art. Boston, MA, New York: Houghton Mifflin Company, 1914.

Tarbell, Ida M. The History of the Standard Oil Company. New York: McClure, Phillips \& Co., 1904.

Tarbell, Ida M. und David Mark Chalmers. The History of the Standard Oil Company. New York: Harper \& Row, 1966.

Taylor, Frederick Winslow. The Principles of Scientific Management. New York, London: Harper \& Brothers, 1911.

Taylor, Frederick Winslow. The Principles of Scientific Management. New York, London: Harper \& Brothers, 1911.

Taylor, Frederick Winslow. Shop Management: A Paper Read Before the American Society of Mechanical Engineers. New York: 1903.

Thayer, William Roscoe. The Life and Letters of John Hay. Boston and New York: Houghton Mifflin Company, 1915.

The Library of Congress. „A Century of Law Making for a New Nation: U.S. Congressional Documents and Debates, 1774-1875.“ [Web Page]: http://memory.loc.gov/cgi-bin/ ampage?collld=llac\&fileName=041/llac041.db\&recNum=393. Gesehen am 13.7.2015.

The Maritime Canal Company of Nicaragua. Certificate of Incorporation and Other Documents. New York: C. G. Burgoyne, 1889.

Thomas, John Jacob. Farm Implements and Farm Machinery. New York: O. Judd Company, 1886. Thompson, C. Mildred. Reconstruction in Georgia: Economic, Social, Political, 1865-1872. New York: Columbia University Press, 1915.

Tiedeman, Christopher Gustavus. A Treatise on State and Federal Control of Persons and Property in the United States Considered from Both a Civil and Criminal Standpoint. St. Louis, MO: The F. H. Thomas Law Book Co, 1900. 2 Bände.

Tolman, William Howe. Social Engineering: A Record of Things Done by American Industrialists Employing Upwards of One and One-Half Million of People. New York: McGraw publishing Company, 1909.

Trent, Logan Douglas. The Credit Mobilier. New York: Arno Press, 1981.

Trumbull, Lyman. Speech of Hon. Lyman Trumbull of Illinois on the Freedmen's Bureau, Delivered in the Senate of the United States, February 20, 1866. Washington, DC: Chronicle Book and Job Print, 1866.

Turner, Frederick Jackson. The Significance of the Frontier in American History. Madison, WI: State Historical Society of Wisconsin, 1894.

Twain, Mark. Following the Equator and Anti-Imperialist Essays. New York: Oxford University Press, 2010.

Twain, Mark und Warner, Charles Dudley. The Gilded Age: A Tale of to-Day. Hartford, CT: American Pub. Co, 1873. 
United Nations. „Convention on the Prevention and Punishment of the Crime of Genocide.“ [Web Page]: http://www.hrweb.org/legal/genocide.html. Gesehen am 9.7.2015.

United States. The Public Statutes at Large of the United States of America. Boston, MA: Charles C. Little and James Brown, 1845.

United States. The Statutes at Large: Treaties, and Proclamations of the United States of America. Boston, MA: Little \& Brown, 1868.

United States und Bureau of Corporations. The Lumber Industry. New York: Arno Press, 1972.

United States und Bureau of the Census. Population Profile of the United States. Washington, DC: US Dept. of Commerce, Bureau of the Census, 1999.

United States und Bureau of the Census. Statistics of Women at Work. Washington, DC: Government Printing Office, 1907.

United States und Bureau of the Census. Population Profile of the United States. Washington, DC: U.S. Dept. of Commerce, Bureau of the Census, 2000.

United States und Census Office. Population of the United States by States and Territories, Counties, and Minor Civil Divisions, as Returned at the Twelfth Census: 1900. Washington, DC: United States Census Printing Office, 1901.

United States und Congress. The Congressional Globe. Washington, DC: Blair \& Rives, $1834-1873$.

United States, Congress, House und Committee on Banking and Currency. Money Trust Investigation: Investigation of Financial and Monetary Conditions in the United States under House Resolutions Nos. 429 and 504, before a Subcommittee of the Committee on Banking and Currency. Interlocking Directorates. Washington, DC: Government Printing Office, 1913.

United States, Congress, House und Committee on the Judiciary. Investigation of the Employment of Pinkerton Detectives in Connection with the Labor Troubles at Homestead, Pa. Washington, DC: Government Printing Office, 1892.

United States, Congress, House und Committee on the Judiciary. Hearings Before the Committee on the Judiciary, House of Representatives, Sixty-Fourth Congress, First[-Second] Session. Washington: G.P.O, 1917.

United States, Congress und House of Representatives. Investigation of United States Steel Corporation: Report No. 1127. Washington, DC: Government Printing Office, 1912.

United States, Congress und House of Representatives. Reports of Committees of the House of Representatives for the Second Session of the Forty-Second Congress in Four Volumes. Washington, DC: Government Printing Office, 1872.

United States, Congress und House of Representatives. United States Congressional Serial Set, 108th Congress, Serial No. 14829, House Documents No. 67-95. Washington DC: Government Printing Office, 2004.

United States, Congress und Joint Committee on the Conduct of the War. Report of the Joint Committee on the Conduct of the War. Wilmington, NC: Broadfoot Pub. Co, 1998-.

United States, Congress und Joint Committee on the Conduct of the War. Report of the Joint Committee on the Conduct of the War at the Second Session, 38th Congress. Washington, DC: Government Printing Office, 1865.

United States, Congress, und Joint Select Committee on the Condition of Affairs in the Late Insurrectionary States. Report of the Joint Select Committee Appointed to Inquire into the Condition of Affairs in the Late Insurrectionary States, So Far as Regards the Execution of 
Laws, and the Safety of the Lives and Property of the Citizens of the United States and Testimony Taken. Washington, DC: Government Printing Office, 1872.

United States, Congress und Senate. Index to the Reports of the Committees of the Senate of the United States for the Second Session of the Forty-Second Congress, 1871-72 in Four Volumes. Washington, DC: Government Printing Office, 1872.

United States, Congress und Senate. Laws in Relation to Freedmen Compiled by Command of Major General 0.0. Howard, Commissioner, Bureau of Refugees, Freedmen and Abandoned Lands, in: Executive Documents: 39th Congress, 2nd Session. Washington, DC: Government Printing Office, 1867.

United States, Congress, Senate und Committee on Education and Labor. Investigation of Strike in Steel Industries: Hearings Before the Committee on Education and Labor, United States Senate, Sixty-Sixth Congress, First Session, Pursuant to S. Res. 202. Washington DC: Govt. Print. Off, 1919.

United States, Congress, Senate, Committee on Education and Labor und William Squire Kenyon. Investigating Strike in Steel Industries Report. 〈Pursuant to S. Res. 188>. Washington, DC: Government Printing Office, 1919.

United States, Congress, Senate und Select Committee on Interstate Commerce. Report of the Senate Select Committee on Interstate Commerce (With Appendix). Forty-Ninth Congress, First Session. Submitted to the Senate January 18, 1886. Washington, DC: Government Printing Office, 1886.

United States, Congress, Senate und Select Committee to Inquire into the Mississippi Election of 1875. Mississippi in 1875: Report of the Select Committee to Inquire into the Mississippi Election of 1875, With the Testimony and Documentary Evidence. Washington, DC: Government Printing Office, 1876.

United States, Congress, Senate und Select Committee to Investigate Alleged Outrages in the Southern States. Report on the Alleged Outrages in the Southern States. Washington, DC: Government Printing Office, 1871.

United States und Department of Agriculture. List of Agricultural Colleges and of Farmers' Clubs, and Agricultural, Horticultural, and Pomological Societies on the Books of the Department of Agriculture, June 1, 1872, together with the Name of the President and Secretary of Each. Washington, DC: Government Printing Office, 1872.

United States und Department of Agriculture. List of Agricultural Societies and Farmers' Clubs Established to Promote the Agricultural, Horticultural, and Pomological Interests of the Farmer, on the Books of the Department of Agriculture, July 4, 1876, Being the Centennial Year of American Independence, together with a List of Agricultural Colleges. Washington, DC: Government Printing Office, 1876.

United States, Department of Agriculture und Office of Experiment Stations. Organization Lists of the Agricultural Colleges and Experiment Stations in the United States, 1889, 1892 -1912. Washington, DC: Government Printing Office, 1889-1913. 24 Bände.

United States, Department of Commerce und Bureau of the Census. Historical Statistics of the United States: Colonial Times to 1970, 2 Vols. White Plains NY: Kraus International Publications, 1989.

United States, Department of Commerce und United States Census Bureau. „Historical Census of Housing Tables.“ [Web Page]: https://www.census.gov/hhes/www/housing/census/ historic/owner.html. Gesehen am 13.7.2015. 
United States und Department of Labor Statistics. „Consumer Price Index Data from 1913 to 2013.“ [Web Page]: http://www.usinflationcalculator.com/inflation/consumer-price-indexand-annual-percent-changes-from-1913-to-2008/. Gesehen am 13.7.2015.

United States und Utah Commission. Utah Statehood: Reasons Why It Should Not Be Granted. Salt Lake City, UT: Tribune print, 1887.

United States und Department of State. Message of the President Relating to the Steamer Virginius, with the Accompanying Documents, Transmitted to Congress, January 5, 1874. Washington: G.P.O, 1874.

United States und Department of State. Papers Relating to the Foreign Relations of the United States: 1898. Washington, DC: Government Printing Office, 1901.

United States und Department of the Interior. Message from the President of the United States Transmitting Letter of the Secretary of the Interior Relative to Pending Legislation Providing for the Opening Up to Settlement of Certain Lands in the Indian Territory. Washington, DC: Government Printing Office, 1885.

United States und Dept. of Agriculture. Persons Employed in Meat Inspection. Washington, DC: Government Printing Office, 1907.

United States, Dept. of Agriculture, United States und Bureau of Animal Industry. Regulations Governing the Meat Inspection of the United States Department of Agriculture as Amended, Effective May 1, 1908. Washington, DC: Government Printing Office, 1908.

United States, Electoral Commission (1877) und Congress. Electoral Count of 1877: Proceedings of the Electoral Commission and of the Two Houses of Congress in Joint Meeting Relative to the Count of Electoral Votes Cast December 6, 1876, for the Presidential Term Commencing March 4, 1877. Washington, DC: Government Printing Office, 1877.

United States und Geneva Arbitration Tribunal. Argument of the United States, Delivered to the Tribunal of Arbitration at Geneva, June 15, 1872. Paris: Dubuisson \& Co., 1872.

United States und Geneva Arbitration Tribunal. Réclamations de l’Alabama. Paris: Impr. de Dubuisson, etc, 1871-1972.

United States. Industrial Commission. Report of the Industrial Commission on Agriculture and Agricultural Labor, Including Testimony with Review and Topical Digest Thereof. Washington, DC: Government Printing Office, 1901.

United States. Patent Office. Improvement in Type-Writing Machines: US207559 A. 27. August 1878.

United States. Philippine Commission. Report of the Philippine Commission to the Secretary of War 1900-1915. Washington, DC: Government Printing Office, 1901ff. 32 Bände.

United States. President. A Compilation of the Messages and Papers of the Presidents Prepared Under the Direction of the Joint Committee on Printing, of the House and Senate, Pursuant to an Act of the Fifty-Second Congress of the United States. New York: Bureau of National Literature, 1914.

United States. President. Department of State. State Papers and Publick [sic] Documents of the United States, from the Accession of George Washington to the Presidency Exhibiting a Complete View of Our Foreign Relations since That Time. Boston, MA: Printed and Published by Thomas B. Wait, 1819, 12 Bände.

United States. President. Message of the President of the United States Respecting the Relations with Chile. Washington, DC: Government Printing Office, 1892. 
United States, Rhode Island. General Assembly. Act of Congress, Granting Lands for the Establishing of Agricultural Colleges. Providence, RI: A. Anthony, printer to the state, 1863.

United States. Supreme Court. Reports of Cases Argued and Adjudged in the Supreme Court of the United States. Washington, DC: Published for John Conrad and Co, 1804-1862.

United States. Supreme Court. Cases Argued and Adjudged in the Supreme Court of the United States. Washington, DC: W.H. \& O.H. Morrison, 1866-1874.

United States. War Department. The War of the Rebellion: A Compilation of the Official Records of the Union and Confederate Armies. Washington, DC: Government Printing Office, $1880-1901$.

United States. War Department und Lieber, Francis. Instructions for the Government of Armies of the United States in the Field. Washington: G.P.O. 1898.

United States. Strike Commission. Report on the Chicago Strike of June-July, 1894. Washington DC: Government Printing Office, 1895.

University of California at Santa Barbara. The American Presidency Project [Web Page]: http:// www.presidency.ucsb.edu. Gesehen am 9.7.2015.

University of California. College of Agriculture. Agricultural Experiment Station. „Announcements of Farmers' Short Courses for 1912 at the University Farm, Davis, California.“ Circular No. 78 (Juni 1912).

Van Doren, Carl (Hg.). The Literary Works of Abraham Lincoln. Norwalk, CT: Easton Press, 1980.

Varona, Enrique José. Cuba Contra Espana: Manifiesto del Partido Revolucionario Cubano a los Pueblos Hispano-Americanos. New York: S. Figueroa, 1895.

Veblen, Thorstein. The Theory of the Leisure Class: An Economic Study in the Evolution of Institutions. New York, London: The Macmillan Company, 1899.

Veiller, Lawrence. Tenement House Commission [of the State New York]. Tenement House Legislation in New York 1852-1900. Albany, NY: Brandow, 1900.

Vincent, Leopold. The Alliance and Labor Songster. Winfield, KS: H. \& L. Vincent, printers, 1890.

Vincent, Leopold. The Alliance and Labor Songster: A Collection of Labor and Comic Songs for the Use of Alliances, Grange Debating Clubs and Political Gatherings. Winfield, KS: W. \& L. Vincent, 1891.

Voss-Hubbard, Mark. Illinois's War: The Civil War in Documents. Athens, $\mathrm{OH}$ : Ohio University Press, 2013.

Walker, A. J. The Revised Code of Alabama. Montgomery, AL: Reid \& Screws, 1867.

Walker, Jeanie Mort. Life of Capt. Joseph Fry, the Cuban Martyr. Hartford: J. B. Burr publishing Co., 1874.

Walker, John Brisben und Bridge, James Howard. The History of the World's Largest Corporation. New York: The Aldine book company, 1903?

Warburg, Paul M. „Defects and Needs of Our Banking System.“ Proceedings of the Academy of Political Science in the City of New York 4, no. 4 (1914):7-22.

Ward, Lester Frank. Dynamic Sociology. New York: D. Appleton and company, 1883.

Warmoth, Henry Clay. War, Politics, and Reconstruction: Stormy Days in Louisiana. Columbia, SC: University of South Carolina Press, 2006.

Warner, Amos Griswold. American Charities: A Study in Philanthropy and Economics. New York, Boston, MA: T. Y. Crowell \& Co., 1894. 
Washington, George. „Farewell Address to the People of the United States.“ The Independent Chronicle (1796).

Welky, David. America between the Wars, 1919-1941: A Documentary Reader. Malden, MA: Wiley-Blackwell, 2012.

Wheeler, Noyes. The Phrenological Characters and Talents of Henry Clay, Daniel Webster, John Quincy Adams, William Henry Harrison, and Andrew Jackson. Boston, MA: Dow \& Jackson, 1844.

Wiley, Harvey Washington. Chemistry and Longevity: Food in Its Relation to Individual and National Development. New York: Hundred Year Club, 1900.

Willard, Frances E. Do Everything: A Handbook for the World's White Ribboners. Chicago, IL: The Woman's temperance publishing association, 1895.

Williams, Charles Richard (Hg.). Diary and Letters of Rutherford Birchard Hayes. Columbus, $\mathrm{OH}$ : The Ohio State Archæological and Historical Society, 1922.

Wilson, Henry. History of the Reconstruction Measures of the Thirty-Ninth and Fortieth Congresses. Hartford, CT, Chicago, IL: Hartford Publishing Company. J. A. Stoddard, etc., etc., 1868.

Wilson, William Dexter. Attainder of Treason and Confiscation of the Property of Rebels: A Letter to the Hon. Samuel A. Foot, LL. D., on the Constitutional Restrictions upon Attainder and Forfeiture for Treason against the United States. Albany, NY: Weed, Parsons and Company, Printers, 1863.

Wister, Owen. Red Men and White. New York: Harper, 1896.

Wister, Owen. Ulysses S. Grant. Boston: Small, Maynard, 1901.

Wister, Owen. The Virginian a Horseman of the Plains. New York: Grosset \& Dunlap, 1925.

Wood, Charles Erskine Scott. Heavenly Discourse. New York: Vanguard press, The New Masses, 1927.

Woods, William Allan. „Injunction in the Federal Courts.“ Yale Law Journal 6, no. 5 (1897):245-51.

Wooley, John and Peters, Gerhard. „Voter Turnout in Presidential Elections: 1828-2008.“ [Web Page]: http://www.presidency.ucsb.edu/data/turnout.php. Gesehen am 13.7.2015.

Wright, Marcus J. Wright's Official History of the Spanish-American War. Washington, DC: War Records Office, 1900.

Zaide, Gregorio F. und Zaide, Sonia M.. Documentary Sources of Philippine History. Metro Manila, Philippines: National Book Store, 1990.

\subsection{Sekundärliteratur}

Abadinsky, Howard. Organized Crime. Wadsworth, OH: Cengage Learning, 2012.

Abbott, Martin Linton. „Free Land, Free Labor, and the Freedmen's Bureau.“ Agricultural History 30, no. 4 (1956):150-156.

Abbott, Martin Linton. The Freedmen's Bureau in South Carolina, 1865-1872. Chapel Hill, NC: University of North Carolina Press, 1967.

Abbott, Richard H. The Republican Party and the South, 1855-1877: The First Southern Strategy. Chapel Hill, NC: University of North Carolina Press, 1986. 
Ackerman, Kenneth D. Boss Tweed the Rise and Fall of the Corrupt Pol Who Conceived the Soul of Modern New York. New York, Berkeley, CA: Carroll \& Graf Publishers. Distributed by Publishers Group West, 2005.

Ackermann, Rolf. Pfadabhängigkeit, Institutionen und Regelreform. Tübingen: Mohr Siebeck, 2001.

Adams, John Quincy. „John Quincy Adams's Account of the Cabinet Meeting of November 7, 1823.“ [Web Page]: http://www.mtholyoke.edu/acad/intrel/jqacab.htm. Gesehen am 9.7.2015.

Adams, Judith A. The American Amusement Park Industry: A History of Technology and Thrills. Boston, MA: Twayne Publishers, 1991.

Adams, Pauline und Thornton, Emma S. A Populist Assault: Sarah E. Van De Vort Emery on American Democracy, 1862-1895. Bowling Green, OH: Bowling Green State University Popular Press, 1982.

Adams, Sean Patrick. An Uneasy Truce: Worker Responses to Pullman's Model Town, 1880 -1894. Madison, WI: University of Wisconsin Press, 1992.

Adamson, Christopher R. „Punishment after Slavery: Southern State Penal Systems, 1865-1890." Social Problems 30, no. 5 (1983):555-69.

Agamben, Giorgio. Was ist ein Dispositiv? Berlin: Diaphenes, 2009.

Agger, Eugene E. „Our Large Change: The Denominations of the Currency.“ The Quarterly Journal of Economics 32, no. 2 (1918):257-77.

Aiken, Katherine G. Idaho's Bunker Hill: The Rise and Fall of a Great Mining Company, 1885-1981. Norman, OK: University of Oklahoma Press, 2005.

Alanen, Arnold R. Morgan Park Duluth, U.S. Steel, and the Forging of a Company Town. Minneapolis, MI: University of Minnesota Press, 2007.

Aldrich, Lisa J. Cyrus McCormick and the Mechanical Reaper. Greensboro, NC: Morgan Reynolds Pub, 2002.

Alexander, Benjamin F. Coxey's Army: Popular Protest in the Gilded Age. Baltimore, MD: Johns Hopkins University Press, 2015.

Alexander, Charles C. „Prophet of American Racism: Madison Grant and the Nordic Myth.“ Phylon. 1962, 23 (1):73-90.

Allen, Frederick Lewis. „The Great Pierpont Morgan: Pomp and Circumstance.“ In: Robert Manley und Seon Manley (Hg.). The Age of the Manager: A Treasury of Our Times. New York: Macmillan, 1962, S. 3-23.

Allen, James S. Reconstruction: The Battle for Democracy (1865-1876). New York: International Publishers, 1937.

Allen, Oliver E. The Tiger: The Rise and Fall of Tammany Hall. New York: Addison-Wesley, 1993. Allen, Will. The War on Bugs. White River Junction, VT: Chelsea Green Pub, 2008.

Alonso, Karen. Schenck v. United States: Restrictions on Free Speech. Springfield, NJ: Enslow Publishers, 1999.

Altman, Linda Jacobs. The Pullman Strike of 1894: Turning Point for American Labor. Brookfield, CT: Millbrook Press, 1994.

Alvarez, Alejandro. The Monroe Doctrine: Its Importance in the International Life of the States of the New World. Buffalo, NY: W.S. Hein, 2003

Alvarez, Alex. Native America and the Question of Genocide. Lanham, MD, Boulder, CO: Rowman \& Littlefield, 2016. 
Ambrose, Stephen E. Nothing Like It in the World: The Men Who Built the Transcontinental Railroad, 1863-1869. New York: Simon \& Schuster, 2000.

Anderson, Aaron D. Builders of a New South: Merchants, Capital, and the Remaking of Natchez, 1865-1914. Jackson, MS: University Press of Mississippi, 2013.

Anderson, Eric und Moss, Alfred A. . The Facts of Reconstruction: Essays in Honor of John Hope Franklin. Baton Rouge, LA: Louisiana State University Press, 1991.

Anderson, Gary Clayton. Sitting Bull and the Paradox of Lakota Nationhood. New York: Pearson/Longman, 2007.

Anderson, James D. The Education of Blacks in the South, 1860-1935. Chapel Hill, NC: University of North Carolina Press, 1988.

Anderson, Karen. Changing Woman: A History of Racial Ethnic Women in Modern America. New York: Oxford University Press, 1996.

Anderson, Nancy K, Linda S. Ferber und Helena Wright. Albert Bierstadt: Art \& Enterprise. New York: Hudson Hills Press, 1990.

Andersson, Rani-Henrik. The Lakota Ghost Dance of 1890. Lincoln, NE: University of Nebraska Press, 2008.

Angermann, Erich. „Der Imperialismus als Formwandel des amerikanischen Expansionismus: Eine Studie über den Gedanken einer zivilisatorischen Sendung der Vereinigten Staaten.“ Jahrbuch für Geschichte von Staat, Wirtschaft und Gesellschaft Lateinamerikas 4, no. 1 (1967):694-725.

Angermann, Erich. Die Vereinigten Staaten von Amerika seit 1917. München: Deutscher Taschenbuch-Verlag, 1978.

Angus, Ian. „Empire, Borders, Place: A Critique of Hardt and Negri’s Concept of Empire.“ [Web Page]: http://www.sfu.ca/personal/iangus/empire.pdf. Gesehen am 13.7.2015.

Angus, Ian. The World Outside: Collected Short Fiction about Women at Work. New York: Four Winds Press, 1977.

Antin, Mary. The Promised Land. Kila, MT: Kessinger Publishing, 2004.

Applegate, Edd. The Rise of Advertising in the United States: A History of Innovation to 1960. Lanham, MD: Scarecrow Press, 2012.

Apps, Jerold W. Horse-Drawn Days: A Century of Farming with Horses. Madison, WI: Wisconsin Historical Society Press, 2010.

Apt, Benjamin L. „Mahan’s Forebears: The Debate over Maritime Strategy, 1868-1883.“ Naval War College Review 50 (1997):86-111.

Araral, Eduardo. „Bureaucratic Incentives, Path Dependence, and Foreign Aid: An Empirical Institutional Analysis of Irrigation in the Philippines.“ Policy Sciences. 2005, 38 (2/3):131-157.

Arestis, Philip und Sawyer, Malcolm C. Path Dependency and Macroeconomics. New York: Palgrave Macmillan, 2009.

Armstrong, Kenneth A. und Bulmer, Simon. The Governance of the Single European Market. Manchester, New York: Manchester University Press, 1998.

Arnesen, Eric. Black Protest and the Great Migration: A Brief History with Documents. Boston, MA: Bedford/St. Martin's, 2003.

Arnesen, Eric. Encyclopedia of U.S. Labor and Working-Class History. New York: Routledge, 2007.

Arnesen, Eric. The Human Tradition in American Labor History. Wilmington, DE: SR Books, 2004. 
Arnesen, Eric. Waterfront Workers of New Orleans: Race, Class, and Politics, 1863-1923. Urbana, IL: University of Illinois Press, 1994.

Aron, Cindy Sondik. Ladies and Gentlemen of the Civil Service: Middle-Class Workers in Victorian America. New York: Oxford University Press, 1987.

Aron, Cindy Sondik. Working at Play: A History of Vacations in the United States. New York: Oxford University Press, 1999.

Aron, Raymond. The Imperial Republic: The United States and the World, 1945-1973. New Brunswick, NJ: Transaction Publishers, 2009.

Aron, Stephen. „Pioneers and Profiteers: Land Speculation and the Homestead Ethic in Frontier Kentucky.“ The Western Historical Quarterly 23, no. 2 (1992):179-98.

Aronson, Michael. Nickelodeon City: Pittsburgh at the Movies, 1905-1929. Pittsburgh, PA: University of Pittsburgh Press, 2008.

Arthur, W. Brian. Increasing Returns and Path Dependence in the Economy. Ann Arbor, MI: University of Michigan Press, 1994.

Arthur, W. Brian. „Competing Technologies, Increasing Returns, and Lock-In by Historical Events.“ The Economic Journal. 1989, 99 (394):116-131.

Ashby, Ruth. Boss Tweed and Tammany Hall. San Diego, CA: Blackbirch Press, 2002.

Atkins, Stephen E. Encyclopedia of Right-Wing Extremism in Modern American History. Santa Barbara, CA: ABC-CLIO, 2011.

Atkinson, Carol L. Military Soft Power: Public Diplomacy through Military Educational Exchanges. Plymouth: Rowland \& Littlefield, 2014.

Aubenas, René. La Vie Exemplaire de Carl Schurz 1829-1906, Champion de la Liberté dans L’Ancien et le Nouveau Monde, les Années de Lutte. Paris: La Pensée Universelle, 1972.

Auchincloss, Louis. J.P. Morgan the Financier As Collector. New York: H.N. Abrams, 1990. Avrich, Paul. The Haymarket Tragedy. Princeton, N): Princeton University Press, 1984.

Avrich, Paul. und Karen Avrich. Sasha and Emma: The Anarchist Odyssey of Alexander Berkman and Emma Goldman. Cambridge, MA: Belknap Press of Harvard University Press, 2012.

Ayers, Edward L. The Promise of the New South: Life after Reconstruction. Oxford, New York: Oxford University Press, 2007.

Bacevich, Andrew J. The Limits of Power: The End of American Exceptionalism. New York: Metropolitan Books, 2008.

Baecker, Thomas. Die deutsche Mexikopolitik 1913/1914. Berlin: Colloquium Verlag, 1971.

Baer, George W. One Hundred Years of Sea Power: The U.S. Navy, 1890-1990. Stanford, CA: Stanford University Press, 1994.

Baggett, James Alex. The Scalawags: Southern Dissenters in the Civil War and Reconstruction. Baton Rouge, LA: Louisiana State University Press, 2003.

Baier, Melanie. Die Pfadabhängigkeit: Zur Theorie der Pfadabhängigkeit, Pfadbrechung und Pfadkreation von Institutionen. 2004. [Web Page]: http://www.qucosa.de/fileadmin/data/ qucosa/documents/1462/1140595687176-1541.pdf. Gesehen am 5.5.2016.

Bailey, Anne M. und Llobera, Josep R. The Asiatic Mode of Production: Science and Politics. London, Boston, MA: Routledge \& Kegan Paul, 1981.

Bailey, Richard. Neither Carpetbaggers nor Scalawags: Black Officeholders during the Reconstruction of Alabama, 1867-1878. Montgomery, AL: NewSouth Books, 2010.

Bailey, Thomas A. „Why the United States Purchased Alaska.“ Pacific Historical Review 3 (1934):39-49. 
Bailey, Thomas A. and Kennedy, David M.. The American Spirit: United States History As Seen by Contemporaries. Lexington, MA: D.C. Heath, 1991.

Baily, Samuel L. Immigrants in the Lands of Promise: Italians in Buenos Aires and New York City, 1870-1914. Ithaca, NY: Cornell University Press, 1999.

Baily, Samuel L. und Eduardo José Míguez. Mass Migration to Modern Latin America. Wilmington, DE: Scholarly Resources, 2003.

Baker, Robert. Before Bioethics: A History of American Medical Ethics from the Colonial Period to the Bioethics Revolution. Oxford, New York: Oxford University Press, 2013.

Bakhtin, Mikhael M. „The Forms of Time and the Chronotope in the Novel: Notes toward a Historical Poetics.“ The Dialogic Imagination: Four Essays. Mikhael M. Bakhtin, 84-258. Austin, TX: University of Texas Press, 1981.

Balack, Ulf Frank. Die White-Collar-Gruppe in Philadelphia: Entwicklung, Struktur und Mobilität, 1900-1970. Hamburg: Universitätsverlag, 2001.

Balch, Thomas Willing. The Alabama Arbitration. Freeport, NY: Books for Libraries Press, 1969.

Baldwin, Davarian L. Chicago's New Negroes: Modernity, the Great Migration, \& Black Urban Life. Chapel Hill, NC: University of North Carolina Press, 2007.

Banaszak, Lee Ann. Why Movements Succeed or Fail: Opportunity, Culture, and the Struggle for Woman Suffrage. Princeton, NJ: Princeton University Press, 1996.

Banchoff, Thomas. „Path Dependence and Value-Driven Issues: The Comparative Politics of Stem Cell Research.“ World Politics. 2005, 57 (2):200-230.

Banner, Stuart. How the Indians Lost Their Land Law and Power on the Frontier. Cambridge, MA: Belknap Press of Harvard University Press, 2005.

Barber, Benjamin R. Fear's Empire: War, Terrorism, and Democracy. New York: W.W. Norton \& Co, 2003.

Bardaglio, Peter Winthrop. Reconstructing the Household: Families, Sex, and the Law in the Nineteenth-Century South. Chapel Hill, NC: University of North Carolina Press, 1995.

Barnes, Donna A. „Rebel Farmers: The Texas Farmers’ Alliance.“ In: David O’Donald Cullen und Kyle Grant Wilkison (Hg.). The Texas Left: The Radical Roots of Lone Star Liberalism. College Station, TX: Texas A\&M University Press, 2010, S. 36-52.

Barnes, William und Morgan, John Heath. The Foreign Service of the United States: Origins, Development, and Functions. Washington DC: Department of State, 1961.

Barnikel, Hans Heinrich. Probleme der wirtschaftlichen Konzentration. Darmstadt: Wissenschaftliche Buchgesellschaft, 1975.

Barrett, James R. William Z. Foster and the Tragedy of American Radicalism. Urbana, IL: University of Illinois Press, 1999.

Barreyre, Nicolas. „The Politics of Economic Crises: The Panic of 1873, the End of Reconstruction, and the Realignment of American Politics." The Journal of the Gilded Age and Progressive Era 10, no. 4 (2011):403-23.

Barrick, Michael Mathers. The Dangerous Delusion of American Exceptionalism. Granite Falls, NC: Defiantly Rural Pub, 2011.

Barron, Hal S. Those Who Stayed Behind: Rural Society in Nineteenth-Century New England. Cambridge, New York: Cambridge University Press, 1984.

Barry, Francis S. The Scandal of Reform: The Grand Failures of New York's Political Crusaders and the Death of Nonpartisanship. New Brunswick, N): Rutgers University Press, 2009.

Barsh, Russel Lawrence. „An American Heart of Darkness: The 1913 Expedition for American Citizenship.“ Great Plains Quarterly. 1993, 13 (2):115-91. 
Barth, Gunther Paul. Bitter Strength: A History of the Chinese in the United States, 1850-1870. Cambridge, MA: Harvard University Press, 1964.

Barth, Gunther Paul. Instant Cities: Urbanization and the Rise of San Francisco and Denver. Albuquerque, NM: University of New Mexico Press, 1988.

Barthes, Roland. „Le Discours de l'Histoire.“ Social Science Information 6, no. 4 (1967):63-75. Barthes, Roland. „L’Effet de Réel.“ Communications 11, no. 11 (1968):84-89.

Basch, Linda G., Blanc-Szanton, Cristina und Schiller, Nina Glick. Towards a Transnational Perspective on Migration: Race, Class, Ethnicity and Nationalism Reconsidered. New York: New York Academy of Sciences, 1992.

Basel, Roberta. Sequoyah: Iventor of Written Cherokee. Minneapolis, MN: Compass Point Books, 2007.

Beale, Howard K. Theodore Roosevelt and the Rise of America to World Power. Baltimore, MD: Johns Hopkins University Press, 1984.

Bean, Christopher B. A Stranger amongst Strangers: An Analysis of the Freedmen's Bureau Subassistant Commissioners in Texas, 1865-1868. Denton, TX: University of North Texas, 2008.

Beatty, Jack. Age of Betrayal: The Triumph of Money in America, 1865-1900. New York: Alfred A. Knopf, 2007.

Beatty, Jack. Colossus: How the Corporation Changed America. New York: Broadway Books, 2001.

Beauchamp, K. G. History of Telegraphy. London: Institution of Electrical Engineers, 2001.

Beauregard, Robert A. When America Became Suburban. Minneapolis, MN: University of Minnesota Press, 2006.

Becher, Ronald. Massacre along the Medicine Road: A Social History of the Indian War of 1864 in Nebraska Territory. Caldwell, ID: Caxton Press, 1999.

Beck, Tom. George M. Bretz: Photographer in the Mines. Catonsville, MD: University of Maryland Baltimore County Library, 1977.

Beck, Ulrich. „Jenseits von Klasse und Nation: Individualisierung und Transnationalisierung sozialer Ungleichheiten.“ Soziale Welt. 2008, 59 (4):301-325.

Beales, D. E. D. und Blanning, T. C. W. „Prince Kaunitz and ,The Primacy of Domestic Policy““. The International History Review. 1980, 2 (4):619-624.

Beckel, Deborah. Radical Reform: Interracial Politics in Post-Emancipation North Carolina. Charlottesville, VA: University of Virginia Press, 2011.

Becker, Manfred und Anja Beck. Die Quadriga postmoderner Beliebigkeit und ihre Folgen für Wirtschaft und Gesellschaft. Eine empirische Studie zur Entwicklung und Steuerung von Individualisierung, Fragmentierung, Temporalisierung und Ästhetisierung. München und Mehring: Rainer Hampp Verlag, 2014.

Becker, Peter Emil. Sozialdarwinismus, Rassismus, Antisemitismus und völkischer Gedanke. Stuttgart, New York: G. Thieme, 1990.

Becker, William H. „1899-1920: America Adjusts to World Power.“ In: William H. Becker und Samuel F. Wells (Hg.). Economics and World Power: An Assessment of American Diplomacy since 1789. New York: Columbia University Press, 1984, S. 173-223.

Becker, William H. „American Manufacturers and Foreign Markets, 1870-1900: Business Historians and the ,New Economic Determinists ““. The Business History Review. 1973, 47 (4):466- 481. 
Bederman, Gail. Manliness \& Civilization: A Cultural History of Gender and Race in the United States, 1880-1917. Chicago, IL: University of Chicago Press, 1995.

Beeby, James M. Revolt of the Tar Heels: The North Carolina Populist Movement, 1890-1901. Jackson, MS: University Press of Mississippi, 2008.

Beede, Benjamin R. The War of 1898 and U.S. Interventions, 1898-1934: An Encyclopedia. New York: Garland, 1994.

Beerbühl, Margrit Schulte. „War England ein Sonderfall der Industrialisierung? Der ökonomische Einfluss der protestantischen Immigranten auf die Entwicklung der englischen Wirtschaft vor der Industrialisierung." Geschichte und Gesellschaft 21, no. 4 (1995):479-505.

Beisel, Nicola Kay. Imperiled Innocents: Anthony Comstock and Family Reproduction in Victorian America. Princeton, NJ: Princeton University Press, 1997.

Beisner, Robert L. (Hg.). American Foreign Relations since 1600: A Guide to the Literature. Santa Barbara, CA: ABC-CLIO, 2003.

Beisner, Robert L. Twelve against Empire - the Anti-Imperialists, 1898-1900. Chicago, IL: Imprint Publications, 1992.

Belanger, Dian Olson. Enabling American Innovation: Engineering and the National Science Foundation. West Lafayette, IN: Purdue University Press, 1998.

Belko, William S. „John C. Calhoun and the Creation of the Bureau of Indian Affairs: An Essay on Political Rivalry, Ideology, and Policymaking in the Early Republic.“ The South Carolina Historical Magazine. 2004 Jul 1, 105(3):170-197

Bellesiles, Michael A. 1877: America's Year of Living Violently. New York: New Press. Distributed by Perseus Distribution, 2010.

Belz, Herman. „Abraham Lincoln and American Constitutionalism.“ The Review of Politics 50, no. 2 (1988):169-97.

Belz, Herman. Emancipation and Equal Rights Politics and Constitutionalism in the Civil War Era. New York: Norton, 1978.

Belz, Herman. Reconstructing the Union: Theory and Policy during the Civil War. Westport, CT: Greenwood Press, 1979.

Bemis, Samuel Flagg. The Latin American Policy of the United States. New York: Harcourt, Brace and company, 1943.

Bemong, Nele, Borghart, Pieter, De Dobbeleer, Michel und Demoen, Kristoffel. Bakhtin's Theory of the Literary Chronotope: Reflections, Applications, Perspectives. Gent: Ginko, Academia Press, 2010.

Bender, Peter. Weltmacht Amerika: Das Neue Rom. Stuttgart: Klett-Cotta, 2003.

Bender, Thomas. Rethinking American History in a Global Age. Berkeley, CA: University of California Press, 2002.

Bendroth, Margaret Lamberts und Lieson Brereton, Virginia. Women and Twentieth-Century Protestantism. Urbana, IL: University of Illinois Press, 2002.

Benedict, Michael Les. „Laissez-Faire and Liberty: A Re-Evaluation of the Meaning and Origins of Laissez-Faire Constitutionalism.“ Law and History Review 3, no. 2 (1985):293-331.

Benedict, Michael Les. „Southern Democrats in the Crisis of 1876-1877: A Reconsideration of Reunion and Reaction." The Journal of Southern History 46, no. 4 (1980):489-524.

Benjamin, Jules R. The United States and the Origins of the Cuban Revolution. An Empire of Liberty in an Age of National Liberation. Princeton, NJ: Princeton University Press, 1990. 
Bennett, Andrew und Elman, Colin. „Complex Causal Relations and Case Study Methods: The Example of Path Dependence." Political Analysis. 2006, 14(3):250-267.

Bennett, Bridget. The Damnation of Harold Frederic: His Lives and Works. Syracuse, NY: Syracuse University Press, 1997.

Bennett, William John. America: The Last Best Hope. Nashville, TN: Nelson Current, 2007.

Bensel, Richard Franklin. Yankee Leviathan: The Origins of Central State Authority in America, 1859-1877. Cambridge, New York: Cambridge University Press, 1990.

Benson, Nicholas A. A Clumsy War: An Inquiry on the Operational Ambiguities of America's Counterinsurgency Campaign in the Philippines and Its Opaque History [Web Page]: http://www.usna.edu/History/honors/2003/BensonThesis.doc. Gesehen am 15. November 2003.

Benson, Susan Porter. Counter Cultures: Saleswomen, Managers, and Customers in American Department Stores, 1890-1940. Urbana, IL: University of Illinois Press, 1986.

Bentley, George R. A History of the Freedmen's Bureau. New York: Octagon Books, 1970.

Bentley, George R. „The Political Activity of the Freedmen's Bureau in Florida.“ The Florida Historical Quarterly 28, no. 1 (1949):28-37.

Bergmann, Peter. „American Exceptionalism and German ,Sonderweg in Tandem.“ The International History Review 23, no. 3 (2001):505-34.

Berkley, George E. The Filenes. Boston, MA: International Pocket Library, 1998.

Berlin, Ira. Free at Last: A Documentary History of Slavery, Freedom, and the Civil War. New York: The New Press, 1992.

Berlin, Ira. Freedom: A Documentray History of Emancipation, 1861-1867. The Wartime Genesis of Free Labor: The Upper South. Cambridge, New York: Cambridge University Press, 1993.

Berlin, Ira. Slaves No More: Three Essays on Emancipation and the Civil War. Cambridge, New York: Cambridge University Press, 1992.

Berlin, Ira, Glymph, Thavolia, Miller, Steven F., Reidy, Joseph P., Rowland, Leslie S. und Saville, Julie (Hg.). Freedom: A Documentary History of Emancipation, 1861-1867. Series I, Volume III: The Wartime Genesis of Free Labor: The Lower South. Cambridge, New York: Cambridge University Press, 1990.

Berlin, Ira, Joseph P. Reidy und Leslie S. Rowland. The Black Military Experience. Cambridge, New York: Cambridge University Press, 1982.

Berman, David R. Radicalism in the Mountain West, 1890-1920: Socialists, Populists, Miners, and Wobblies. Boulder, CO: University Press of Colorado, 2007.

Berman, John S. Coney Island. New York: Barnes and Noble Books, 2003.

Bernstein, David. „The Supreme Court and ,Civil Rights', 1886-1908.“ The Yale Law Journal 100, no. 3 (1990):725- 44.

Bernstein, Peter L. The Power of Gold: The History of an Obsession. New York: Wiley, 2004.

Bernstein, Peter L. Wedding of the Waters: The Erie Canal and the Making of a Great Nation. New York: W.W. Norton, 2005.

Berressem, Hanjo. „Oekologik|Oekosophie: Das Ereignis der Stadt.“ In: Norbert Finzsch (Hg.). Clios Natur: Vergleichende Aspekte der Umweltgeschichte. Berlin, Münster, Hamburg, New York: LIT, 2008, S. 8-41.

Beschloss, Michael R. Presidential Courage: Brave Leaders and How They Changed America, 1789-1989. New York: Simon \& Schuster, 2007. 
Bethel, Elizabeth. „The Freedmen's Bureau in Alabama.“ The Journal of Southern History 14, no. 1 (1948):49-92.

Better, Shirley Jean. Institutional Racism: A Primer on Theory and Strategies for Social Change. Lanham, MD: Rowman \& Littlefield Publishers, 2008.

Beyer, Jürgen. „Pfadabhängigkeit ist nicht gleich Pfadabhängigkeit! Wider den impliziten Konservatismus eines gängigen Konzepts.“ Zeitschrift für Soziologie. 2005, 34(1):5-21.

Beyer, Jürgen. „The Same or Not the Same: On the Variety of Mechanisms of Path Dependence.“ International Journal of Social Sciences. 2010, 5(1):1-11.

Bianculli, Anthony J. Trains and Technology: The American Railroad in the Nineteenth Century. Newark, DE: University of Delaware Press, 2001-2003.

Binda, Lawrance. The Big, Bad Book of Mike: Rogues, Rascals and Rapscallions Names Micheal, Mike and Mickey. Lincoln, NE: iUniverse, 2003.

Birmingham, Stephen. Our Crowd: The Great Jewish Families of New York. Syracuse, NY: Syracuse University Press, 1996.

Bishop, Judson W. „History of the St. Paul \& Sioux City Railroad, 1864-1881.“ Minnesota Historical Collections 10 (1903):399-415.

Bissett, Jim. Agrarian Socialism in America: Marx, Jefferson, and Jesus in the Oklahoma Countryside, 1904 -1920. Norman, OK: University of Oklahoma Press, 1999.

Blackburn, George M. „Paris Newspapers and the American Civil War.“ Illinois Historical Journal. 1991, 84(3):177-19

Blackmon, Douglas A. Slavery by Another Name: The Re-Enslavement of Black People in America from the Civil War to World War II. New York: Doubleday, 2008.

Blakemore, Harold. British Nitrates and Chilean Politics, 1886-1896: Balmaceda and North. London: Athlone Press for the Institute of Latin American Studies, 1974.

Blassingame, John W. The Slave Community Plantation Life in the Antebellum South. New York: Oxford University Press, 1979.

Blaszczyk, Regina Lee. American Consumer Society, 1865-2005 from Hearth to HDTV. Wheeling, IL: Harlan Davidson, Inc, 2009.

Blatter, Joachim, Janning, Frank und Wagemann, Claus. Qualitative Politikanalyse: Eine Einführung in Forschungsansätze und Methoden. Wiesbaden: VS Verlag für Sozialwissenschaften, 2007.

Bleakley, Hoyt und Lin, Jeffrey Y. Portage: Path Dependence and Increasing Returns in U.S. History. Cambridge, MA: National Bureau of Economic Research, 2010.

Blewett, Mary H. The Last Generation Work and Life in the Textile Mills of Lowell, Massachusetts, 1910-1960. Amherst: University of Massachusetts Press, 1990.

Blewett, Mary H. Men, Women, and Work Class, Gender, and Protest in the New England Shoe Industry, 1780-1910. Urbana, IL: University of Illinois Press, 1988.

Blom, Ida. Medicine, Morality, and Political Culture: Legislation on Venereal Disease in Five Northern European Countries, c.1870-c.1995. Lund: Nordic Academic Press, 2012.

Blue, Frederick J. Charles Sumner and the Conscience of the North. Arlington Heights, IL: Harlan Davidson, 1994.

Blum, Edward J. Reforging the White Republic: Race, Religion, and American Nationalism, 1865-1898. Baton Rouge, LA: Louisiana State University Press, 2005.

Boehm, Lisa Krissoff. Popular Culture and the Enduring Myth of Chicago, 1871-1968. New York: Routledge, 2004. 
Bolkhovitinov, Nikolai N. „How It Was Decided to Sell Alaska.“ International Affairs (1988):116-26.

Boller, Paul F. Presidential Campaigns from George Washington to George W. Bush. New York: Oxford University Press, 2004.

Bontje, Marco Arjan, Musterd, Sako und Pelzer, Peter. Inventive City-Regions: Path Dependence and Creative Knowledge Strategies. Farnham, Burlington, VT: Ashgate, 2011.

Boot, Max. „Neocons.“ Foreign Policy. 2004, (140):20 - 28.

Borchard, Gregory A. Abraham Lincoln and Horace Greeley. Carbondale, IL: Southern Illinois University Press, 2011.

Borchart, Joachim. Der Europäische Eisenbahnkönig Bethel Henry Strousberg. München: C.H. Beck, 1991.

Borchert, James und Borchert, Susan. „Downtown, Uptown, Out of Town: Diverging Patterns of Upper-Class Residential Landscapes in Buffalo, Pittsburgh, and Cleveland, 1885-1935.“ Social Science History 26, no. 2 (2002):311- 46.

Borgens, Edward G. Background of the Monroe Doctrine. New York: Vantage Press, 2004. Borjas, George J. und National Bureau of Economic Research. Mexican Immigration to the United States. Chicago, IL: University of Chicago Press, 2007.

Borón, Atilio. Empire and Imperialism: A Critical Reading of Michael Hardt and Antonio Negri. London, New York, New York: Zed Books. Distributed in the USA exclusively by Palgrave Macmillan, 2005.

Bose, Purnima. „General Electric, Corporate Personhood, and the Emergence of the Professional Manager.“ In: Purnima Bose und Laura E. Lyons (Hg.). Cultural Critique and the Global Corporation. Bloomington, IN: Indiana University Press, 2010, S. 28-63.

Boutier, Jean. „Fernand Braudel als Historiker des Ereignisses.“ In: Andreas Suter und Manfred Hettling (Hg.). Struktur und Ereignis. Göttingen: Vandenhoeck \& Ruprecht, 2001, S. $138-57$.

Bowen, David Warren. Andrew Johnson and the Negro. Knoxville.TN: University of Tennessee Press, 1989.

Bowes, John P. The Trail of Tears: Removal in the South. New York: Chelsea House, 2007.

Bowler, Peter J. Darwin Deleted: Imagining a World Without Darwin. Chicago, IL: University of Chicago Press, 2013.

Bowman, Scott R. The Modern Corporation and American Political Thought Law, Power, and Ideology. University Park, PA: Pennsylvania State University Press, 1996.

Bracher, Karl Dietrich. Deutscher Sonderweg: Mythos Oder Realität? München: R. Oldenbourg, 1982.

Bradford, James C. Admirals of the New Steel Navy: Makers of the American Naval Tradition, 1880-1930. Annapolis, MD: Naval Institute Press, 1990.

Bradley, Mark L. The Army and Reconstruction, 1865-1877. Washington, DC: Center of Military History, 2015.

Brands, Henry William. American Colossus: The Triumph of Capitalism, 1865-1900. New York: Doubleday, 2010.

Brands, Henry William. The Money Men: Capitalism, Democracy, and the Hundred Years' War over the American Dollar. New York: W.W. Norton \& Co, 2006.

Brands, Henry William. The Reckless Decade: America in the 1890s. Chicago, IL: University of Chicago Press, 2002.

Braudel, Fernand. Les Écrits de Fernand Braudel. Paris: Éditions de Fallois, 1997-2001. 
Braun, Felipe Kuhn. História da Imigraçao Alema no Sul do Brasil. Porte Alegre: Costoli Soluções Gráficas, 2010.

Bravo Valdivieso, Germán. El Incidente del „USS Baltimore“ Como una Gresca de Marineros Borrachos, en Valparaíso, Estuvo a Punto de Provocar una Guerra entre Chile y Estados Unidos. Valparaiso: Ediciones Altazor, 2002.

Brebner, J. Bartlet. „A Changing North Atlantic Triangle.“ International Journal. 1948, 3(4):309-319.

Brecher, Jeremy. Strike! Oakland, CA: PM Press, 2014.

Brenner, Aaron, Day, Benjamin und Ness, Immanuel. The Encyclopedia of Strikes in American History. Armonk, NY: M. E. Sharpe, 2009.

Bresnahan, Roger J. In Time of Hesitation: American Anti-Imperialists and the Philippine-American War. Quezon City, Philippines: New Day Publishers, 1981.

Brewer, Stewart. Borders and Bridges: A History of U.S.-Latin American Relations. Westport, CT: Praeger Security International, 2006.

Brezina, Corona. America's Political Scandals in the Late 1800s: Boss Tweed and Tammany Hall. New York: Rosen Pub. Co, 2004.

Brice, William R. Myth, Legend, Reality: Edwin Laurentine Drake and the Early Oil Industry. Oil City, PA: Oil Region Alliance of Business, Industry \& Tourism, 2009.

Bridger, Bobby. Buffalo Bill and Sitting Bull Inventing the Wild West. Austin, TX: University of Texas Press, 2002.

Bridges, Amy. Morning Glories: Municipal Reform in the Southwest. Princeton, NJ: Princeton University Press, 1997.

Bristow, Nancy K. American Pandemic: The Lost Worlds of the 1918 Influenza Epidemic. Oxford, New York: Oxford University Press, 2012.

Broadwater, Robert P. Ulysses S. Grant: A Biography. Santa Barbara, CA: Greenwood, 2012.

Brock, James W. und Kenneth G Elzinga. Antitrust, the Market, and the State the Contributions of Walter Adams. Armonk, NY: M. E. Sharpe, 1991.

Brock, Ralph H. „,The Republic of Texas Is No More‘: An Answer to the Claim That Texas Was Unconstitutionally Annexed to the United States.“ Texas Tech Law Review 28 (1997):680-745.

Broder, Sherri. „Ideologies of Domesticity: 1890-1929.“ Diss. Hampshire College, 1979.

Brodie, Fawn McKay. Thaddeus Stevens, Scourge of the South. New York: Norton, 1959.

Brody, David. Labor in Crisis the Steel Strike of 1919. Urbana, IL: University of Illinois Press, 1987.

Brook, Timothy (Hg.). The Asiatic Mode of Production in China. Armonk, NY: M. E. Sharpe, 1989.

Brookes, Jean Ingram. International Rivalry in the Pacific Islands, 1800-1875. New York: Russell \& Russell, 1972.

Brooks, Stephen. American Exceptionalism in the Age of Obama. New York: Routledge, 2013. Brophy, James M. Capitalism, Politics, and Railroads in Prussia, 1830-1870. Columbus, $\mathrm{OH}$ : Ohio State University Press, 1998.

Brown, Benjamin Clifford. Racial Conflict and Violence in the Labor Market Roots in the 1919 Steel Strike. New York: Garland Pub, 1998.

Brown, Canter. Florida's Black Public Officials, 1867-1924. Tuscaloosa, AL: University of Alabama Press, 1998. 
Brown, Jonathan C. und Knight, Alan. The Mexican Petroleum Industry in the Twentieth

Century. Austin, TX: University of Texas Press, 1992.

Brown, Mark Herbert. The Flight of the Nez Perce. New York: Putnam, 1967.

Brown, Victoria Bissell. The Education of Jane Addams. Philadelphia, PA: University of Pennsylvania Press, 2007.

Browning, James B. „The North Carolina Black Code.“ The Journal of Negro History 15, no. 4 (1930):461-73.

Bruce, Robert V. 1877, Year of Violence. Chicago, IL: I.R. Dee, 1989.

Bruner, Robert F. und Sean D. Carr. The Panic of 1907: Lessons Learned from the Market's

Perfect Storm. Hoboken, N): John Wiley \& Sons, 2007.

Brunner, Otto, Werner Conze und Koselleck, Reinhart. Geschichtliche Grundbegriffe:

Historisches Lexikon zur politisch-sozialen Sprache in Deutschland. Stuttgart: E. Klett, $1972-1997$.

Brunnbauer, Ulf. Transnational Societies, Transterritorial Politics: Migrations in the (Post-)

Yugoslav Region, 19th-21st Century. München: R. Oldenbourg, 2009.

Bryan, Ferald Joseph. Henry Grady or Tom Watson? The Rhetorical Struggle for the New South, 1880-1890. Macon, GA: Mercer University Press, 1994.

Bryan, Mary Lynn McCree und Freeman Davis, Allen. 100 Years at Hull-House. Bloomington: Indiana University Press, 1990.

Bryson, Phillip J. The Economics of Henry George: History's Rehabilitation of America's Greatest Early Economist. New York: Palgrave Macmillan, 2011.

Bublitz, Hannelore, Hanke, Christine und Seier, Andrea. Der Gesellschaftskörper: Zur Neuordnung von Kultur und Geschlecht um 1900. Frankfurt am Main, New York: Campus, 2000.

Buder, Stanley. Capitalizing on Change: A Social History of American Business. Chapel Hill, NC: University of North Carolina Press, 2009.

Buder, Stanley. Pullman: An Experiment in Industrial Order and Community Planning, 1880 -1930. New York: Oxford University Press, 1967.

Budiansky, Stephen. The Bloody Shirt: Terror after Appomattox. New York: Viking, 2008.

Bueno de Mesquita, Bruce. Domestic Politics and International Relations. International Studies Quarterly. 2002, 46(1):1-9.

Buhle, Paul und Buhle, Mari Jo (Hg.). History of Woman Suffrage: The Concise History of Woman Suffrage. Selections from History of Woman Suffrage, Edited by Elizabeth Cady Stanton, Susan B. Anthony, Matilda Joslyn Gage und the National American Woman Suffrage Association. Urbana, IL: University of Illinois Press, 2005.

Buhle, Paul M. und Rice-Maximin, Edward. William Appleman Williams: The Tragedy of Empire. New York: Routledge, 1995.

Bullough, William A. The Blind Boss \& His City: Christopher Augustine Buckley and Nineteenth-Century San Francisco. Berkeley, CA: University of California Press, 1979.

Burbank, David T. Reign of the Rabble: The St. Louis General Strike of 1877. New York: A. M. Kelley, 1966.

Burchard, Veronica. „Lincoln's Refutation of Secession.“ OAH Magazine of History 21, no. 1 (2007):29-32.

Burgan, Michael. Breaker Boys: How a Photograph Helped End Child Labor. Mankato, MN: Compass Point Books, 2012. 
Burgan, Michael. The Haymarket Square Tragedy. Minneapolis, MN: Compass Point Books, 2006.

Burgan, Michael. The Pullman Strike of 1894. Minneapolis, MN: Compass Point Books, 2008.

Burgers, Johannes Hendrikus. „Max Nordau, Madison Grant, and Racialized Theories of Ideology.“ Journal of the History of Ideas. 2011, 72(1):119-140.

Burgoyne, Arthur Gordon. The Homestead Strike of 1892. Pittsburgh: University of Pittsburgh Press, 1979.

Burke, Martin J. The Conundrum of Class: Public Discourse on the Social Order in America. Chicago, IL: University of Chicago Press, 1995.

Burlin, Paul T. Imperial Maine and Hawai'i: Interpretive Essays in the History of Nineteenth-Century American Expansion. Lanham, MD: Lexington Books, 2006.

Burlingame, Michael. Abraham Lincoln a Life. Baltimore: Johns Hopkins University Press, 2008.

Burns, James MacGregor und Dunn, Susan. The Three Roosevelts: Patrician Leaders Who Transformed America. New York: Atlantic Monthly Press, 2001.

Burns, Richard Dean, Siracusa, Joseph M. und Flanagan, Jason C.. American Foreign Relations since Independence. Santa Barbara, CA: ABC-Clio, 2013.

Burr, Lawrence und Bryan, Tony. US Cruisers 1883-1908: The Birth of the Steel Navy. Oxford: Osprey, 2008.

Burrows, Edwin G. und Wallace, Mike. Gotham: A History of New York City to 1898. New York: Oxford University Press, 1999.

Burton, David Henry. Cecil Spring Rice: A Diplomat's Life. Rutherford, London, Cranbury, NJ: Fairleigh Dickinson University Press. Associated University Presses, 1990.

Buschena, David und Zilberman, David. „Generalized Expected Utility, Heteroscedastic Error, and Path Dependence in Risky Choice." Journal of Risk and Uncertainty 2000, 20(1):67-88,

Butler, Leslie. Critical Americans: Victorian Intellectuals and Transatlantic Liberal Reform. Chapel Hill, NC: University of North Carolina Press, 2007.

Byington, Margaret Frances. Homestead, the Households of a Mill Town. New York: Arno, 1969.

Byrne, William A. „,Uncle Billy' Sherman Comes to Town: The Free Winter of Black Savannah.“ The Georgia Historical Quarterly 79, no. 1 (1995):91-116.

C. Barron McIntosh. „One Man's Sequential Land Alienation on the Great Plains.“ Geographical Review 71, no. 4 (1981):427- 45.

Cachan, Manuel. „Justice Stephen Field and ,Free Soil, Free Labor Constitutionalism“: Reconsidering Revisionism." Law and History Review 20, no. 3 (2002):541-76.

Cahan, Richard. A Court That Shaped America: Chicago's Federal District Court from Abe Lincoln to Abbie Hoffman. Evanston, IL: Northwestern University Press, 2002.

Calavita, Kitty. „The Paradoxes of Race, Class, Identity, and ,Passing: Enforcing the Chinese Exclusion Acts, 1882-1910.“ Law \& Social Inquiry 25, no. 1 (2000):1- 40.

Calhoun, Charles W. From Bloody Shirt to Full Dinner Pail: The Transformation of Politics and Governance in the Gilded Age. New York: Hill and Wang, 2010.

Calhoun, Charles W. Minority Victory Gilded Age Politics and the Front Porch Campaign of 1888. Lawrence, Kan: University Press of Kansas, 2008.

California, Legislature und Senate. California's Compulsory Sterilization Policies, 1909-1979: July 16, 2003 Informational Hearing. Sacramento, CA: Senate Publications, 2003.

Callinicos, Alex. Imperialism and Global Political Economy. Cambridge, Malden, MA: Polity Press, 2009. 
Callinicos, Alex. The New Mandarins of American Power: The Bush Administration's Plans for the World. Cambridge, Malden, MA: Polity Press, 2003.

Campbell, Ballard C. Disasters, Accidents, and Crises in American History: A Reference Guide to the Nation's Most Catastrophic Events. New York: Facts on File, 2008.

Campbell, Ballard C. The Human Tradition in the Gilded Age and Progressive Era. Wilmington, DE: SR Books, 2000.

Campbell, Duncan Andrew. English Public Opinion and the American Civil War. Woodbridge, Suffolk, Rochester, NY: Royal Historical Society/Boydell Press, 2003.

Campbell, James E. The Presidential Pulse of Congressional Elections. Lexington, KY: University Press of Kentucky, 1997.

Cannato, Vincent J. American Passage: The History of Ellis Island. New York: Harper, 2009.

Capoccia, Giovanni und Kelemen, R. Daniel. „The Study of Critical Junctures: Theory, Narrative, and Counterfactuals in Historical Institutionalism.“ World Politics 2007, 59(3):341-369,

Capps, John M. und Capps, Donald (Hg.). James and Dewey on Belief and Experience. Urbana, IL: University of Illinois Press, 2005.

Carbaugh, Robert J. International Economics. Mason, $\mathrm{OH}$ : South-Western Cengage Learning, 2011.

Cardyn, Lisa. „Sexualized Racism/Gendered Violence: Outraging the Body Politic in the Reconstruction South.“ Michigan Law Review 100, no. 4 (2002):675-867.

Carlson, Leonard A. Indians, Bureaucrats, and Land: The Dawes Act and the Decline of Indian Farming. Westport, CT: Greenwood Press, 1981.

Carosso, Vincent P und Carosso, Rose C.. The Morgans: Private International Bankers, 1854-1913. Cambridge, MA: Harvard University Press, 1987.

Carrigan, William D und Webb, Clive. Forgotten Dead: Mob Violence against Mexicans in the United States, 1848-1928. Oxford, New York: Oxford University Press, 2013.

Carroll, Archie B., Lipartito, Kenneth, Post, James E., Hogue Werhane, Patricia und Goodpaster, Kenneth E.. Corporate Responsibility: The American Experience. Cambridge, New York: Cambridge University Press, 2012.

Carter, Dan T. When the War Was Over: The Failure of Self-Reconstruction in the South, 1865-1867. Baton Rouge, LA: Louisiana State University Press, 1985.

Carter, Julian. The Heart of Whiteness: Normal Sexuality and Race in America, 1880-1940. Durham: Duke University Press, 2007.

Carter, Robert A. Buffalo Bill Cody: The Man behind the Legend. New York: Wiley, 2000.

Carter, Susan and Sutch, Richard. „Fixing the Facts: Editing of the 1880 U.S. Census of Occupations with Implications for Long-Term Labor Force Trends and the Sociology of Official Statistics." Historical Methods. 1996 (29):5-24.

Cartosio, Bruno und Debouzy, Marianne. In the Shadow of the Statue of Liberty: Immigrants, Workers and Citizens in the American Republic, 1880-1920. Saint-Denis: Presses Universitaires de Vincennes, 1988.

Carwardine, Richard. Lincoln: A Life of Purpose and Power. New York: Alfred A. Knopf, 2006.

Casanovas, Joan. Bread or Bullets! Urban Labor and Spanish Colonialism in Cuba, 1850-1898. Pittsburgh, PA: University of Pittsburgh Press, 1998.

Case, Theresa Ann. The Great Southwest Railroad Strike and Free Labor. College Station, TX: Texas A\&M University Press, 2010.

Cashman, Sean Dennis. America Ascendant from Theodore Roosevelt to FDR in the Century of American Power, 1901-1945. New York: New York University Press, 1998. 
Cashman, Sean Dennis. America in the Age of the Titans: The Progressive Era and World War I. New York: New York University Press, 1988.

Cashman, Sean Dennis. America in the Gilded Age: From the Death of Lincoln to the Rise of Theodore Roosevelt. New York: New York University Press, 1993.

Catano, James V. Ragged Dicks: Masculinity, Steel, and the Rhetoric of the Self-Made Man. Carbondale, IL: Southern Illinois University Press, 2001.

Cates, David und Armstrong, Margalynne. Plessy V. Ferguson: Segregation and the Separate but Equal Policy. Minneapolis, MN: ABDO Pub, 2013.

Catlin, Daniel. Good Work Well Done: The Sugar Business Career of Horace Havemeyer, 1903-1956. New York: D. Catlin, 1988.

Cefrey, Holly. The Sherman Antitrust Act: Getting Big Business under Control. New York: Rosen Pub. Group, 2004.

Ceplair, Larry. Anti-Communism in Twentieth-Century America: A Critical History. Santa Barbara, CA: Praeger, 2011.

Chamberlain, John. Farewell to Reform the Rise, Life and Decay of the Progressive Mind in America. Chicago, IL: Quadrangle Books, 1965.

Chandler, Alfred D. The Railroads: Pioneers in Modern Management. New York: Arno Press, 1979.

Chandler, Alfred D. The Visible Hand: The Managerial Revolution in American Business. Cambridge, MA: Belknap Press, 1977.

Chandler, Alfred D. und Hikino, Takashi. Scale and Scope: The Dynamics of Industrial Capitalism. Cambridge, MA: Belknap Press, 1994.

Chapman, Richard A. The Civil Service Commission, 1855-1991: A Bureau Biography. London, New York: Routledge, 2004.

Chapuis, Robert J. und Joel, Amos E.. 100 Years of Telephone Switching (1878-1978). Amsterdam, Washington, DC: IOS Press. Ohmsha, 2003.

Chardavoyne, David G. United States District Court for the Eastern District of Michigan: People, Law, and Politics. Detroit, MI: Wayne State University Press, 2012.

Cherepanova, Rozaliya. „Discourse on a Russian ,Sonderweg: European Models in Russian Disguise." Studies in East European Thought 62, no. $3 / 4$ (2010):315-29.

Chernow, Ron. The House of Morgan: An American Banking Dynasty and the Rise of Modern Finance. New York: Grove Press, 2001.

Chernow, Ron. Titan: The Life of John D. Rockefeller, Sr. New York: Random House, 1998.

Chevalier, Louis. Laboring Classes and Dangerous Classes in Paris during the First Half of the Nineteenth Century. New York: Howard Fertig, 2000.

Chhetri, Netra B., Easterling, William E., Terando, Adam und Mearns, Linda. „Modeling Path Dependence in Agricultural Adaptation to Climate Variability and Change." Annals of the Association of American Geographers 2010, 100(4):894-907.

Childs, William R. „State Regulators and Pragmatic Federalism in the United States, 1889-1945.“ The Business History Review 75, no. 4 (2001):701-38.

Chisholm, Donald. Waiting for Dead Men's Shoes Origins and Development of the U.S. Navy's Officer Personnel System, 1793-1941. Stanford, CA: Stanford University Press, 2001.

Chung, Hwan-Woo. „Economic Reform and Path Dependence in China: A Comparative Study of Reform and Development in Nanjing and Suzhou.“ Asian Perspective 2003, 27(2):205-239. 
Chung, Hye Seung. Hollywood Asian: Philip Ahn and the Politics of Cross-Ethnic Performance. Philadelphia: Temple University Press, 2006.

Churella, Albert J. The Pennsylvania Railroad: Building an Empire, 1846-1917. Philadelphia, PA: University of Pennsylvania Press, 2013-.

Cimbala, Paul A. The Freedmen's Bureau: Reconstructing the American South after the Civil War. Malabar, FL: Krieger Pub, 2005.

Cimbala, Paul A. „The Freedmen's Bureau, the Freedmen, and Sherman's Grant in Reconstruction Georgia, 1865-1867.“ The Journal of Southern History 55, no. 4 (1989):597-632.

Cimbala, Paul A. und Miller, Randall M.. The Freedmen's Bureau and Reconstruction: Reconsiderations. New York: Fordham University Press, 1999.

Clark, Christopher M. The Sleepwalkers: How Europe Went to War in 1914. London, New York: Allen Lane, 2012.

Clark, Gordon L. und Wójcik, Dariusz. The Geography of Finance: Corporate Governance in the Global Marketplace. Oxford, New York: Oxford University Press, 2007.

Cleaver, Nick. Grover Cleveland's New Foreign Policy: Arbitration, Neutrality, and the Dawn of American Empire. New York: Palgrave MacMillan, 2014.

Clegg, Brian. The Man Who Stopped Time: The Illuminating Story of Eadweard Muybridge: Pioneer Photographer, Father of the Motion Picture, Murderer. Washington, DC: Joseph Henry Press, 2007.

Clements, Kendrick A. und Eric A. Cheezum. Woodrow Wilson. Washington, DC: CQ Press, 2003.

Cleveland, Frederick Albert und Powell, Fred Wilbur. Railroad Promotion and Capitalization in the United States. New York: Arno Press, 1981.

Clinton, Catherine. „Reconstructing Freedwomen.“ In: Catherine Clinton und Nina Silber (Hg.). Divided Houses: Gender and the Civil War. New York: Oxford University Press, 1992, S. $306-319$.

Clouatre, Doug. Presidential Upsets: Dark Horses, Underdogs, and Corrupt Bargains. Santa Barbara, CA: ABC-CLIO, 2013.

Coben, Stanley. A. Mitchell Palmer: Politician. New York: Da Capo Press, 1972.

Cochran, Robert T. „Cold-Eyed Soldier of Fortune Who Became a ,President'، Smithsonian 12, no. 3 (1981):117-28.

Cogliano, Francis D. Emperor of Liberty: Thomas Jefferson's Foreign Policy. New Haven, CT: Yale University Press, 2014.

Cohen, Daniel. The Alaska Purchase. Brookfield, CT: Millbrook Press, 1996.

Cohen, Miriam. Workshop to Office: Two Generations of Italian Women in New York City, 1900 -1950. Ithaca, NY: Cornell University Press, 1993.

Cohen, Nancy. The Reconstruction of American Liberalism, 1865-1914. Chapel Hill, NC: University of North Carolina Press, 2002.

Colby, Ira C. „The Freedmen's Bureau: From Social Welfare to Segregation.“ Phylon 46, no. 3 (1985):219-30.

Cole, J. Timothy. The Forest City Lynching of 1900: Populism, Racism, and White Supremacy in Rutherford County, North Carolina. Jefferson, NC: McFarland \& Co, 2003.

Coleman, James M. und Stone, Gregory W.. „James P. Morgan: Scientific Contributions.“ Journal of Coastal Research 14, no. 3 (1998):867-71. 
Collier, David. „Comment: QCA Should Set Aside the Algorithms.“ Sociological Methodology 44, (2014):122-126.

Collier, Ruth Berins und Collier, David. Shaping the Political Arena: Critical Junctures, the Labor Movement, and Regime Dynamics in Latin America. Notre Dame, IN: University of Notre Dame Press, 2002.

Collin, Richard H. Theodore Roosevelt, Culture, Diplomacy, and Expansion: A New View of American Imperialism. Baton Rouge, LA: Louisiana State University Press, 1985.

Collins, Charles Wallace. The Fourteenth Amendment and the States: A Study of the Operation of the Restraint Clauses of Section One of the Fourteenth Amendment to the Constitution of the United States. Clark, N): Lawbook Exchange, 2004.

Collins, Douglas. The Story of Kodak. New York: H.N. Abrams, 1990.

Collomp, Cathérine. Entre Classe et Nation: Mouvement Ouvrier et Immigration aux États-Unis 1880 -1920. Paris: Belin, 1998.

Collomp, Cathérine. „L’American Federation of Labor et la Politique Extérieures des États-Unis: De l’Antiimpérialism à la Coopération Idéologique.“ In: Serge Ricard und James Bolner (Hg.). La République Impérialiste: L’Expansionnisme et la Politique Extérieure des Etats-Unis, 1885-1909. Études et Documents. Aix-en-Provence: Université de Provence, 1987, S. $181-93$.

Conrad, Sebastian. What Is Global History? Princeton, NJ: Princeton University Press, 2016.

Conrad, Sebastian. und Osterhammel, Jürgen. Das Kaiserreich transnational: Deutschland in der Welt 1871-1914. Göttingen: Vandenhoeck \& Ruprecht, 2004.

Conrad, Sebastian., Randeria, Shalini und Sutterlüty, Beate. Jenseits des Eurozentrismus: Postkoloniale Perspektiven in den Geschichts- und Kulturwissenschaften. Frankfurt am Main, New York: Campus, 2002.

Conway, Lorie. Forgotten Ellis Island: The Extraordinary Story of America's Immigrant Hospital. New York: Smithsonian Books. Collins, 2007.

Cook, Adrian. The Alabama Claims: American Politics and Anglo-American Relations, 1865 -1872. Ithaca, NY: Cornell University Press, 1975.

Cook, Charles Orson (Hg.). Horatio Alger: Gender and Success in the Gilded Age. „Ragged Dick“ and „Tattered Tom“. Hoboken, NJ: Wiley-Blackwell, 2006.

Cooke, Alistair. Images of America: Selected Readings Based on Alistair Cooke’s America. New York: Knopf, 1978.

Cooling, Benjamin Franklin. Benjamin Franklin Tracy: Father of the Modern American Fighting Navy. Hamden, CT: Archon Books, 1973.

Cooling, Benjamin Franklin. Gray Steel and Blue Water Navy: The Formative Years of America's Military-Industrial Complex, 1881-1917. Hamden, CT: Archon Books, 1979.

Coontz, Stephanie, Parson, Maya und Raley, Gabrielle. American Families: A Multicultural Reader. New York: Routledge, 2008.

Cooper, Edward S. William Worth Belknap an American Disgrace. Madison NJ, London: Fairleigh Dickinson University Press. Associated University Presses, 2003.

Corey, Lewis. The House of Morgan: A Social Biography of the Masters of Money. New York: AMS Press, 1969.

Corner, Paul. „The Road to Fascism: An Italian Sonderweg?“ Contemporary European History 11, no. 2 (2002):273-95.

Correia, David. Properties of Violence: Law and Land Grant Struggle in Northern New Mexico. Athens, GA: University of Georgia Press, 2013. 
Cortada, James N. und Cortada, James W.. U.S. Foreign Policy in the Caribbean, Cuba, and Central America. New York: Praeger, 1985.

Cortada, James W. „Diplomatic Rivalry between Spain and the United States Over Chile and Peru, 1865-1871.“ Inter-American Economic Affairs 27 (1974):47-57.

Cortada, James W. Spain and the American Civil War Relations at Mid-Century, 1855-1868. Philadelphia, PA: American Philosophical Society, 1980.

Costin, Lela B. Two Sisters for Social Justice: A Biography of Grace and Edith Abbott. Urbana, IL: University of Illinois Press, 2003.

Cott, Nancy F. Root of Bitterness: Documents of the Social History of American Women. Boston, MA: Northeastern University Press, 1996.

Cottman, George S. „Old-Time Slums of Indianapolis.“ The Indiana Quarterly Magazine of History. 1911 Dec 1, 7 (4):170-173.

Cowan, Robin und Gunby, Philip. „Sprayed to Death: Path Dependence, Lock-in and Pest Control Strategies." The Economic Journal 1996, 106 (436):521-542.

Cox, Howard. The Global Cigarette: Origins and Evolution of British American Tobacco, 1880-1945. New York: Oxford University Press, 2000.

Cox, LaWanda. „The Promise of Land for the Freedmen.“ The Mississippi Valley Historical Review 45, no. 3 (1958): 413- 40.

Cox, LaWanda. Freedom, Racism, and Reconstruction: Collected Writings of LaWanda Cox. Athens, GA: University of Georgia Press, 1997.

Cox, Michael. „Empire by Denial: The Strange Case of the United States.“ International Affairs. 2005, 81(1):15- 30.

Craig, Reginald S. The Fighting Parson: The Biography of Colonel John M. Chivington. Los Angeles, LA: Westernlore Press, 1959.

Craig, Robert H. Religion and Radical Politics: An Alternative Christian Tradition in the United States. Philadelphia, PA: Temple University Press, 1992.

Crandall, Samuel B. Treaties: Their Making and Enforcement. Clark, NJ: Lawbook Exchange, 2005.

Crapol, Edward P. James G. Blaine: Architect of Empire. Wilmington, DE: Scholarly Resources, 2000.

Crapol, Edward P. Women and American Foreign Policy: Lobbyists, Critics, and Insiders. New York: Greenwood Press, 1987.

Crawford, Jay Boyd. The Credit Mobilier of America: Its Origin and History, Its Work of Constructing the Union Pacific Railroad and the Relation of Members of Congress Therewith. New York: AMS Press, 1971.

Crawford, Margaret. Building the Workingman's Paradise: The Design of American Company Towns. London, New York: Verso, 1995.

Cristobal, Adrian E. The Tragedy of the Revolution. Makati City, Philippines: Studio 5 Pub, 1997.

Crompton, Samuel Etinde. The Sinking of the USS Maine: Declaring War against Spain. New York: Chelsea House Publishers, 2009.

Cronon, Edmund David. Black Moses: The Story of Marcus Garvey and the Universal Negro Improvement Association. Madison, WI: University of Wisconsin Press, 1955.

Crook, D. P. Darwin's Coat-Tails: Essays on Social Darwinism. New York: Peter Lang, 2007.

Crouch, Barry A. „,All the Vile Passions': The Texas Black Code of 1866.“ The Southwestern Historical Quarterly 97, no. 1 (1993):12-34. 
Crouch, Barry A. The Freedmen's Bureau and Black Texans. Austin, TX: University of Texas Press, 1992.

Crouch, Barry A. „,To Enslave the Rising Generation“: The Freedmen's Bureau and the Texas Black Code.“ In: Cimbala, Paul Allan und Miller, Randall M. (Hg.). The Freedmen's Bureau and Reconstruction: Reconsiderations. New York: Fordham University Press, 1999, S. $261-87$.

Crow, Peter. Do, Die, or Get Along: A Tale of Two Appalachian Towns. Athens, GA: University of Georgia Press, 2007.

Cruikshank, Jeffrey L. und Schultz, Arthur W.. The Man Who Sold America: The Amazing (but True!) Story of Albert D. Lasker and the Creation of the Advertising Century. Boston, MA: Harvard Business Review Press, 2010.

Cruse, J. Brett. Battles of the Red River War: Archeological Perspectives on the Indian Campaign of 1874. College Station, TX: Texas A\&M University Press, 2008.

Culbertson, Margaret. „Mail-Order House and Plan Catalogues in the United States, 1876 -1930.“ Art Documentation: Journal of the Art Libraries Society of North America. 1992, 11 (1):17- 20.

Currarino, Rosanne. The Labor Question in America: Economic Democracy in the Gilded Age. Urbana, IL: University of Illinois Press, 2011.

Currell, Susan und Cogdell, Christina. Popular Eugenics: National Efficiency and American Mass Culture in the 1930s. Athens, OH: Ohio University Press, 2006.

Current, Richard Nelson. Those Terrible Carpetbaggers. New York: Oxford University Press, 1988.

Curtis, O. B. und Gergel, Patricia M.. The History of the National Council of Examiners for Engineering and Surveying, 1920-2004. Clemson, SC: National Council of Examiners for Engineering and Surveying, 2004.

Cushman, Gregory T. Guano and the Opening of the Pacific World a Global Ecological History. Cambridge, New York: Cambridge University Press, 2013.

Cutler, Bruce. The Massacre at Sand Creek: Narrative Voices. Norman, OK: University of Oklahoma Press, 1995.

Cutler, Irving. Chicago, Metropolis of the Mid-Continent. Carbondale, IL: Southern Illinois University Press, 2006.

Czitrom, Daniel. „Underworlds and Underdogs: Big Tim Sullivan and Metropolitan Politics in New York, 1889-1913.“ In: Raymond A. Mohl (Hg.). The Making of Urban America. Wilmington, DE: Scholarly Resources, 1988, S. 131-51.

Dahl, Eric J. „Naval Innovation: From Coal to Oil.“ Joint Force Quarterly 27 (2000-2001):50-56.

Dallek, Robert. The American Style of Foreign Policy: Cultural Politics and Foreign Affairs. New York: Knopf. Distributed by Random House, 1983.

Danaher, Kevin und Mark, Jason. Insurrection: Citizen Challenges to Corporate Power. New York: Routledge, 2003.

Daniels, Roger. The Politics of Prejudice: The Anti-Japanese Movement in California and the Struggle for Japanese Exclusion. Berkeley, CA: University of California Press, 1977.

Dauphine, James G. „The Knights of the White Camelia and the Election of 1868: Louisiana's White Terrorists, A Benighting Legacy. “ Louisiana History: The Journal of the Louisiana Historical Association 30, no. 2 (1989):173-90. 
Dautrich, Kenneth und Yalof, David Alistair. American Government Historical, Popular \& Global Perspectives. Belmont, CA: Wadsworth Cengage Learning, 2009.

David, Paul A. „Clio and the Economics of QWERTY.“ The American Economic Review 75, no. 2 (1985):332-37.

David, Paul A. Path Dependence and the Quest for Historical Economics: One More Chorus of the Ballad of QWERTY. Oxford: Nuffield College, 1997.

David, Paul A. „Path Dependence, Its Critics and the Quest for ,Historical Economics““. In: Hodgson, Geoffrey Martin (Hg.). The Evolution of Economic Institutions: A Critical Reader. Cheltenham, Northampton, MA: Edward Elgar, 2007, S. 120-144.

David, Paul A. „,Why Are Institutions the Carriers of History”? Path Dependence and the Evolution of Conventions, Organizations and Institutions." Structural Change and Economic Dynamics. 1994, 5 (2):205-220.

Davies, Hannah Catherine. „Transatlantic Speculations: A Transnational and Comparative History of the Panics of 1873.“ Dissertation Freie Universität Berlin, 2014.

Davis, Clark. Company Men: White-Collar Life and Corporate Cultures in Los Angeles, 1892-1941. Baltimore, MD: Johns Hopkins University Press, 2000.

Davis, Horace B. „American Labor and Imperialism Prior to World War I.“ Science \& Society 27, no. 1 (1963):70-76.

Davis, J. C. Bancroft. Mr. Fish and the Alabama Claims: A Chapter in Diplomatic History. Freeport, NY: Books for Libraries Press, 1969.

Davis, John Martin und Tremmel, George B. Parole, Pardon, Pass and Amnesty Documents of the Civil War: An Illustrated History. Jefferson, NC, London: McFarland, 2014.

Davis, Margaret Leslie. Dark Side of Fortune: Triumph and Scandal in the Life of Oil Tycoon Edward L. Doheny. Berkeley, CA: University of California Press, 1998.

Davis, Michelle Bray und Rollin W. Quimby. „Senator Proctor's Cuban Speech: Speculations on a Cause of the Spanish-American War." Quarterly Journal of Speech, no. 55 (1969):131- 41.

Davis, Thomas J. Plessy v. Ferguson. Santa Barbara, CA: Greenwood, 2012.

Dawson, Andrew. „The Paradox of Dynamic Technological Change and the Labor Aristocracy in the United States, 1880-1914." Labor History 20 (1979):325-51.

Dawson, Joseph G. Army Generals and Reconstruction: Louisiana, 1862-1877. Baton Rouge, LA: Louisiana State University Press, 1982.

Dedinger, Beatrice. „The Franco-German Trade Puzzle: An Analysis of the Economic Consequences of the Franco-Prussian War.“ The Economic History Review 65, no. 3 (2012):1029-1054.

De Genova, Nicholas. Racial Transformations: Latinos and Asians Remaking the United States. Durham, NC: Duke University Press, 2006.

De Landa, Manuel. A Thousand Years of Nonlinear History. New York: Zone Books, 1997.

De Testa, Maria und Gautier, Antoine. „Le Diplomate Russe Edouard de Stoeckl (ca. 1805-1892) et la Cession de l’Alaska aux États-Unis.“ In : Dies. Drogmans et Diplomates Européens auprès de la Porte Ottomane. Instanbul: ISIS, 2003, S. 463-469.

Dean, John W. Warren G. Harding. New York: Times Books, 2004.

Dearborn, Mary V. Mistress of Modernism: The Life of Peggy Guggenheim. Boston, MA, New York: Houghton Mifflin, 2004.

Debs, Eugene V. und Constantine, J. Robert. Letters of Eugene V. Debs. Urbana, IL: University of Illinois Press, 1990. 
Decker, Julio. „The Immigration Restriction League and the Political Regulation of Immigration, 1894-1924.“ Dissertation University of Leeds, 2012.

Decker, Julio. „The Transnational Biopolitics of Whiteness and Immigration Restriction in the United States, 1894-1924.“ In: Lehmkuhl, Ulla , Bischoff, Eva und Finzsch, Norbert (Hg.). Provincializing the United States: Colonialism, Decolonization, and (Post)Colonial Governance in Transnational Perspective. Heidelberg: Winter, 2014, S. 121-153.

DeConde, Alexander. A History of American Foreign Policy. New York: Scribner, 1978.

Dehler, Gregory J. Chester Alan Arthur: The Life of a Gilded Age Politician and President. New York: Nova Science Publishers, 2011.

Deleuze, Gilles. Logik des Sinns. Frankfurt/Main: Suhrkamp, 1993.

Deleuze, Gilles. Logique du Sens. Paris: Éditions de Minuit, 1969.

Deleuze, Gilles. Pourparlers: 1972-1990. Paris: Editions de Minuit, 1990.

Deleuze, Gilles und Félix Guattari. Anti-Ödipus: Kapitalismus und Schizophrenie I. Frankfurt/Main: Suhrkamp, 1977.

Deleuze, Gilles und Félix Guattari. A Thousand Plateaus: Capitalism and Schizophrenia. Minneapolis, MN: University of Minnesota Press, 1987.

Deleuze, Gilles und Félix Guattari. Was Ist Philosophie? Frankfurt/Main: Suhrkamp, 2000.

Deleuze, Gilles und Félix Guattari. What Is Philosophy? New York, London: Verso, 1994.

Deleuze, Gilles und Félix Guattari. Tausend Plateaus: Kapitalismus und Schizophrenie II. Berlin: 1992.

Delfino, Susanna und Gillespie, Michele. Global Perspectives on Industrial Transformation in the American South. Columbia, MO: University of Missouri Press, 2005.

Dell, Pamela. Wilma Mankiller: Chief of the Cherokee Nation. Minneapolis, MN: Compass Point Books, 2006.

Demarest, David P. und Weingartner, Fannia. „The River Ran Red“ Homestead 1892. Pittsburgh: University of Pittsburgh Press, 1992.

DeMille, Anna George. „Henry George: The '86 Mayoralty Campaign.“ American Journal of Economics and Sociology 5, no. 2 (1946):247-60.

Dennis, Bernard G. American Civil Engineering History: The Pioneering Years. Proceedings of the Fourth National Congress on Civil Engineering History and Heritage, November 2-6, 2002.Washington, DC, Reston, VA: American Society of Civil Engineers, 2003.

Denson, John V. Reassessing the Presidency: The Rise of the Executive State and the Decline of Freedom. Auburn, AL: Mises Institute, 2001.

Dent, David W. The Legacy of the Monroe Doctrine: A Reference Guide to U.S. Involvement in Latin America and the Caribbean. Westport, CT: Greenwood Press, 1999.

Derickson, Alan. Black Lung: Anatomy of a Public Health Disaster. Ithaca, NY: Cornell University Press, 1998.

Derickson, Alan. Workers' Health, Workers' Democracy: The Western Miners' Struggle, 1891-1925. Ithaca, NY: Cornell University Press, 1988.

Deverell, William Francis und David Igler. A Companion to California History. Chichester, Malden, MA: Wiley-Blackwell, 2008.

Dickerson, Dennis C. Out of the Crucible: Black Steelworkers in Western Pennsylvania, 1875-1980. Albany, NY: State University of New York Press, 1986.

Dickinson, Joan Younger. The Role of the Immigrant Women in the U.S. Labor Force, 1890-1910. New York: Arno Press, 1980. 
Dighe, Ranjit S. The Historian's Wizard of Oz: Reading L. Frank Baum's Classic as a Political and Monetary Allegory. Westport, CT: Praeger, 2002.

DiMarco, Louis A. Anatomy of a Failed Occupation: The U.S. Army in the Former Confederate States, 1865 to 1877. Arlington, VA: The Land Warfare Papers. A National Security Affairs Paper Published on Occasion by the Institute of Land Warfare, 2007.

Diner, Hasia R. The Jews of the United States, 1654 to 2000. Berkeley, CA: University of California Press, 2004.

Dinneen, Joseph F. Ward Eight. New York: Arno Press, 1976.

DiSalvo, Daniel. Engines of Change: Party Factions in American Politics, 1868-2010. New York: Oxford University Press, 2012.

Dobie, J. Frank. The Longhorns. Austin, TX: University of Texas Press, 2000.

Dobkowski, Michael N. The Tarnished Dream: The Basis of American Anti-Semitism. Westport, CT: Greenwood Press, 1979.

Dobson, John M. Bulls, Bears, Boom, and Bust: A Historical Encyclopedia of American Business Concepts. Santa Barbara, CA: ABC-CLIO, 2007.

Dobson, John M. Reticent Expansionism: The Foreign Policy of William McKinley. Pittsburgh, PA: Duquesne University Press, 1988.

Dodge, Grace H. Grace H. Dodge: Her Life and Work. New York: Arno Press, 1974.

Dolfsma, Wilfred. Institutions, Communication and Values. Basingstoke, New York: Palgrave Macmillan, 2009.

Dolkart, Andrew. Biography of a Tenement House in New York City: An Architectural History of 97 Orchard Street. Santa Fe, NM: The Center for American Places, 2006.

Donald, David Herbert. Charles Sumner and the Coming of the Civil War. Naperville, IL: Sourcebooks, 2009.

Donald, David Herbert. Lincoln. New York: Simon \& Schuster, 1995.

Donhardt, Gary L. In the Shadow of the Great Rebellion: The Life of Andrew Johnson, Seventeenth President of the United States (1808-1875). New York: Nova Science Publishers, 2007.

Dougherty, Kevin. The Port Royal Experiment: A Case Study in Development. Jackson, MS: University Press of Mississippi, 2014.

Dougherty, Michael. To Steal a Kingdom. Waimanalo, HI: Island Press, 1992.

Dougill, J. W. „Path Dependence and a General Theory for the Progressively Fracturing Solid.“ Proceedings of the Royal Society of London. Series A, Mathematical and Physical Sciences. 1983, 390 (1799):341-351.

Doyle, Michael W. Empires. Ithaca, NY: Cornell University Press, 1986.

Dozer, Donald Marquand. The Monroe Doctrine, Its Modern Significance. Tempe: Center for Latin American Studies, Arizona State University, 1976.

Dray, Philip. There Is Power in a Union: The Epic Story of Labor in America. New York: Doubleday, 2010.

Dreesen, Philipp, Kumiega, Lukasz und Spieß, Constanze (Hg.). Mediendiskursanalyse: Diskurse, Dispositive, Medien, Macht. Berlin: Springer, 2014.

Dreher, Martin Norberto, Greisi Fabiane Griesang Jung, Miquéias Henrique Mugge, and Keity Link Seifert. Degredados de Mecklenburg-Schwerin e os Primórdios da Imigraçao Alema No Brasil. São Leopoldo: Oikos Editora, 2010.

Dresden, Donald W. The Marquis de Morès: Emperor of the Bad Lands. Norman, OK: University of Oklahoma Press, 1970. 
Du Bois, Cora Alice. The 1870 Ghost Dance. Lincoln, NE: University of Nebraska Press, 2007. Du Bois, W. E. B. Black Reconstruction in America, 1860-1880. New York: Atheneum, 1973. Dubofsky, Melvyn. Industrialism and the American Worker, 1865-1920. Wheeling, IL: H. Davidson, 1996.

Dubofsky, Melvyn. „The Origins of Western Working-Class Radicalism, 1890-1905.“In: Daniel J. Leab (Hg.). The Labor History Reader. Urbana, IL: University of Illinois Press, 1985, S. $230-253$.

Dubofsky, Melvyn und McCartin, Joseph Anthony. We Shall Be All: A History of the Industrial Workers of the World. Urbana, IL: University of Illinois Press, 2000.

Dudden, Faye E. Serving Women: Household Service in Nineteenth-Century America. Middletown, CT, Scranton, PA: Wesleyan University Press. Distributed by Harper \& Row, 1983.

Due, John F. Government versus Private Financing of the Railroad Industry. Transportation Journal. 1982, 21 (3):16-21.

Dunlavy, Colleen A. Politics and Industrialization: Early Railroads in the United States and Prussia. Princeton, NJ: Princeton University Press, 1994.

Dunn, Joeming W. und Espinosa, Rod. Ulysses S. Grant: 18th U.S. President. Edina, MN: Magic Wagon, 2012.

Dunn, Stephen Porter. The Fall and Rise of the Asiatic Mode of Production. London, Boston: Routledge \& Kegan Paul, 1982.

Dunn, William R. „I stand by Sand Creek“: A Defense of Colonel John M. Chivington and the Third Colorado Cavalry. Fort Collins, CO: Old Army Press, 1985.

DuPuis, Steven und Silva, John. Package Design Workbook: The Art and Science of Successful Packaging. Beverly, MA: Rockport Publishers, 2008.

Durden, Robert Franklin. The Dukes of Durham, 1865-1929. Durham, NC: Duke University Press, 1975.

Dyer, Davis, Dalzell, Frederick und Olegario, Rowena. Rising Tide: Lessons from 165 Years of Brand Building at Procter \& Gamble. Boston, MA: Harvard Business School Press, 2004.

Easton, Susan. „Electing the Electorate: The Problem of Prisoner Disenfranchisement.“ The Modern Law Review 69, no. 3 (2006):443-52.

Ebke, Werner F. „Interlocking Directorates.“ Zeitschrift für Unternehmens- und Gesellschaftsrecht 19, no. 1 (1990):50-109.

Edmo, William D. History and Culture of the Boise Shoshone and Bannock Indians. Pittsburgh, PA: Dorrance Publishing Co., 2010.

Edsforth, Ronald und Larry Bennett. Popular Culture and Political Change in Modern America. Albany NY: State University of New York Press, 1991.

Edwards, Laura F. „Sexual Violence, Gender, Reconstruction, and the Extension of Patriarchy in Granville County, North Carolina.“ The North Carolina Historical Review 68, no. 3 (1991):237-60.

Edwards, Laura F. „The Problem of Dependency: African Americans, Labor Relations, and the Law in the Nineteenth-Century South.“ Agricultural History 72, no. 2 (1998):313-40.

Edwards, Linda McMurry. George Washington Carver, Scientist and Symbol. New York: Oxford University Press, 1981.

Edwards, Rebecca. New Spirits: Americans in the Gilded Age, 1865-1905. New York: Oxford University Press, 2006.

Edwards, Stewart. The Paris Commune 1871. London: Eyre and Spottiswoode, 1971. 
Edwards, Wendy J. Deichmann und De Swarte Gifford, Carolyn. Gender and the Social Gospel. Urbana, IL: University of Illinois Press, 2003.

Eggert, Gerald G. Richard Olney: Evolution of a Statesman. University Park: Pennsylvania State University Press, 1974.

Eggert, Gerald G. Steelmasters and Labor Reform, 1886-1923. Pittsburgh, PA: University of Pittsburgh Press, 1981.

Eggertsson, Thrainn. „The Economics of Institutions: Avoiding the Open-Field Syndrome and the Perils of Path Dependence." Acta Sociologica 1993, 36 (3):223-237

Egnal, Marc. Clash of Extremes: The Economic Origins of the Civil War. New York: Hill and Wang, 2009.

Eisenach, Eldon J. The Social and Political Thought of American Progressivism. Indianapolis, IN: Hackett Pub, 2006.

Eisenstark, Reyna, Friedenthal, Lora, and Weber, Jennifer L.. Progressivism. New York: Chelsea House, 2009.

Eland, Ivan. The Empire Has No Clothes: U.S. Foreign Policy Exposed. Oakland, CA: The Independent Institute, 2008.

Eland, Ivan. Putting „Defense“ back into U.S. Defense Policy: Rethinking U.S. Security in the Post-Cold War World. Westport, CT: Praeger, 2001.

Eller, Ronald D. Miners, Millhands, and Mountaineers: Industrialization of the Appalachian South, 1880-1930. Knoxville, TN: University of Tennessee Press, 1982.

Elliott, Claude. „The Freedmen's Bureau in Texas.“ The Southwestern Historical Quarterly 56, no. 1 (1952):1-24.

Elliott, Lawrence. George Washington Carver: The Man Who Overcame. Englewood Cliffs, NJ: Prentice-Hall, 1966.

Elliott, Mark. Color-Blind Justice: Albion Tourgée and the Quest for Racial Equality from the Civil War to Plessy v. Ferguson. Oxford, New York: Oxford University Press, 2006.

Ellis, Elmer. Henry Moore Teller: Defender of the West. Caldwell, ID: The Caxton Printers, Ltd, 1941.

Ellis, Richard. The Development of the American Presidency. New York: Routledge, 2012.

Elsässer, Jürgen. Der Deutsche Sonderweg: Historische Last und politische Herausforderung. Kreuzlingen: Diederichs, 2003.

Engle, Stephen Douglas. Struggle for the Heartland: The Campaigns from Fort Henry to Corinth. Lincoln, NE: University of Nebraska Press, 2001.

Engs, Robert Francis und Randall M. Miller. The Birth of the Grand Old Party: The Republicans' First Generation. Philadelphia, PA: University of Pennsylvania Press, 2002.

Epps, Garrett. Democracy Reborn: The Fourteenth Amendment and the Fight for Equal Rights in Post-Civil War America. New York: H. Holt, 2006.

Epstein, Lawrence J. At the Edge of a Dream: The Story of Jewish Immigrants on New York's Lower East Side 1880-1920. San Francisco, CA: Jossey-Bass, 2007.

Ernst, Joseph W. Hg. Dear Father/Dear Son: Correspondence of John D. Rockefeller and John D. Rockefeller, Jr. New York: Fordham University Press, 1994.

Escott, Paul D. Major Problems in the History of the American South: Documents and Essays. Boston, MA: Houghton Mifflin, 1999.

Escott, Paul D. und David R. Goldfield. Major Problems in the History of the American South: Documents and Essays. Lexington, MA: D.C. Heath, 1990. 
Estlund, Cynthia and Wachter, Michael L. (Hg.) Research Handbook on the Economics of Labor and Employment Law. Cheltenham, Northampton, MA: Edward Elgar, 2012

Esty, Amos. Plessy v. Ferguson. Greensboro, N.C: Morgan Reynolds Pub, 2012.

Evans, David C. Custer's Last Fight: The Story of the Battle of the Little Big Horn. El Segundo, CA: Upton \& Sons, 1999.

Evans, Harold, Buckland, Gail und Baker, Kevin. The American Century. New York: Knopf, 1998.

Evans, Sara M. Born for Liberty: A History of Women in America. New York, London: Free Press. Collier Macmillan, 1989.

Everly, Elaine C. „Marriage Registers of Freedmen.“ Prologue 5, no. 3 (1973):150-154.

Ewald, Alec C. „Criminal Disenfranchisement and the Challenge of American Federalism.“ Publius 39, no. 3 (2009):527-56.

Fagg, John Edwin. Pan Americanism. Malabar, FL: R.E. Krieger Pub. Co, 1982.

Fahs, Alice und Joan Waugh. The Memory of the Civil War in American Culture. Chapel Hill: University of North Carolina Press, 2004.

Fairclough, Adam. „,Forty Acres and a Mule‘: Horace Mann Bond and the Lynching of Jerome Wilson.“ Journal of American Studies 31, no. 1 (1997):1-17.

Fallin, Wilson. The African American Church in Birmingham, Alabama, 1815-1963: A Shelter in the Storm. New York: Garland Pub, 1997.

Falzone, Vincent J. Terence V. Powderly: Middle Class Reformer. Washington, DC: University Press of America, 1978.

Farhat, Nadim. „Le Conflit Communautaire Belge entre Contigence Identitaire et de Terminisme Historique: Analayse de ,Path Dependence de la Formation des Communautés et des Trajectoires Institutionelles.“ Revue Française de Science Politique. 2012, 62 (2):231-254.

Farmer-Kaiser, Mary. Freedwomen and the Freedmen's Bureau: Race, Gender, and Public Policy in the Age of Emancipation. New York: Fordham University Press, 2010.

Farmer-Kaiser, Mary. „,With a Weight of Circumstances like Millstones about Their Necks': Freedwomen, Federal Relief, and the Benevolent Guardianship of the Freedmen's Bureau." The Virginia Magazine of History and Biography 115, no. 3 (2007):412-42.

Farmer, Mary J. „,Because They Are Women“: Gender and the Virginia Freedmen's Bureau's „War on Dependency.“ In: Paul A. Cimbala und Randall M. Miller (Hg.). The Freedmen's Bureau and Reconstruction: Reconsiderations. New York: Fordham University Press, 1999, S. 161-192.

Farquhar, Michael. A Treasury of Foolishly Forgotten Americans: Pirates, Skinflints, Patriots, and Other Colorful Characters Stuck in the Footnotes of History. New York: Penguin Books, 2008.

Farrell, James J. One Nation under Goods: Malls and the Seductions of American Shopping. Washington, DC: Smithsonian Books, 2010.

Faulkner, Carol. Lucretia Mott's Heresy: Abolition and Women's Rights in Nineteenth-Century America. Philadelphia, PA: University of Pennsylvania Press, 2011.

Faulkner, Harold Underwood. The Decline of Laissez Faire, 1897-1917. Armonk, NY: M. E. Sharpe, Inc, 1989.

Faulkner, Harold Underwood. Politics, Reform, and Expansion: 1890-1900. New York: Harper, 1959.

Feimster, Crystal Nicole. Southern Horrors: Women and the Politics of Rape and Lynching. Cambridge, MA: Harvard University Press, 2009. 
Feldman, Glenn. The Irony of the Solid South Democrats, Republicans, and Race, 1865-1944. Tuscaloosa: The University of Alabama Press, 2013.

Fellman, Michael. Citizen Sherman: A Life of William Tecumseh Sherman. New York: Random House, 1995.

Ferguson, Kathy E. Emma Goldman: Political Thinking in the Streets. Lanham, MD: Rowman \& Littlefield Publishers, 2011.

Ferguson, Niall. Virtual History: Alternatives and Counterfactuals. New York: Basic Books, 1999. Ferguson, Niall. Colossus: The Price of America’s Empire. New York: Penguin Press, 2004. Ferguson, Niall. „An Empire in Denial: The Limits of US Imperialism.“ Harvard International Review. 2003, 25 (3):64-69.

Ferguson, Robert A. The Trial in American Life. Chicago: University of Chicago Press, 2007. Fernald, James Champlin. The Imperial Republic. New York, London: Funk \& Wagnalls Company, 1898.

Ferrell, Claudine L. Reconstruction. Westport, CT: Praeger, 2003.

Feuer, A. B. America at War: The Philippines, 1898-1913. Westport, CT: Praeger, 2002.

Fiebig-von Hase, Ragnhild. „Amerikanische Friedensbemühungen in Europa, 1905-1914.“ In: Norbert Finzsch und Hermann Wellenreuther. Liberalitas: Festschrift für Erich Angermann zum 65. Geburtstag. Stuttgart: F. Steiner, 1992, S. 285-318.

Fiebig-von Hase, Ragnhild. „Imperialismus als ,Sicherheitspolitik': Die Okkupation Haitis durch die USA im Sommer 1915.“ In: Felix Becker, Holger Meding und Barbara Potthast (Hg.). Iberische Welten: Festschrift zum 65. Geburtstag von Günter Kahle. Köln, Weimar, Wien: Böhlau Verlag, 1994, S. 219-241.

Fiebig-von Hase, Ragnhild. Lateinamerika als Konfliktherd der deutsch-amerikanischen Beziehungen, 1890-1903: Vom Beginn der Panamerikapolitik bis zur Venezuelakrise von 1902/03. Göttingen: Vandenhoeck \& Ruprecht, 1986.

Field, Ron und Bielakowski, Alexander M.. Buffalo Soldiers: African American Troops in the US Forces, 1866-1945. Oxford, New York: Osprey Pub, 2008.

Filler, Louis. Muckraking and Progressivism in the American Tradition. New Brunswick, N): Transaction Publishers, 1996.

Fink, Leon. The Long Gilded Age: American Capitalism and the Lessons of a New World Order. Philadelphia, PA: University of Pennsylvania Press, 2015.

Fink, Leon. Major Problems in the Gilded Age and the Progressive Era: Documents and Essays. Boston, MA: Houghton Mifflin, 2001.

Fink, Leon. Workingmen's Democracy: The Knights of Labor and American Politics. Urbana, IL: University of Illinois Press, 1983.

Finkelman, Paul. Encyclopedia of African American History, 1619-1895: From the Colonial Period to the Age of Frederick Douglass. New York: Oxford University Press, 2006.

Finkelman, Paul. Encyclopedia of the United States in the Nineteenth Century. New York: Charles Scribner's Sons, 2001.

Finley, Randy. From Slavery to Uncertain Freedom: The Freedmen's Bureau in Arkansas, 1865-1869. Fayetteville, AK: University of Arkansas Press, 1996.

Finzsch, Norbert. „,The Aborigines... Were Never Annihilated, and Still They Are Becoming Extinct': Settler Imperialism and Genocide in Nineteenth-Century America and Australia.“ In: A. Dirk Moses (Hg.) Empire, Colony, Genocide: Conquest, Occupation, and Subaltern Resistance in World History. New York: Berghahn Books, 2008, S. 253-270. 
Finzsch, Norbert. (Hg.). Clios Natur: Vergleichende Aspekte der Umweltgeschichte. Berlin, Münster, Hamburg, New York: LIT, 2008.

Finzsch, Norbert. Die Goldgräber Kaliforniens: Arbeitsbedingungen, Lebensstandard und politisches System um die Mitte des 19. Jahrhunderts. Göttingen: Vandenhoeck \& Ruprecht, 1982.

Finzsch, Norbert. „Discourses of Genocide in Eighteenth- and Nineteenth-Century America and Australia.“ Genderforum (Rac(e)Ing Questions II: Gender and Postcolonial/Intercultural Issues) 10 (2005).

Finzsch, Norbert. „,Einige unserer Fabriken sind geschlossen worden und andere haben ihre Arbeiter entlassen': Die Rezession der 1870er Jahre und die Industriearbeiter San Franciscos - Eine Analyse der Arbeitsstättenzählungen von 1870 und 1880.“ Amerikastudien/American Studies 31 (1987):453-468.

Finzsch, Norbert. „The End of Slavery, the Role of the Freedmen's Bureau and the Introduction of Peonage.“ In: Ulrike Schmieder (Hg.). The End of Slavery in Africa and the Americas: A Comparative Approach. Berlin: LIT Verlag, 2011, S. 141-163.

Finzsch, Norbert. „Henry Adams, Nikola Tesla and the ,Body Electric': Intersections between Bodies and Electrical Machines.“In: Hampf, M. Michaela Hampf und Snyder-Körber, MaryAnn (Hg.). Machine: Bodies, Genders, Technologies. Heidelberg: Winter, 2012, S. $253-278$.

Finzsch, Norbert. „History as a Bag of Tricks We Play on the Dead: Theorien der Narrativität in der anglo-amerikanischen Historiographie der letzten 20 Jahre.“ Jahrbuch für Geschichte von Staat, Wirtschaft und Gesellschaft Lateinamerikas 35 (1998):245-73.

Finzsch, Norbert. „Introduction.“ In: Norbert Finzsch und Hermann Wellenreuther (Hg.). Visions of the Future in Germany and America. Oxford, New York: Berg Publishers, 2001, S. 1-21.

Finzsch, Norbert. „,It Is Scarcely Possible to Conceive That Human Beings Could Be So Hideous and Loathsome': Discourses of Genocide in Eighteenth and Nineteenth-Century America and Australia.“ Patterns of Prejudice 39, no. 2 (2005):97-115.

Finzsch, Norbert. Konsolidierung und Dissens: Nordamerika von 1800 bis 1865 . Münster: LIT, 2005.

Finzsch, Norbert. „Krise und „Rasse“: Wie Hypersegregation strukturellen Rassismus erzeugt.“ In: Andreas Etges und Winfried Fluck (Hg.). American Dream? Eine Weltmacht in der Krise. Franfurt/Main, New York: Campus, 2011, S. 177-194.

Finzsch, Norbert. „Reconstruction and ,Wiederaufbau' in German and American Perspective: Some Remarks on the Comparison of Singular Developments, ,Sonderweg' and Exceptionalism.“ In: Finzsch, Norbert und Martschukat, Jürgen (Hg.). Different Restorations: Reconstruction und „Wiederaufbau“ in the United States and Germany: 1865-1945-1989. Providence, RI, Oxford: Berghahn, 1996, S. 1-24.

Finzsch, Norbert. „Siedlerimperialismus und Genozid in den Vereinigten Staaten und Australien.“ In: Hartmut Lehmann und Claudia Schnurmann (Hg.). Atlantic Understandings: Essays on European and American History in Honor of Hermann Wellenreuther. Münster: LIT Verlag, 2006, S. 271-285.

Finzsch, Norbert. „Wissenschaftlicher Rassismus in den Vereinigten Staaten, 1850 bis 1930.“ In: Heidrun Kaupen-Haas und Christian Saller (Hg.). Wissenschaftlicher Rassismus: Analysen einer Kontinuität in den Human- und Naturwissenschaften. Frankfurt, New York: Campus, 1999, S. 84-110. 
Finzsch, Norbert. „,[...] Extirpate or Remove That Vermine: Genocide, Biological Warfare, and Settler Imperialism in the Eighteenth and Early Nineteenth Century.“ Journal of Genocide Research 10, no. 2 (2008):215-232.

Finzsch, Norbert., Horton, James Oliver und Horton, Lois E. Horton. Von Benin nach Baltimore: Die Geschichte der African Americans. Hamburg: Hamburger Edition, 1999.

Finzsch, Norbert. und Martschukat, Jürgen. Different Restorations: Reconstruction and „Wiederaufbau“ in Germany and the United States, 1865, 1945, and 1989. Providence, RI, Oxford: Berghahn Books, 1996.

Finzsch, Norbert und Wellenreuther, Hermann. Liberalitas: Festschrift für Erich Angermann zum 65. Geburtstag. Stuttgart: F. Steiner, 1992.

Fioretos, Orfeo, Falletti, Tulia G. und Sheingate, Adam. The Oxford Handbook of Historical Institutionalism. Oxford, New York: Oxford University Press, 2016.

Fischer, Fritz. Germany’s Aims in the First World War. New York: W. W. Norton, 1967.

Fischer, Fritz. Griff nach Der Weltmacht: Die Kriegszielpolitik des kaiserlichen Deutschland 1914/18. Düsseldorf: Droste, 1961.

Fisher, Christopher T. Nation Building and the Vietnam War. Pacific Historical Review. 2005, 74 (3):441- 456.

Fisher, Christopher T. The Illusion of Progress. Pacific Historical Review. 2006, 75 (1):25-51.

Fitzgerald, Michael W. Splendid Failure: Postwar Reconstruction in the American South.

Chicago, IL: Ivan R. Dee, 2007.

Fitzgerald, Michael W. „,To Give Our Votes to the Party': Black Political Agitation and Agricultural Change in Alabama, 1865-1870." The Journal of American History 76, no. 2 (1989):489-505.

Fitzpatrick, Peter. „Righteous Empire.“ Unbound. 2006, 2:1-18.

Fitzpatrick, Peter und Joyce, Richard. „The Normality of the Exception in Democracy's Empire.“ Journal of Law and Society 2007, 34 (1):65-76.

Flack, Horace Edgar. The Adoption of the Fourteenth Amendment. Buffalo, NY: W.S. Hein, 2003.

Fleegler, Robert L. Ellis Island Nation: Immigration Policy and American Identity in the Twentieth Century. Philadelphia, PA: University of Pennsylvania Press, 2013.

Fleming, Walter L. Civil War and Reconstruction in Alabama. New York: The Columbia University Press, 1905.

Fleming, Walter L. „Forty Acres and a Mule.“ The North American Review. 1906, 182 (594):721-737.

Fletcher, John Gould. Arkansas. Chapel Hill: Univ. of North Carolina Press, 1947.

Flynn, Dennis 0. und Giraldez, Arturo. „Path Dependence, Time Lags and the Birth of Globalisation: A Critique of O'Rourke and Williamson." European Review of Economic History. 2004, 8 (1):81-108.

Flynn, Thomas R. „Foucault as Philosopher of the Historical Event.“ In: Marc Rölli (Hg.). Ereignis auf Französisch: Von Bergson bis Deleuze. München: Wilhelm Fink, 2004, S. $209-234$.

Flynn, Thomas R. Sartre, Foucault, and Historical Reason. Chicago, IL: University of Chicago Press, $1997-2005$.

Fogel, Robert William. Railroads and American Economic Growth: Essays in Econometric History. Baltimore, MD: Johns Hopkins Press, 1964.

Fogel, Robert William. The Union Pacific Railroad: A Case in Premature Enterprise. Baltimore, MD: Johns Hopkins Press, 1960. 
Fogelson, Robert M. Bourgeois Nightmares: Suburbia, 1870-1930. New Haven, CT: Yale University Press, 2005.

Fogelson, Robert M. The Great Rent Wars: New York City, 1917-1929. New Haven, CT: Yale University Press, 2013.

Folsom, Franklin. America before Welfare. New York: NYU Press, 1996.

Foner, Eric. Free Soil, Free Labor, Free Men: The Ideology of the Republican Party before the Civil War. Oxford, New York: Oxford University Press, 1995

Foner, Eric. Reconstruction: America's Unfinished Revolution, 1863-1877. New York: Perennial Classics, 2002.

Foner, Eric. A Short History of Reconstruction, 1863-1877. New York: Harper \& Row, 1990.

Foner, Eric und Joshua Brown. Forever Free: The Story of Emancipation and Reconstruction. New York: Knopf, 2005.

Foner, Philip Sheldon. The Great Labor Uprising of 1877. New York: Monad Press: distributed by Pathfinder Press, 1977.

Foner, Philip Sheldon. History of the Labor Movement in the United States. New York: International Publishers, 1975.

Foner, Philip Sheldon. The Workingmen's Party of the United States: A History of the First Marxist Party in the Americas. Minneapolis, MN: MEP Publications, 1984.

Forbath, William E. Law and the Shaping of the American Labor Movement. Cambridge, MA: Harvard University Press, 1991.

Foreign Policy Association und Joseph Jr. Nye. „Global Q\&A: The Paradox of American Power: A Conversation with Joseph Nye Jr.“ [Web Page]: http://www.fpa.org/topics_info2414/ topics_info_show.htm?doc_id=103659. Gesehen am 9.7.2015.

Forman-Brunell, Miriam. Girlhood in America: An Encyclopedia. Santa Barbara, CA: ABC-CLIO, 2001.

Foucault, Michel. Dits et Ècrits, 1954-1988. Paris: Gallimard, 1994. 4 Bände.

Foucault, Michel. „Qu'est-ce qu’un auteur?“ Michel Foucault. Dits et Écrits, 1954-1988. Paris: Gallimard, 1994, Band 1, S. 789-821.

Foucault, Michel. „Theatrum Philosophicum.“ In: Gilles Deleuze und Michel Foucault. Der Faden ist gerissen. Berlin: Merve, 1977, S. 21-58.

Fradin, Dennis B. und Judith Bloom Fradin. Ida B. Wells: Mother of the Civil Rights Movement. New York: Clarion Books, 2000.

Frank, Andrew und Mark C. Carnes. The Routledge Historical Atlas of the American South. New York: Routledge, 1999.

Frankel, Oz. „Whatever Happened to ,Red Emma‘? Emma Goldman, from Alien Rebel to American Icon.“ The Journal of American History 83, no. 3 (1996):903-942.

Franklin, John Hope und Foner, Eric Foner. Reconstruction after the Civil War. Chicago, IL, London: University of Chicago Press, 2013.

Fraser, James W. A History of Hope: When Americans Have Dared to Dream of a Better Future. New York: Palgrave Macmillan, 2002.

Fraser, Matthew. Weapons of Mass Destraction: Soft Power and the American Empire. Toronto, ON: Key Porter Books, 2003.

Frazier, Ian. Great Plains. New York: Picador USA, 2001.

Fredman, Lionel E. The Australian Ballot: The Story of an American Reform. East Lansing, MI: Michigan State University Press, 1968. 
Fredrickson, George M. „A Man but Not a Brother: Abraham Lincoln and Racial Equality.“ The Journal of Southern History 41, no. 1 (1975):39-58.

Freeberg, Ernest. Democracy's Prisoner: Eugene V. Debs, the Great War, and the Right to Dissent. Cambridge, MA: Harvard University Press, 2008.

Freedman, Jonathan. The Temple of Culture: Assimilation and Anti-Semitism in Literary Anglo-America. New York: Oxford University Press, 2000.

Freedman, Russell. Kids at Work: Lewis Hine and the Crusade against Child Labor. New York: Clarion Books, 1994.

Freidel, Frank Burt und Pollack, Norman. Builders of American Institutions: Readings in United States History. Chicago, IL: Rand McNally, 1963.

Fremon, David K. The Alaska Purchase in American History. Berkeley Heights, NJ: Enslow Publishers, 1999.

Fried, Barbara. The Progressive Assault on Laissez Faire: Robert Hale and the First Law and Economics Movement. Cambridge, MA: Harvard University Press, 1998.

Friedman, Jonathan und Randeria, Shalini. Worlds on the Move: Globalization, Migration, and Cultural Security. London, New York, New York: I.B. Tauris. Distributed in the United States by Palgrave Macmillan, 2004.

Friedman, Milton. „Bimetallism Revisited.“ The Journal of Economic Perspectives 4, no. 4 (1990):85-104.

Friedman, Milton. „The Crime of 1873.“ Journal of Political Economy 98, no. 6 (1990):1159-1194.

Friedman, Milton und Schwartz, Anna J. A Monetary History of the United States, 1867-1960. Princeton, NJ: Princeton University Press, 1963.

Froehlich, Fritz E. und Allen Kent. The Froehlich/Kent Encyclopedia of Telecommunications. New York: M. Dekker, 1991.

Frost, Robert. The Road Not Taken: And Other Poems. New York: Dover Publications, 1993.

Fry, C. George und Kurz, Joel R.. Washington Gladden as a Preacher of the Social Gospel, 1882 -1918. Lewiston, NY: E. Mellen Press, 2003.

Fry, Joseph A. „From Open Door to World Systems: Economic Interpretations of Late Nineteenth Century American Foreign Relations.“ Pacific Historical Review 1996, 65 (2):277- 303.

Fuchs, Lawrence H. The American Kaleidoscope: Race, Ethnicity, and the Civic Culture. Hanover, NH: Wesleyan University Press, 1990.

Fuller, Robert H. Jubilee Jim from Circus Traveler to Wall Street Rogue: The Remarkable Life of Colonel James Fisk, Jr. New York: Texere, 2001.

Fulton, Robert A. Honor for the Flag: The Battle of Bud Dajo - 1906 and the Moro Massacre. Bend, OR: Tumalo Creek Press, 2011.

Fulton, Robert A. Moroland, 1899-1906 America's First Attempt to Transform an Islamic Society. Bend, OR: Tumalo Creek Press, 2007.

Gabriel, Mary. Notorious Victoria: The Life of Victoria Woodhull, Uncensored. Chapel Hill, N.C: Algonquin Books of Chapel Hill, 1998.

Gaido, Daniel. The Formative Period of American Capitalism: A Materialist Interpretation. New York: Routledge, 2006.

Gaither, Gerald H. Blacks and the Populist Movement: Ballots and Bigotry in the New South. Tuscaloosa, AL: University of Alabama Press, 2005.

Galambos, Louis. „Theodore N. Vail and the Role of Innovation in the Modern Bell System.“ The Business History Review 66, no. 1 (1992):95-126. 
Gallego Palomares, José Ángel. Ferrocarril y Transición al Capitalismo en la Mancha, 1850-1936. Ciudad Real: Almud, Ediciones de Castilla-La Mancha, 2009.

Gao, Chunchang. African Americans in the Reconstruction Era. New York: Garland Pub, 2000.

Garbade, Kenneth D. Birth of a Market: The U.S. Treasury Securities Market from the Great War to the Great Depression. Cambridge, MA: MIT Press, 2012.

Garcia, Guadalupe. „Urban Guajiros: Colonial Reconcentración, Rural Displacement and Criminalisation in Western Cuba, 1895-1902.“ Journal of Latin American Studies 43, no. 2 (2011):209-235.

Garcia, Neftali G. The Mexican Revolution: Legacy of Courage. Bloomington, IN: Xlibris Corporation, 2010.

Garcia, Matt. A World of Its Own: Race, Labor, and Citrus in the Making of Greater Los Angeles, 1900-1970. Chapel Hill, NC: University of North Carolina Press, 2001.

Garner, John S. The Company Town: Architecture and Society in the Early Industrial Age. New York: Oxford University Press, 1992.

Garner, John S. The Model Company Town: Urban Design through Private Enterprise in Nineteenth-Century New England. Amherst, MA: University of Massachusetts Press, 1984.

Garner, Steve. Whiteness: An Introduction. Milton Park, Abingdon, Oxon, New York: Routledge, 2007.

Garraty, John A. Right-Hand Man: The Life of George W. Perkins. Westport, CT: Greenwood Press, 1978.

Garrett, Martin A. und Xu, Zhenhui. „The Efficiency of Sharecropping: Evidence from the Postbellum South.“ Southern Economic Journal 69, no. 3 (2003):578-595.

Garrison, Tim Alan. The Legal Ideology of Removal: The Southern Judiciary and the Sovereignty of Native American Nations. Athens, GA: University of Georgia Press, 2002.

Garrouste, Pierre und loannides, Stavros. Evolution and Path Dependence in Economic Ideas: Past and Present. Cheltenham, Northampton, MA: Edward Elgar, 2001.

Gartner, John D. The Hypomanic Edge: The Link between a Little Craziness and a Lot of Success in America. New York: Simon \& Schuster, 2005.

Garud, Raghu und Karnøe, Peter. Path Dependence and Creation. Mahwah, NJ: Lawrence Erlbaum Associates, 2001.

Gates, Paul W. „History and Appraisal of U. S. Land Policy 1862-1935.“ Agricultural History 36, no. 4 (1962):224.

Gates, Paul W. „Land Policy and Its Relation to Agricultural Production and Distribution, 1862 to 1933: Discussion.“ The Journal of Economic History 22, no. 4 (1962):473- 476.

Gates, Paul W. Free Homesteads for All Americans: The Homestead Act of 1862. Washington, DC: Civil War Centennial Commission, 1962.

Gates, Paul W. „Land Policy and Tenancy in the Prairie Counties of Indiana.“ Indiana Magazine of History 35, no. 1 (1939):1-26.

Gedacht, Joshua. „,Mohammedan Religion Made It Necessary to Fire': Massacres on the U.S. Imperial Frontier, from South Dakota to the Southern Philippines.“ In: Alfred W. McCoy und Francisco A. Scarano .The Colonial Crucible: Empire in the Making of the Modern American State.Madison, WI: University of Wisconsin Press, 2009, S. 397-409.

Geiger, Rudolf. Der deutsche Amerikaner: Carl Schurz. Vom deutschen Revolutionär zum amerikanischen Staatsmann. Gernsbach: Katz, 2007.

Geist, Valerius. Buffalo Nation: History and Legend of the North American Bison. Stillwater, MN: Voyageur Press, 1996. 
Geisst, Charles R. Monopolies in America: Empire Builders and Their Enemies from Jay Gould to Bill Gates. Oxford, New York: Oxford University Press, 2000.

Geisst, Charles R. Wall Street: A History from Its Beginnings to the Fall of Enron. Oxford, New York: Oxford University Press, 2004.

Gengarelly, W. Anthony. Distinguished Dissenters and Opposition to the 1919-1920 Red Scare. Lewiston, NY: E. Mellen Press, 1996.

Genthe, Arnold und Tchen, John Kuo Wei. Genthe’s Photographs of San Francisco's Old Chinatown. New York: Dover Publications, 1984.

George, Alexander L, und Juliette L George. Woodrow Wilson and Colonel House: a Personality Study. New York: Dover Publications, 1964.

George, Charles. Life under the Jim Crow Laws. San Diego: Lucent Books, 2000.

Gerber, David A. Anti-Semitism in American History. Urbana, IL: University of Illinois Press, 1986.

Gerteis, Joseph. Class and the Color Line: Interracial Class Coalition in the Knights of Labor and the Populist Movement. Durham, NC: Duke University Press, 2007.

Gilderhus, Mark T. Pan American Visions: Woodrow Wilson in the Western Hemisphere, 1913-1921. Tucson, AZ: University of Arizona Press, 1986.

Gillette, William. Retreat from Reconstruction, 1869-1879. Baton Rouge: Louisiana State University Press, 1979.

Gilligan, Thomas W., Marshall, William J. und Weingast, Barry R.. „Regulation and the Theory of Legislative Choice: The Interstate Commerce Act of 1887.“ Journal of Law and Economics 32, no. 1 (1989):35-61.

Gilmore, Kim. „Slavery and Prison: Understanding the Connections.“ Social Justice 27, no. 3 (81) (2000):195- 205.

Ginger, Ray. The Age of Excess: The United States from 1877 to 1914. New York: Macmillan, 1975.

Gingrich, Newt und Haley, Vince. A Nation Like No Other: Why American Exceptionalism Matters. Washington, DC, New York: Regnery Pub. Distributed to the trade by Perseus Distribution, 2011.

Gjerde, Jon. Major Problems in American Immigration and Ethnic History: Documents and Essays. Boston, MA: Houghton Mifflin, 1998.

Glasner, David und Cooley, Thomas F. (Hg.). Business Cycles and Depressions: An Encyclopedia. New York: Garland Pub, 1997.

Glasson, William Henry und Kinley, Kinley. Federal Military Pensions in the United States. New York etc.: Oxford University Press, American Branch, 1918.

Glickman, Lawrence B. Buying Power: A History of Consumer Activism in America. Chicago, IL, London: University of Chicago Press, 2009.

Go, Julian. Patterns of Empire: The British and American Empires, 1688 to the Present. New York: Cambridge University Press, 2011.

Gold, Charles H. „Hatching Ruin,“ or, Mark Twain's Road to Bankruptcy. Columbia, MO: University of Missouri Press, 2003.

Goldberg, Michael L. „Non-Partisan and All-Partisan: Rethinking Woman Suffrage and Party Politics in Gilded Age Kansas.“ The Western Historical Quarterly 25, no. 1 (1994):21-44.

Goldenberg, Barry M. The Unknown Architects of Civil Rights Thaddeus Stevens, Ulysses S. Grant, and Charles Sumner. Los Angeles, CA: Critical Minds Press, 2011.

Goldman, Emma. My Disillusionment in Russia. London: C. W. Daniel Company, 1925. 
Goldstein, Carolyn M. Creating Consumers: Home Economists in Twentieth-Century America. Chapel Hill, NC: University of North Carolina Press, 2012.

Goldstein, Eric L. The Price of Whiteness: Jews, Race, and American Identity. Princeton, NJ: Princeton University Press, 2006.

Goldstein, Judith. Ideas, Interests, and American Trade Policy. Ithaca: Cornell University Press, 1993.

Goldstein, Judith. The Politics of Ethnic Pressure the American Jewish Committee Fight Against Immigration Restriction, 1906 -1917. New York: Garland Pub, 1990.

Goldstein, Warren Jay. Playing for Keeps: A History of Early Baseball. Ithaca, NY: Cornell University Press, 1989.

Goldstone, Jack A. „Initial Conditions, General Laws, Path Dependence, and Explanation in Historical Sociology.“ American Journal of Sociology. 1998, 104 (3):829-845.

Golway, Terry. Machine Made: Tammany Hall and the Creation of Modern American Politics. New York: W.W. Norton \& Company, 2014.

Gómez, Laura E. Manifest Destinies: The Making of the Mexican American Race. New York: New York University, 2007.

Goodin, Robert E. und Tilly, Charles. The Oxford Handbook of Contextual Political Analysis. Oxford: New York: Oxford University Press, 2006.

Goodstein, Eban. „The Economic Roots of Environmental Decline: Property Rights or Path Dependence?“ Journal of Economic Issues. 1995, 29 (4):1029-1043.

Goodwin, Jason. Otis: Giving Rise to the Modern City. Chicago, IL: Ivan R. Dee, 2001.

Goodwyn, Lawrence. Democratic Promise: The Populist Moment in America. New York: Oxford University Press, 1976.

Goodwyn, Lawrence. The Populist Moment: A Short History of the Agrarian Revolt in America. New York: Oxford University Press, 1978.

Gordon, John Steele. An Empire of Wealth: The Epic History of American Economic Power. New York: HarperCollins, 2004.

Gordon, John Steele. The Scarlet Woman of Wall Street: Jay Gould, Jim Fisk, Cornelius Vanderbilt, the Erie Railway Wars, and the Birth of Wall Street. New York: Weidenfeld \& Nicolson, 1988.

Gould, James W. „American Imperialism in Southeast Asia before 1898.“ Journal of Southeast Asian Studies. 1972, 3 (2):306-314.

Gould, Lewis L. The Presidency of William McKinley. Lawrence, KS: Regents Press of Kansas, 1980.

Gould, Stephen Jay. The Mismeasure of Man. New York: Norton, 2006.

Gowan, Peter. „Empire as Superstructure.“ Security Dialogue. 2004, 35 (2):258-261.

Graff, Henry F. Grover Cleveland. New York: Times Books, 2002.

Graham, W. A. The Story of the Little Big Horn: Custer's Last Fight. Mechanicsburg, PA: Stackpole Books, 1994.

Grandy, Christopher. „Original Intent and the Sherman Antitrust Act: A Re-Examination of the Consumer-Welfare Hypothesis.“ The Journal of Economic History 53, no. 2 (1993):359-376.

Grant, H. Roger. „Follow the Flag“: A History of the Wabash Railroad Company. DeKalb, IL: Northern Illinois University Press, 2004.

Graves, Joseph L. The Emperor's New Clothes: Biological Theories of Race at the Millennium. New Brunswick, N): Rutgers University Press, 2001. 
Grayson, Lawrence P. The Making of an Engineer: An Illustrated History of Engineering

Education in the United States and Canada. New York: Wiley, 1993.

Grebing, Helga, von der Brelie-Lewien, Doris und Franzen Hans-Joachim. Der „Deutsche

Sonderweg“ in Europa 1806-1945: Eine Kritik. Stuttgart: W. Kohlhammer, 1986.

Green, Fletcher M. „Origins of the Credit Mobilier of America.“ The Mississippi Valley Historical Review 46, no. 2 (1959):238-251.

Green, Hardy. The Company Town: The Industrial Edens and Satanic Mills That Shaped the American Economy. New York: Basic Books, 2010.

Green, James R. Death in the Haymarket: A Story of Chicago, the First Labor Movement, and the Bombing That Divided Gilded Age America. New York: Pantheon Books, 2006.

Greenberg, Kenneth S. Honor \& Slavery Lies, Duels, Noses, Masks, Dressing as a Woman, Gifts, Strangers, Humanitarianism, Death, Slave Rebellions, the Proslavery Argument, Baseball, Hunting, and Gambling in the Old South. Princeton, NJ: Princeton University Press, 1996.

Greene, Julie. Pure and Simple Politics: The American Federation of Labor and Political Activism, 1881-1917. Cambridge, New York, Cambridge University Press, 1998.

Greenwald, Emily. Reconfiguring the Reservation: The Nez Perces, Jicarilla Apaches, and the Dawes Act. Albuquerque, NM: University of New Mexico Press, 2002.

Greenwood, Janette Thomas. Bittersweet Legacy: The Black and White „Better Classes“ in Charlotte, 1850-1910. Chapel Hill, NC: University of North Carolina Press, 1994.

Grenville, J. A. S und Young, George Berkeley. Politics, Strategy, and American Diplomacy: Studies in Foreign Policy, 1873-1917. New Haven, CT: Yale University Press, 1966.

Griffis, William Elliot. Townsend Harris: First American Envoy in Japan. Freeport, NY: Books for Libraries Press, 1971.

Grippo, Robert M. Macy's: The Store, the Star, the Story. Garden City Park, NY: Square One Publishers, 2009.

Griswold, Robert L. Family and Divorce in California, 1850-1890: Victorian Illusions and Everyday Realities. Albany, NY: State University of New York Press, 1982.

Griswold, Wesley S. A Work of Giants: Building the First Transcontinental Railroad. New York: McGraw-Hill, 1962.

Grodinsky, Julius. Jay Gould: His Business Career, 1867-1892. New York: Arno Press, 1981.

Grodinsky, Julius. Transcontinental Railway Strategy, 1869-1893: A Study of Businessmen. Philadelphia, PA: University of Pennsylvania Press, 1962.

Grossman, Mark. Political Corruption in America: An Encyclopedia of Scandals, Power, and Greed. Millerton, NY: Grey House Pub, 2008.

Grützmann, Imgart, Dreher, Martin Norberto und Feldens, Jorge Augusto. Imigração Alemã No Rio Grande do Sul Recortes. São Leopoldo, RS: Okos Editora. UNISINOS, 2008.

Guha, Ranajit. Dominance without Hegemony: History and Power in Colonial India. Cambridge, MA: Harvard University Press, 1997.

Guha, Ranajit. Elementary Aspects of Peasant Insurgency in Colonial India. Durham, NC: Duke University Press, 1999.

Guha, Ranajit. Subaltern Studies: Writings on South Asian History and Society. Delhi, New York: Oxford University Press, 1982.

Gurock, Jeffrey S. Anti-Semitism in America. New York: Routledge, 1998.

Gurock, Jeffrey S. East European Jews in America, 1880-1920: Immigration and Adaptation. New York: Routledge, 1998. 
Gustafson, Melanie S. Women and the Republican Party, 1854-1924. Urbana, IL: University of Illinois Press, 2001

Gutman, Herbert George. The Black Family in Slavery and Freedom, 1750-1925. New York: Pantheon Books, 1976.

Gutmann, Myron P., Pullum-Pinon, Sara M., Witkowski, Kristine, Deane, Glenn D., und Merchant, Emily. „Land Use and Familiy Formation in the Settlement of the US Great Plains." Social Science History 36, no. 3 (2012):279-310.

Gyory, Andrew. Closing the Gate: Race, Politics, and the Chinese Exclusion Act. Chapel Hill, NC: University of North Carolina Press, 1998.

Hackemer, Kurt. The U.S. Navy and the Origins of the Military-Industrial Complex, 1847-1883. Annapolis, MD: Naval Institute Press, 2001.

Hagedorn, Hermann. The Roosevelt Family of Sagamore Hill. New York: Macmillan, 1954.

Hahn, Hans-Werner. Die industrielle Revolution in Deutschland. München: Oldenbourg Verlag, 2005.

Hajo, Cathy Moran. Birth Control on Main Street: Organizing Clinics in the United States, 1916 -1939. Urbana, IL: University of Illinois Press, 2010.

Hall, John, Dominguez Lacasa, Iciar und Günther, Jutta. „Path Dependence and QWERTY's Lock-In: Toward a Veblenian Interpretation.“ Journal of Economic Issues 45, no. 2 (2011): 457-64.

Hall, Linda B. und Coerver, Don M.. Revolution on the Border the United States and Mexico, 1910-1920. Albuquerque: University of New Mexico Press, 1988.

Hall, Linda B. und Coerver, Don M.. „Woodrow Wilson, Public Opinion, and the Punitive Expedition: A Re-Assessment.“ New Mewico Historical Review 72 (1997):171-194.

Hall, Peter A. und Taylor, Rosemary C. R. „La Science Politique et les Trois Néo-Institutionalismes." Revue Française de Science Politique. 1997, 47 (3/4):469- 496.

Hall, Robert und Lieberman, Marc. Microeconomics: Principles and Applications. Cengage Learning, 2009.

Halpern, Monica und Ann Rossi. Moving North: African Americans and the Great Migration, 1915-1930. Washington, DC: National Geographic, 2006.

Hämäläinen, Pekka. The Comanche Empire. New Haven, CT: Yale University Press, 2008.

Hamilton, Daniel W. The Limits of Sovereignty: Property Confiscation in the Union and the Confederacy during the Civil War. Chicago, IL: University of Chicago Press, 2007.

Hamilton, Richard F. President McKinley, War and Empire. New Brunswick, NJ: Transaction Publishers, 2006-2007.

Hammond, Virgie Lee. 500 Rebels with a Cause: Coxey's Army Bound for Washington, DC. Quincy, IL: Mid-West Press, 1989.

Hampf, M. Michaela und Simone Müller-Pohl. Global Communication Electric: Business, News and Politics in the World of Telegraphy. Frankfurt/Main: Campus, 2013.

Hanna, Alfred Jackson und Kathryn Abbey Hanna. Napoleon III and Mexico: American Triumph over Monarchy. Chapel Hill, NC: University of North Carolina Press, 1971.

Hanna, Kathryn Abbey. „The Roles of the South in the French Intervention in Mexico.“ The Journal of Southern History. 1954, 20 (1):3-21.

Hannigan, Robert E. The New World Power: American Foreign Policy, 1898-1917. Philadelphia, PA: University of Pennsylvania Press, 2002. 
Hansen, Bradley A. und Hansen, Mary Eschelbach. „The Role of Path Dependence in the Development of US Bankruptcy Law, 1880-1938.“ Journal of Institutional Economics. 2007, 3 (2):203-225.

Hansen, Stephen L. The Making of the Third Party System: Voters and Parties in Illinois, 1850 -1876. Ann Arbor, MI: UMI Research Press, 1980.

Hapke, Laura. Sweatshop: The History of an American Idea. New Brunswick, NJ: Rutgers University Press, 2004.

Dies Tales of the Working Girl: Wage-Earning Women in American Literature, 1890-1925. New York, Toronto, New York: Twayne Publishers, 1992.

Harbaugh, William Henry. Lawyer's Lawyer, the Life of John W. Davis. New York: Oxford University Press, 1973.

Harbaugh, William Henry. Power and Responsibility: The Life and Times of Theodore Roosevelt. New York: Farrar, Straus and Cudahy, 1961.

Hardt, Michael und Negri, Antonio. Empire. Cambridge, MA: Harvard University Press, 2000.

Hareven, Tamara K. und Randolph Langenbach. Amoskeag: Life and Work in an American Factory-City. Hanover, NH: University Press of New England, 1995.

Hargadon, Andrew B. und Yellowlees Douglas. „When Innovations Meet Institutions: Edison and the Design of the Electric Light." Administrative Science Quarterly 46, no. 3 (2001):476-501.

Harris, William Hamilton. The Harder We Run: Black Workers Since the Civil War. New York: Oxford University Press, 1982.

Harvey, David. The New Imperialism. Oxford, New York: Oxford University Press, 2005.

Harvey, Frank P. Explaining the Iraq War: Counterfactual Theory, Logic and Evidence.

Cambridge, New York: Cambridge University Press, 2012.

Harvey, George Brinton McClellan. Henry Clay Frick: The Man. Washington, DC: Beard Books, 2002.

Haskins, James, Kathleen Benson und Virginia Schomp. The Rise of Jim Crow. Tarrytown, NY: Marshall Cavendish Benchmark, 2008.

Hata, Donald Teruo. „Undesirables“: Early Immigrants and the Anti-Japanese Movement in San Francisco, 1892-1893. Prelude to Exclusion. New York: Arno Press, 1978.

Haupt, Claudia E. Religion-State Relations in the United States and Germany the Quest for Neutrality. Cambridge, New York: Cambridge University Press, 2012.

Havemeyer, Harry W. Henry Osborne Havemeyer: The Most Independent Mind. New York: H.W. Havemeyer, 2010.

Haverty-Stacke, Donna T. America's Forgotten Holiday: May Day and Nationalism, 1867-1960. New York: New York University Press, 2009.

Hawkins, Mike. Social Darwinism in European and American Thought, 1860-1945: Nature as Model and Nature as Threat. Cambridge, New York: Cambridge University Press, 1997.

Haynes, Frederick Emory. James Baird Weaver. New York: Arno Press, 1975.

Heale, M. J. American Anticommunism: Combating the Enemy Within, 1830-1970. Baltimore, MD: Johns Hopkins University Press, 1990.

Healy, David. James G. Blaine and Latin America. Columbia, MO: University of Missouri Press, 2001.

Healy, David. US Expansionism: The Imperialist Urge in the 1890s. Madison, WI: University of Wisconsin Press, 1970.

Hedlund, Stefan. Russian Path Dependence. London, New York: Routledge, 2005. 
Heggen, Alfred. Erfindungsschutz und Industrialisierung in Preußen 1793-1877. Göttingen:

Vandenhoeck und Ruprecht, 1975.

Heidegger, Martin. Sein und Zeit. Tübingen: Niemeyer, 1986.

Heinrich, Torsten. Technological Change and Network Effects in Growth Regimes: Exploring the Microfoundations of Economic Growth. New York: Routledge, 2013.

Hellmann, Gunther, Vagner, Wolfgang und Baumann, Baumann. Deutsche Außenpolitik: Eine Einführung. Wiesbaden: Springer, 2014.

Henderson, Thomas. „The Western Federation of Miners: The Course of Western Radical Unionism, 1903-1907.“ Dissertation University of Virginia, 1968.

Henderson, Wayne und Scott Benjamin. Standard Oil: The First 125 Years. Osceola, WI, USA: Motorbooks International, 1996.

Hendricks, Gordon. Albert Bierstadt: Painter of the American West. New York: Harrison House, 1988.

Henig, Gerald S. Henry Winter Davis: Antebellum and Civil War Congressman from Maryland. New York: Twayne Publishers, 1973.

Henige, David P. Numbers from Nowhere: The American Indian Contact Population Debate. Norman, OK: University of Oklahoma Press, 1998.

Henry, Robert S. „The Railroad Land Grant Legend in American History Texts.“ Mississippi Valley Historical Review 32, no. 2 (1945):171-194.

Herfel, William E. „Positive Feedback and Praxiology: Path Dependence in Action.“ In: Gasparski, Wojciech und Airaksinen, Timo (Hg.). Praxiology and the Philosophy of Technology. New Brunswick, NJ: Transaction Publishers, 2008, S. 55-80.

Hernández, Telesforo-Marcial. Ferrocarriles y Capitalismo en el País Valenciano, 1843-1879. Valencia: Excmo. Ayuntamiento de Valencia, Delegación Municipal de Cultura, 1983.

Herrin, Dean A. America Transformed: Engineering and Technology in the Nineteenth Century. Reston, VA: American Society of Civil Engineers, 2002.

Hersey, Mark D. My Work Is That of Conservation: An Environmental Biography of George Washington Carver. Athens, GA: University of Georgia Press, 2011.

Hessen, Robert. Steel Titan: The Life of Charles M. Schwab. Pittsburgh, PA: University of Pittsburgh Press, 1990.

Hewitt, Ben. The Town That Food Saved: How One Community Found Vitality in Local Food. Emmaus, PA: Rodale, 2011.

Hicks, John Donald. Populist Revolt: A History of the Farmers' Alliance and the People's Party. Minneapolis, MN: University of Minnesota Press, 2009.

Hidy, Ralph Willard. The Great Northern Railway: A History. Boston, MA: Harvard Business School Press, 1988.

Hietala, Thomas R. Manifest Design American Exceptionalism and Empire. Ithaca, NY: Cornell University Press, 2003.

Higginbotham, A. Leon. Shades of Freedom: Racial Politics and Presumptions of the American Legal Process. New York: Oxford University Press, 1996.

Higgs, Robert. Competition and Coercion: Blacks in the American Economy, 1865-1914. Chicago, IL: University of Chicago Press, 1980.

Higham, John. Send These to Me Immigrants in Urban America. Baltimore: Johns Hopkins University Press, 1984.

Higham, John. Strangers in the Land: Patterns of American Nativism, 1860-1925. New Brunswick, NJ: Rutgers University Press, 2002. 
Hild, Matthew. Greenbackers, Knights of Labor, and Populists: Farmer-Labor Insurgency in the Late-Nineteenth-Century South. Athens, GA: University of Georgia Press, 2007.

Hilferding, Rudolf. Das Finanzkapital: Eine Studie zur jüngsten Entwicklung des Kapitalismus. Wien: Ignaz Brand \& Co., 1910.

Hillstrom, Kevin. The Dream of America Immigration, 1870-1920. Detroit, MI: Omnigraphics, 2009.

Hillstrom, Laurie Collier. The Muckrakers and the Progressive Era. Detroit, MI: Omnigraphics, 2010.

Hindman, Hugh D. Child Labor: An American History. Armonk, NY: M. E. Sharpe, 2002.

Hine, Robert V. und John Mack Faragher. Frontiers: A Short History of the American West. New Haven, CT: Yale University Press, 2007.

Hira Singh. The Asiatic Mode of Production: A Critical Analysis. Toronto: Dept. of Sociology, University of Toronto, 1983.

Hirsch, Susan E. After the Strike: A Century of Labor Struggle at Pullman. Urbana, IL: University of Illinois Press, 2003.

Hirschbein, Ron. Voting Rites: The Devolution of American Politics. Westport, CT: Praeger, 1999.

Hoch, Bradley R. Thaddeus Stevens in Gettysburg: The Making of an Abolitionist. Gettysburg, PA: Adams County Historical Society, 2005.

Hodgson, Godfrey. The Myth of American Exceptionalism. New Haven: Yale University Press, 2009.

Hoerder, Dirk. American Labor and Immigration History, 1877-1920s: Recent European Research. Urbana, IL: University of Illinois Press, 1983.

Hoerder, Dirk und Faires, Nora Helen. Migrants and Migration in Modern North America Cross-Border Lives, Labor Markets, and Politics. Durham, NC: Duke University Press, 2011.

Hoffer, Williamjames. Plessy v. Ferguson: Race and Inequality in Jim Crow America. Lawrence, Kan: University Press of Kansas, 2012.

Hoffmann, Donald. The Architecture of John Wellborn Root. Chicago, IL: University of Chicago Press, 1988.

Hofstadter, Richard. The Age of Reform: From Bryan to F. D. R. New York: Vintage Books, 1955. Hofstadter, Richard. Anti-Intellectualism in American Life. New York: Knopf, 1963.

Hofstadter, Richard. The Paranoid Style in American Politics, and Other Essays. New York: Vintage Books, 2008.

Hoganson, Kristin L. Consumers' Imperium: The Global Production of American Domesticity, 1865-1920. Chapel Hill, NC: University of North Carolina Press, 2007.

Hoganson, Kristin L. Fighting for American Manhood: How Gender Politics Provoked the Spanish-American and Philippine-American Wars. New Haven, CT: Yale University Press, 1998.

Hogarty, Richard A. Leon Abbett's New Jersey: The Emergence of the Modern Governor. Philadelphia: American Philosophical Society, 2001.

Hoge, Cecil C. The First Hundred Years Are the Toughest: What We Can Learn from the Century of Competition Between Sears and Wards. Berkeley, CA: Ten Speed Press, 1988.

Holberton, William B. Demobilization of the Union Army 1865-1866. MA-Thesis, Lehigh University, 1993.

Holberton, William B. Homeward Bound: The Demobilization of the Union and Confederate Armies, 1865-1866. Mechanicsburg, PA: Stackpole Books, 2001. 
Hollandsworth, James G. An Absolute Massacre: The New Orleans Race Riot of July 30, 1866. Baton Rouge, LA: Louisiana State University Press, 2001.

Holli, Melvin G. The American Mayor: The Best \& the Worst Big-City Leaders. University Park, PA: Pennsylvania State University Press, 1999.

Holli, Melvin G. Reform in Detroit: Hazen S. Pingree and Urban Politics. Westport, CT: Greenwood Press, 1981.

Hollinshead, Byron. Sourcebook and Index: Documents That Shaped the American Nation. New York: Oxford University Press, 2003.

Holmes, Jack D. L. „The Underlying Causes of the Memphis Race Riot of 1866.“ Tennessee Historical Quarterly. 1958, 17 (3):195-221.

Holt, Michael F. By One Vote: The Disputed Presidential Election of 1876. Lawrence, KS: University Press of Kansas, 2008.

Holt, Marilyn Irvin. Linoleum, Better Babies, \& the Modern Farm Woman, 1890-1930. Lincoln, London: University of Nebraska Press, 1995.

Homberger, Eric. Mrs. Astor's New York: Money and Social Power in a Gilded Age. New Haven, CT: Yale University Press, 2002.

Hopkins, June. Harry Hopkins: Sudden Hero, Brash Reformer. New York: St. Martin's Press, 1999.

Horn, Steven Edward. „Property and Democracy: Authority in Four American Property-Rights Regimes.“ Dissertation, University of Southern California, 2008.

Horowitz, Irving Louis. The Anarchists. New Brunswick, NJ: Aldine Transaction, 2005.

Horton, James Oliver. „Social History and the African American Experience.“ In: Beth L. Savage und Carol D. Shull (Hg.). African American Historic Places. Washington, DC: Preservation Press, 1994, S. $15-24$.

Horst, Ulrich. „Ergodicity and Non-Ergodicity in Economics“, Working Paper. http://horst.qflberlin.de/sites/files/u2/Palgrave.pdf. Gesehen am 1.4. 2017. Seit 2018 unter anderer URL: https://www.applied-financial-mathematics.de/sites/default/files/Palgrave.pdf. Gesehen 12.5.2018.

Hosen, Frederick E. Federal Laws of the Reconstruction: Principal Congressional Acts and Resolutions, Presidential Proclamations, Speeches and Orders, and Other Legislative and Military Documents, 1862-1875. Jefferson, NC: McFarland \& Co, 2010.

Houghton, Gillian. Ellis Island: A Primary Source History of an Immigrant's Arrival in America. New York: Rosen Pub. Group, 2004.

House, Albert V. „Republicans and Democrats Search for New Identities, 1870-1890.“ The Review of Politics 31, no. 4 (1969):466- 476.

Hovenkamp, Herbert. „Regulatory Conflict in the Gilded Age: Federalism and the Railroad Problem.“ The Yale Law Journal 97, no. 6 (1988):1017-1072.

Howard, Ernest. Wall Street Fifty Years After Erie: Being a Comparative Account of the Making and Breaking of the Jay Gould Railroad Fortune. Boston, MA: The Stratford Company, 1923.

Howard, Victor B. Religion and the Radical Republican Movement, 1860-1870. Lexington, KY: University Press of Kentucky, 1990.

Howbert, Irving. The Indians of the Pike's Peak Region Including an Account of the Battle of Sand Creek, and of Occurrences in El Paso County, Colorado, during the War with the Cheyennes and Arapahoes, in 1864 and 1868. New York: The Knickerbocker Press, 1914. 
Howe, George F. Chester A. Arthur: A Quarter-Century of Machine Politics. Norwalk, CT: Easton Press, 1987.

Hower, Ralph M. History of Macy's of New York, 1858-1919: Chapters in the Evolution of the Department Store. Cambridge, MA: Harvard University Press, 1943.

Howse, Jennifer. Reconstruction. New York: Weigl Publishers, 2008.

Hudson, David L. The Fourteenth Amendment: Equal Protection under the Law. Berkeley Heights, NJ: Enslow Publishers, 2002.

Hudson, Linda S. Mistress of Manifest Destiny: A Biography of Jane McManus Storm Cazneau, 1807-1878. Austin: Texas State Historical Association, 2001.

Hughes, Thomas Parke. American Genesis: A Century of Invention and Technological Enthusiasm, 1870-1970. New York: Viking, 1989.

Huhnholz, Sebastian. Krisenimperialität: Romreferenz im US-amerikanischen Empire-Diskurs. Frankfurt/Main: Campus, 2014.

Hume, Richard L. und Jerry B. Gough. Blacks, Carpetbaggers, and Scalawags: The Constitutional Conventions of Radical Reconstruction. Baton Rouge, LA: Louisiana State University Press, 2008.

Hummel, Jeffrey Rogers. Emancipating Slaves, Enslaving Free Men: A History of the American Civil War. Chicago, IL: Open Court, 1996.

Hunt, James L. Marion Butler and American Populism. Chapel Hill, NC: University of North Carolina Press, 2003.

Hunt, Michael H. Ideology and U.S. Foreign Policy. New Haven, CT: Yale University Press, 2009. Hurley, Vic. Swish of the Kris: The Story of the Moros. New York: E.P.Dutton \& Co., Inc., 1936. Hutcheon, Linda. The Politics of Postmodernism. London, New York: Routledge, 2003. Husband, Julie und Jim O'Loughlin. Daily Life in the Industrial United States, 1870-1900. Westport, CT: Greenwood Press, 2004.

Icenoggle, Jodi. Schenck v. United States and the Freedom of Speech Debate: Debating Supreme Court Decisions. Berkeley Heights, NJ: Enslow Publishers, 2005.

Igler, David. Industrial Cowboys: Miller \& Lux and the Transformation of the Far West, 1850 -1920. Berkeley, CA: University of California Press, 2001.

Ignatieff, Michael. Empire Lite: Nation-Building in Bosnia, Kosovo, and Afghanistan. Toronto: Penguin Canada, 2003.

Ignatieff, Michael. The Lesser Evil: Political Ethics in an Age of Terror. Edinburgh: Edinburgh University Press, 2005.

Ignatiev, Noel. How the Irish Became White. New York: Routledge, 2008.

Ikenberry, G. John. The Crisis of American Foreign Policy: Wilsonianism in the Twenty-First Century. Princeton, NJ: Princeton University Press Princeton, 2009.

Ikenberry, G. John und Inoguchi, Takashi. The Uses of Institutions: The U.S., Japan, and Governance in East Asia. New York: Palgrave Macmillan, 2007.

Ikenberry, G. John, Mastanduno, Michael und Wohlforth, William Curti. International Relations: Theory and the Consequences of Unipolarity. Cambridge, New York: Cambridge University Press, 2011.

Ingle, Joseph B. Slouching toward Tyranny: Mass Incarceration, Death Sentences and Racism. New York: Algora, 2015.

Iriye, Akira and Saunier, Pierre-Yves. The Palgrave Dictionary of Transnational History. Basingstoke: Palgrave Macmillan, 2009. 
Irons, Peter H. A People's History of the Supreme Court: The Men and Women Whose Cases and Decisions Have Shaped Our Constitution. New York: Penguin Books, 2006.

Irwin, Douglas A. „Higher Tariffs, Lower Revenues? Analyzing the Fiscal Aspects of ,The Great Tariff Debate of 1888“ “ NBER Working Papers 6239 (1997):1-23.

Israel, Paul. From Machine Shop to Industrial Laboratory: Telegraphy and the Changing Context of American Invention, 1830-1920. Baltimore, MD: Johns Hopkins University Press, 1992.

Iversen, Kristen. Molly Brown: Unraveling the Myth. Boulder, Colo: Johnson Books, 1999. Jackson, Curtis Emanuel und Galli, Marcia J. A History of the Bureau of Indian Affairs and Its Activities among Indians. San Francisco, CA: R \& E Research Associates, 1977.

Jackson, John P. und Weidman, Nadine M.. Race, Racism, and Science Social Impact and Interaction. Santa Barbara, CA: ABC-CLIO, 2004.

Jackson, John P. „The Origins of Scientific Racism.“ The Journal of Blacks in Higher Education. 2005, (50):66-79.

Jackson, Luther P. „The Educational Efforts of the Freedmen's Bureau and Freedmen's Aid Societies in South Carolina, 1862-1872." The Journal of Negro History 8, no. 1 (1923):1- 40.

Jackson, Robert Max. Destined for Equality: The Inevitable Rise of Women's Status. Cambridge, MA: Harvard University Press, 1998.

Jackson, Stanley. J.P. Morgan: A Biography. New York: Stein and Day, 1983.

Jacobson, Matthew Frye. Barbarian Virtues: The United States Encounters Foreign Peoples at Home and Abroad, 1876-1917. New York: Hill and Wang, 2000.

Jäger, Wolfgang und Welz, Wolfgang. Regierungssystem der USA: Lehr- und Handbuch. München, Wien: R. Oldenbourg Verlag, 1995.

Jaher, Frederic Cople. A Scapegoat in the New Wilderness: The Origins and Rise of Anti-Semitism in America. Cambridge, MA: Harvard University Press, 1994.

James, Edward T., Miller Jacoby, Robin, Schrom Dye, Nancy und National Women's Trade Union League of America. Papers of the Women's Trade Union League and Its Principal Leaders: Guide to the Microfilm Edition. Woodbridge, CT: Published for the Schlesinger Library, Radcliffe College by Research Publications, 1981.

James, Henry. Richard Olney and His Public Service with Documents, Including Unpublished Diplomatic Correspondence. New York: Da Capo Press, 1971.

James, Joseph B. The Ratification of the Fourteenth Amendment. Macon, GA: Mercer University Press, 1984.

James, Patrick and Hristoulas, Athanasios. „Domestic Politics and Foreign Policy: Evaluating a Model of Crisis Activity for the United States.“ The Journal of Politics. 1994, 56(2):327-348.

James, Ronald M. The Roar and the Silence: A History of Virginia City and the Comstock Lode. Reno, NV: University of Nevada Press, 1998.

Janeway, Eliot. The Economics of Crisis: War, Politics, and the Dollar. New York: Weybright and Talley, 1968.

Jaron Browne. „Rooted in Slavery: Prison Labor Exploitation.“ Race, Poverty \& the Environment 14, no. 1 (2007):42- 44.

Jaycox, Faith. The Progressive Era. New York: Facts on File, 2005.

Jeffers, H. Paul. Roosevelt the Explorer: Teddy Roosevelt's Amazing Adventures as a Naturalist, Conservationist, and Explorer. Lanham, MD, Summit, PA: Taylor Trade Pub., 2003. 
Jenkins, Wilbert L. Seizing the New Day: African Americans in Post-Civil War Charleston. Bloomington, IN: Indiana University Press, 1998.

Jensen, Derrick. The Culture of Make Believe. New York: Context Books, 2002.

Jensen, Ronald J. The Alaska Purchase and Russian-American Relations. Seattle WA: University of Washington Press, 1975.

Jessen, Jens. „Das Märchen vom Revisionisten.“ Die Zeit 34 (2014).

Johanek, Michael C. und Puckett, John L.. Leonard Covello and the Making of Benjamin Franklin High School: Education as if Citizenship Mattered. Philadelphia, PA: Temple University Press, 2007.

Johanningsmeier, Edward P. Forging American Communism the Life of William Z. Foster. Princeton, NJ: Princeton University Press, 1994.

Johnson, Gerald W. The Imperial Republic: Speculation on the Future, if Any, of the Third U.S.A. New York: Liveright, 1972.

Johnson, Ludwell H. „Lincoln and Equal Rights: The Authenticity of the Wadsworth Letter.“ The Journal of Southern History 32, no. 1 (1966):83-87.

Johnson, Ludwell H. „Lincoln's Solution to the Problem of Peace Terms, 1864-1865.“ The Journal of Southern History 34, no. 4 (1968):576-586.

Johnson-Parris, Afi S. „Felon Disenfranchisement: The Unconscionable Social Contract Breached.“ Virginia Law Review 89, no. 1 (2003):109-138.

Johnson, Russell L. „,Great Injustice': Social Status and the Distribution of Military Pensions after the Civil War.“ The Journal of the Gilded Age and Progressive Era 10, no. 2 (2011):137-160.

Joiner, Thekla Ellen. Sin in the City: Chicago and Revivalism, 1880-1920. Columbia, MO: University of Missouri Press, 2007.

Jonas, Manfred. The United States and Germany a Diplomatic History. Ithaca, NY: Cornell University Press, 1984.

Jones, Arthur. Capitalism and Christians: Tough Gospel Challenges in a Troubled World Economy. New York: Paulist Press, 1992.

Jones, Brian Jay. Washington Irving: An American Original. New York: Arcade Publishing, 2011. Jones, Edward L. und Hayes, Floyd W. Forty Acres and a Mule: The Rape of Colored Americans. A Manifesto to the United States Government. Seattle, WA: E.L. Jones, 1994.

Jones, Howard. Crucible of Power: A History of American Foreign Relations to 1913. Lanham, MD: Rowman \& Littlefield Publishers, 2009.

Jones, Jaqueline. „The Political Implications of Black and White Women's Work in the South, 1890-1965.“ In: Louise Tilly und Patricia Gurin (Hg.). Women, Politics, and Change. New York: Russell Sage Foundation, 1990, S. 108-129.

Jones, Jaqueline. The Dispossessed: America's Underclasses from the Civil War to the Present. New York: Basic Books, 1992.

Jordan, David M. Roscoe Conkling of New York: Voice in the Senate. Ithaca NY: Cornell University Press, 1971.

Jordan, Winthrop D. und Leon F. Litwack. The United States. Englewood Cliffs, NJ: Prentice Hall, 1994.

Josephson, Matthew. The Politicos, 1865-1896. New York: Harcourt, Brace and company, 1938.

Josephson, Matthew. The President Makers: The Culture of Politics and Leadership in an Age of Enlightenment, 1896-1919. New York: Harcourt, Brace and Co., 2007. 
Josephson, Matthew. The Robber Barons: The Great American Capitalists, 1861-1901. New Brunswick, NJ: Transaction Publishers, 2011.

Judis, John B. The Folly of Empire: What George W. Bush Could Learn from Theodore Roosevelt and Woodrow Wilson. Oxford, New York: Oxford University Press, 2006.

Jung, Moon-Ho 1969. „Outlawing ,Coolies‘: Race, Nation, and Empire in the Age of Emancipation.“American Quarterly 57, no. 3 (2005).

Kador, John. Charles Schwab: How One Company Beat Wall Street and Reinvented the Brokerage Industry. Hoboken, NJ: J. Wiley, 2002.

Kagan, Robert. „The Benevolent Empire.“ Foreign Policy. 1998, (111):24-35

Kahan, Paul. The Homestead Strike: Labor, Violence, and American Industry. New York: Routledge, 2014.

Kaiser, Ronald W. „The Kondratieff Cycle: Investment Strategy Tool or Fascinating Coincidence?“ Financial Analysts Journal. 1979, 35 (3):57-66.

Kambourian, Elizabeth Cann. The Freedmen's Bureau in Virginia: Names of Destitute Freedmen Dependent upon the Government in the Military Districts of Virginia. Bowie, MD: Heritage Books, 1997.

Kampmark, Binoy. „William Appleman Williams's Tragedy Fifty Years on.“ The Historical Journal 2010, 53 (3):783-794.

Kanellos, Nicolás, Kenya Dworkin y Méndez und Alejandra Balestra. Herencia: The Anthology of Hispanic Literature of the United States. Oxford, New York: Oxford University Press, 2002.

Kann, Bob. Belle and Bob La Follette Partners in Politics. Madison: Wisconsin Historical Society Press, 2008.

Kaplan, Justin. Lincoln Steffens: Portrait of a Great American Journalist. New York: Simon \& Schuster, 2013.

Kaplan, Leslie. Brooklyn Bridge. Barrytown, NY, New York: Station Hill Press, 1992.

Kappler, Charles Joseph Hg. Indian Affairs: Laws and Treaties. Washington, DC: Government Printing Office, 1904.

Karabell, Zachary. Chester Alan Arthur. New York: Times Books, 2004.

Kato, Junko. Regressive Taxation and the Welfare State: Path Dependence and Policy Diffusion. Cambridge, New York: Cambridge University Press, 2003.

Katz, Friedrich. The Life and Times of Pancho Villa. Stanford, CA: Stanford University Press, 1998.

Katzman, David M. Seven Days a Week: Women and Domestic Service in Industrializing America. New York: Oxford University Press, 1978.

Katzman, David M. und William M Tuttle. Plain Folk the Life Stories of Undistinguished Americans. Urbana, IL: University of Illinois Press, 1982.

Kauffman, Stuart A. The Sciences of Complexity and „Origins of Order.“ PSA: Proceedings of the Biennial Meeting of the Philosophy of Science Association. 1990, S. 299-322.

Kauffman, Stuart A. The Origins of Order: Self-Organization and Selection in Evolution. New York: Oxford University Press, 1993.

Kazuko, Furuta. „Inchon Trade: Japanese and Chinese Merchants and the Shanghai Network.“ In: S. Sugiyama und Linda Grove (Hg.). Commercial Networks in Modern Asia. Abingdon: Routledge, 2013, S. 71-95.

Keating, Ann Durkin. Chicagoland: City and Suburbs in the Railroad Age. Chicago, IL: University of Chicago Press, 2005. 
Kehoe, Alice Beck. The Ghost Dance: Ethnohistory and Revitalization. Long Grove, IL: Waveland Press, 2006.

Kehoe, Elisabeth. The Titled Americans: Three American Sisters and the British Aristocratic World into Which They Married. New York: Atlantic Monthly Press, 2004.

Kehr, Eckart und Wehler, Hans Ulrich. Der Primat der Innenpolitik: Gesammelte Aufsätze zur preußisch-deutschen Sozialgeschichte im 19. u. 20. Jahrhundert. Berlin: de Gruyter, 1970.

Keil, Hartmut und Jentz, John B.. German Workers in Chicago: A Documentary History of Working-Class Culture from 1850 to World War I. Urbana, IL: University of Illinois Press, 1988.

Keith, LeeAnna. The Colfax Massacre: The Untold Story of Black Power, White Terror, and the Death of Reconstruction. Oxford, New York: Oxford University Press, 2008.

Kelley, Blair Murphy. Right to Ride: Streetcar Boycotts and African American Citizenship in the Era of Plessy v. Ferguson. Chapel Hill, NC: The University of North Carolina Press, 2010.

Kelley, Robin D. G. Freedom Dreams: The Black Radical Imagination. Boston, MA: Beacon Press, 2002.

Kelsey, Marie Ellen. Ulysses S. Grant: A Bibliography. Westport, CT: Praeger, 2005.

Kennedy, David M. Over Here: The First World War and American Society. New York: Oxford University Press, 1980.

Kennedy, Randall. The Persistence of the Color Line: Racial Politics and the Obama Presidency. New York: Pantheon, 2011.

Kens, Paul. Justice Stephen Field Shaping Liberty from the Gold Rush to the Gilded Age. Lawrence, Kan: University Press of Kansas, 1997.

Kent, Zachary. William Seward: The Mastermind of the Alaska Purchase. Berkeley Heights, NJ: Enslow Publishers, 2001.

Keohane, Robert O. und Nye, Joseph S. Power and Interdependence. Boston: Longman, 2012.

Keren, Michael and Sylvan, Donald A. International Intervention: Sovereignty versus Responsibility. Portland, OR: F. Cass, 2002.

Kerl, Kristoff. „To Restore Home Rule“: Angloamerikanische Männlichkeit und Antisemitismus im US-Süden zwischen den 1860er und 1920er Jahren. Dissertation, Universität zu Köln, 2015.

Kerrigan, Michael. American Presidents: A Dark History. New York: Metro Books, 2013.

Kersten, Stephen A. Housing Regulation and Reform in Boston, 1822-1924: Antecedents of Zoning. Waltham, MA: Brandeis University, 1973.

Kessler, Walter. Carl Schurz: Kampf, Exil und Karriere. Köln: Greven, 2006.

Kessner, Thomas. Capital City: New York City and the Men behind America's Rise to Economic Dominance, 1860-1900. New York: Simon \& Schuster, 2003.

Ketchersid, William Lester. The Gilded Age Presidency Reconsidered. Bloomington, IN: 1st Books Library, 2003.

Khagram, Sanjeev und Levitt, Peggy. The Transnational Studies Reader: Intersections and Innovations. New York: Routledge, 2008.

Khan, M. A. Muqtedar. „The Postmodern Empire: The United States' New Foreign Policy and its Global Challanges." The Brown Journal of World Affairs 2004, 10 (2):271-283.

Kidwell, Clara Sue. The Choctaws in Oklahoma: From Tribe to Nation, 1855-1970. Norman, OK: University of Oklahoma Press, 2007. 
Kindahl, James K. „Economic Factors in Specie Resumption: The United States, 1865-1879.“ In: Robert William Fogel und Stanley L. Engerman (Hg.). The Reinterpretation of American Economic History. New York: Harper \& Row, 1971, S. 468- 479.

Kindleberger, Charles Poor. Economic Response: Comparative Studies in Trade, Finance, and Growth. Cambridge, MA: Harvard University Press, 1978.

King, Wilma. Stolen Childhood: Slave Youth in Nineteenth-Century America. Bloomington, IN: Indiana University Press, 2011.

Kingston, Maxine Hong. China Men. New York: Vintage Books, 1989.

Kinshasa, Kwando Mbiassi. Black Resistance to the Ku Klux Klan in the Wake of the Civil War. Jefferson, NC: McFarland \& Co, 2006.

Kipnis, Ira. The American Socialist Movement, 1897-1912. New York: Monthly Review Press, 1972.

Klass, Tobias N. „Jenseits von Ahnen und Erben: Nietzsches Ereignis.“ In: Marc Rölli (Hg.). Ereignis auf Französisch: Von Bergson bis Deleuze. München: Wilhelm Fink, 2004, S. $43-61$.

Klein, Maury. The Life and Legend of Jay Gould. Baltimore, MD: Johns Hopkins University Press, 1986.

Kleinsteuber, Hans J. Staatsintervention und Verkehrspolitik in den USA: Die Interstate Commerce Commission. Ein Beitrag zur politischen Ökonomie der Vereinigten Staaten von Amerika. Stuttgart: Metzler, 1977.

Kline, Benjamin. First along the River: A Brief History of the U.S. Environmental Movement. Lanham, MD: Rowman \& Littlefield, 2007.

Kluger, Richard und Kluger, Phyllis. The Paper: The Life and Death of the New York Herald Tribune. New York: Knopf, 1986.

Knight, Alan. The Mexican Revolution. Lincoln, NE: University of Nebraska Press, 1990.

Knoedelseder, William. Bitter Brew: The Rise and Fall of Anheuser-Busch and America's Kings of Beer. New York: HarperBusiness, 2012.

Knoles, George Harmon. The Presidential Campaign and Election of 1892. New York: AMS Press, 1971.

Kocka, Jürgen. „Der ,Deutsche Sonderweg“ in der Diskussion.“ German Studies Review 5, no. 3 (1982):365-79.

Kocka, Jürgen. und Haupt, Heinz-Gerhard. Comparative History and the Quest for Transnationality: Central European Approaches and New Perspectives. New York: Berghahn Books, 2009.

Koenen, Anne. Mail-Order Catalogs in the US, 1880-1930: How Sears Brought Modernization to American Farmers. Paderborn: Universität Paderborn, 2001.

Koestler-Grack, Rachel A. William Tecumseh Sherman. New York: Chelsea House Publishers, 2009.

Kohn, George C. The New Encyclopedia of American Scandal. New York: Facts on File, 2001.

Koht, Halvdan. „The Origin of Seward's Plan to Purchase the Danish West Indies.“ The American Historical Review 50, no. 4 (1945):762-767.

Kohut, Andrew und Bruce Stokes. America against the World: How We Are Different and Why We Are Disliked. New York: Times Books, 2006.

Konvitz, Milton R. und Theodore Leskes. A Century of Civil Rights. New York: Columbia University Press, 1961. 
Kornbluh, Joyce L, Fred Thompson und Franklin Rosemont. Rebel Voices: An IWW Anthology. Oakland, CA: PM Press, 2011.

Korngold, Ralph. Thaddeus Stevens: A Being Darkly Wise and Rudely Great. Westport, CT: Greenwood Press, 1974.

Koselleck, Reinhart und Wolf-Dieter Stempel. Geschichte: Ereignis und Erzählung. München: W. Fink, 1973.

Kotek, Joèl und Pierre Rigoulot. Le Siècle des Camps: Détention, Concentration, Extérmination. Cent Ans de Mal Radical. Paris: Lattès, 2000.

Kouwenhoven, John Atlee. Partners in Banking: An Historical Portrait of a Great Private Bank, Brown Brothers, Harriman \& Co., 1818-1968. Garden City, NY: Doubleday, 1983.

Krader, Lawrence und Kovalevskii, M. M. The Asiatic Mode of Production: Sources, Development and Critique in the Writings of Karl Marx. Assen: Van Gorcum, 1975.

Kraditor, Aileen S. The Radical Persuasion, 1890-1917: Aspects of the Intellectual History and the Historiography of Three American Radical Organizations. Baton Rouge, LA: Louisiana State University Press, 1981.

Krall, Lisi. „US Land Policy and the Commodification of Arid Land (1862-1920).“ Journal of Economic Issues 35, no. 3 (2001):657-674.

Krass, Peter. Carnegie. Hoboken, NJ: John Wiley \& Sons, 2002.

Krause, Paul. The Battle for Homestead, 1880-1892: Politics, Culture, and Steel. Pittsburgh, PA: University of Pittsburgh Press, 1992.

Kremer, Gary R. George Washington Carver: A Biography. Santa Barbara, CA: Greenwood, 2011. Krooth, Richard. A Century Passing: Carnegie, Steel and the Fate of Homestead. Lanham, MD: University Press of America, 2002.

Küçükyazici, Günes. „Literature Review on Organizational Path Dependence.“ GAU Journal of Social and Applied Sciences. 2014, 6 (10):60-72.

Kulenkampff, Angela. Österreich und das Alte Reich: Die Reichspolitik des Staatskanzlers Kaunitz unter Maria Theresia und Joseph II. Köln: Böhlau, 2005.

Kuznets, Simon Smith. Capital in the American Economy: Its Formation and Financing. Princeton, NJ: Princeton University Press, 1961.

Kynell-Hunt, Teresa. Writing in a Milieu of Utility: The Move to Technical Communication in American Engineering Programs, 1850-1950. Norwood, NJ: Ablex Pub. Corp, 1996.

Köhler, Angelika. „Charged with Ambiguity: The Image of the New Woman in American Cartoons.“ In: Ann Heilmann und Margaret Beetham (Hg.). New Woman Hybridities: Feminity, Feminism and International Consumer Culture, 1880-1930. London, New York: Routledge, 2004, S. $158-178$.

Labbé, Ronald M. und Jonathan Lurie. The Slaughterhouse Cases: Regulation, Reconstruction, and the Fourteenth Amendment. Lawrence, KS: University Press of Kansas, 2005.

Laclau, Ernesto und Chantal Mouffe. Hegemony and Socialist Strategy: Towards a Radical Democratic Politics. London, New York: Verso, 2014.

LaFeber, Walter. Inevitable Revolutions: The United States in Central America. New York: W.W. Norton, 1993.

LaFeber, Walter. The New Empire: An Interpretation of American Expansion, 1860-1898. Ithaca, NY: Cornell University Press, 1998.

LaFeber, Walter. „The ,Lion in the Path': The U. S. Emergence as a World Power." Political Science Quarterly 1986, 101 (5):705-718, 
LaFeber, Walter. „The Tension between Democracy and Capitalism during the American Century.“ In: Hogan, Michael J. (Hg.). The Ambiguous Legacy U.S. Foreign Relations in the „American Century.“ Cambridge, New York: Cambridge University Press, 1999, S. $152-182$.

Lafferty, William M. und Ruud, Audun. Promoting Sustainable Electricity in Europe: Challenging the Path Dependence of Dominant Energy Systems. Cheltenham, Northampton, MA: Edward Elgar, 2008.

Laird, Pamela Walker. Advertising Progress: American Business and the Rise of Consumer Marketing. Baltimore, MD: The Johns Hopkins University Press, 1998.

Lamont-Brown, Raymond. Carnegie the Richest Man in the World. Thrupp, Stroud, Gloucestershire: Sutton Pub, 2005.

Lamoreaux, Naomi R. History Matters: Essays on Economic Growth, Technology, and Demographic Change by Timothy W. Guinnane, William A. Sundstrom, Warren Whatley. Journal of Economic Literature 43, no. 4 (2005):1065-1066.

Lampert, Jay. Deleuze and Guattari's Philosophy of History. London, New York: Continuum, 2006.

Lancaster, William. The Department Store a Social History. London, New York: Leicester University Press, 1995.

Landon-Lanbe, John, Hugh Rockoff und Richard H. Steckel. „Droughts, Floods, and Financial Distress in the United States. “In: Gary D. Libecap und Richard H. Steckel (Hg.). The Economics of Climate Change: Adaptations Past and Present. Chicago, IL, London: The University of Chicago Press, 2011, S. 73-98.

Lane, Ambrose I. For Whites Only? How and Why America Became a Racist Nation. Bloomington, IN: AuthorHouse, 2008.

Lane, Charles. The Day Freedom Died: The Colfax Massacre, the Supreme Court, and the Betrayal of Reconstruction. New York: Henry Holt and Co, 2008.

Langley, Lester D. und Thomas David Schoonover. The Banana Men: American Mercenaries and Entrepreneurs in Central America, 1880-1930. Lexington, KY: University Press of Kentucky, 1995.

Langum, David J. Crossing Over the Line: Legislating Morality and the Mann Act. Chicago, IL: The University of Chicago Press, 1994.

Lantis, Jeffrey S. US Foreign Policy in Action: An Innovative Teaching Text. Chichester: John Wiley \& Sons, 2013.

Lanza, Michael L. Agrarianism and Reconstruction Politics: The Southern Homestead Act. Baton Rouge, LA: Louisiana State University, 1990.

Largent, Mark A. Breeding Contempt: The History of Coerced Sterilization in the United States. New Brunswick, NJ: Rutgers University Press, 2008.

Larner, John B. „List of Principal Municipal Authorities of the Cities of Washington, Georgetown and the District of Columbia." Records of the Columbia Historical Society, Washington, DC 23 (1920):180-187.

Larsen, Lawrence H. und Nancy J Hulston. Pendergast! Columbia, MO: University of Missouri Press, 1997.

Larson, Erik. The Devil in the White City: Murder, Magic, and Madness at the Fair That Changed America. New York: Crown Publishers, 2003. 
Larson, John Lauritz. „,Bind the Republic Together': The National Union and the Struggle for a

System of Internal Improvements.“ The Journal of American History. 1987,

74 (2):363-387.

Lasch, Christopher. Haven in a Heartless World: The Family Besieged. New York: Basic Books, 1977.

Latham, Frank Brown. The Rise and Fall of Jim Crow, 1865-1964. New York: F. Watts, 1969.

Laufer, William S. Corporate Bodies and Guilty Minds: The Failure of Corporate Criminal

Liability. Chicago, IL: University of Chicago Press, 2006.

Laughlin, Rosemary. John D. Rockefeller: Oil Baron and Philanthropist. Greensboro, NC:

Morgan Reynolds Pub, 2004.

Laughlin, Rosemary. The Pullman Strike of 1894. Greensboro, NC: Morgan Reynolds Pub, 2006.

Laurie, Bruce. Artisans into Workers: Labor in Nineteenth-Century America. Urbana, IL: University of Illinois Press, 1997.

Laurie, Clayton D. und Ronald H. Cole. The Role of Federal Military Forces in Domestic Disorders, 1877-1945. Washington, DC: Center of Military History, U.S. Army. For sale by Supt. of Docs, Government Printing Office, 1997.

Lawrence, Frederick M. „Civil Rights and Criminal Wrongs: The Mens Rea of Federal Rights Crimes.“ Tulane Law Review 67 (1993):2113-2229.

Lawson, Colin W. „Path-Dependence and the Economy of Belarus: The Consequences of Late

Reform." In: Korosteleva, Elena A., Lawson, Colin W., Marsh, Rosalind J. (Hg.).

Contemporary Belarus: Between Democracy and Dictatorship. London, New York:

RoutledgeCurzon, 2003, S. 125-136.

Leach, William. Land of Desire: Merchants, Power, and the Rise of a New American Culture. New York: Pantheon Books, 1993.

Leannah, Michael. Something for Everyone Memories of Lauerman Brothers Department Store. Madison, WI: Wisconsin Historical Society Press, 2013.

Lebergott, Stanley. The Americans: An Economic Record. New York: W.W. Norton, 1984.

Lederhendler, Eli. Jewish Immigrants and American Capitalism, 1880-1920: From Caste to Class. Cambridge, New York: Cambridge University Press, 2009.

Ledford, Kenneth F. „Comparing Comparisons: Disciplines and the Sonderweg.“ Central European History 36, no. 3 (2003):367-374.

Lee, Anne Feder. The Hawai'i State Constitution. Oxford, New York: Oxford University Press, USA, 2011.

Lee, Shelley Sang-Hee. A New History of Asian America. New York: Routledge, 2014.

Lehmann, Silke. „Lorenz von Stein über den amerikanischen Sozialismus und Kommunismus.“ In: Finzsch, Norbert und Wellenreuther, Hermann (Hg.). Liberalitas: Festschrift für Erich Angermann zum 65. Geburtstag. Stuttgart: Franz Steiner Verlag, 1992, S. 207-222.

Lehmkuhl, Ursula. „Diplomatiegeschichte als internationale Kulturgeschichte: Theoretische Ansätze und empirische Forschung zwischen Historischer Kulturwissenschaft und Soziologischem Institutionalismus.“ Geschichte und Gesellschaft. 2001, 27 (3):394-423

Lehmkuhl, Ursula. Pax Anglo-Americana: Machtstrukturelle Grundlagen anglo-amerikanischer Asien- und Fernostpolitik in den 1950er Jahren. München: Oldenbourg, 1999.

Lehmkuhl, Ursula, Eva Bischoff und Norbert Finzsch (Hg.). Provincializing the United States: Colonialism, Decolonization, and (Post)Colonial Governance in Transnational Perspective. Heidelberg: Winter, 2014. 
Lehrer, Susan. Origins of Protective Labor Legislation for Women, 1905-1925. Albany: State University of New York Press, 1987.

Leiken, Robert S. A New Moment in the Americas. New Brunswick, N): Transaction Publishers, 1994.

Lens, Sidney. The Crisis of American Labor. New York: Sagamore Press, 1959.

Lens, Sidney. The Labor Wars: From the Molly Maguires to the Sitdowns. Garden City, NY: Doubleday, 1973.

Lens, Sidney. The Forging of the American Empire. London, Sterling, VA, Chicago, IL: Pluto Press. Haymarket Books, 2003.

Lepsius, Oliver. Verwaltungsrecht unter dem Common Law: Amerikanische Entwicklungen bis zum New Deal. Tübingen: Mohr Siebeck, 1997.

Letwin, William. Law and Economic Policy in America: The Evolution of the Sherman Antitrust Act. Chicago, IL: University of Chicago Press, 1981.

Lewin, Roger. In the Age of Mankind: A Smithsonian Book of Human Evolution. Washington, DC: Smithsonian Books, 1988.

Lewy, Guenter. Were American Indians the Victims of Genocide? [Web Page]: http:// historynewsnetwork.org/article/7302. Gesehen am 13. April 2015.

Li, Linda Chelan. Rural Tax Reform in China: Policy Process and Institutional Change. London, New York: Routledge, 2012.

Libecap, Gary D. und Zeynep K. Hansen. „,Rain Follows the Plow’ and Dryfarming Doctrine: The Climate Information Problem and the Homestead Failure in the Upper Great Plains, 1890-1915.“ Journal of Economic History 62, no. 1 (2002):86-120.

Liddic, Bruce R. Vanishing Victory: Custer's Final March. El Segundo, CA: Upton \& Sons, Publishers, 2004.

Lieberman, Robert C. „The Freedmen's Bureau and the Politics of Institutional Structure.“ Social Science History 18, no. 3 (1994):405- 437.

Liebowitz, Stan J. und Stephen E. Margolis. „The Fable of the Keys.“ Journal of Law and Economics 33, no. 1 (1990):1-25.

Liebowitz, Stan J. und Stephen E. Margolis. „Path Dependence, Lock-In, and History.“ [Web Page]: https://www.researchgate.net/publication/5213887. Gesehen am 5. Mai 2016.

Liebowitz, Stan J. und Stephen E. Path Dependence and Lock-In. Cheltenham, Northampton, MA: Edward Elgar Publishing, 2014.

Limerick, Patricia Nelson. The Legacy of Conquest: The Unbroken Past of the American West. New York: W.W. Norton, 2006.

Lind, Michael. What Lincoln Believed: The Values and Convictions of America's Greatest President. New York: Doubleday, 2005.

Linder, Marc. „Time and a Half's the American Way“: A History of the Exclusion of White-Collar Workers from Overtime Regulation, 1868-2004. lowa City, IO: Fanpihua Press, 2004.

Lindquist, Malinda A. Race, Social Science and the Crisis of Manhood, 1890-1970: We Are the Supermen. New York: Routledge, 2012.

Lindsay, Brendan C. Murder State: California's Native American Genocide, 1846-1873. Lincoln, NE: University of Nebraska Press, 2012.

Lindsey, Almont. The Pullman Strike: The Story of a Unique Experiment and of a Great Labor Upheaval. Chicago, IL: University of Chicago Press, 1964. 
Lindstrom, Richard. „,Not from the Land Side, but from the Flag Side’: Native American Responses to the Wanamaker Expedition of 1913.“ Journal of Social History. 1996, 30 (1):209-227.

Link, Arthur Stanley. Woodrow Wilson and a Revolutionary World, 1913-1921. Chapel Hill, NC: University of North Carolina Press, 1982.

Link, Arthur Stanley. Woodrow Wilson and the Progressive Era, 1910-1917. New York: Harper, 1954.

Linn, Brian McAllister. Guardians of Empire: The U.S. Army and the Pacific, 1902-1940. Chapel Hill, NC: University of North Carolina Press, 1997.

Linn, Brian McAllister. The Philippine War, 1899-1902. Lawrence, KS: University Press of Kansas, 2000.

Linn, Brian McAllister. The U.S. Army and Counterinsurgency in the Philippine War, 1899-1902. Chapel Hill, NC: University of North Carolina Press, 1989.

Lippke, Richard L. „The Disenfranchisement of Felons.“ Law and Philosophy 20, no. 6 (2001):553-580.

Lipset, Seymour Martin. American Exceptionalism: A Double-Edged Sword. New York: W.W. Norton, 1996.

List, Martin, Behrens, Maria, Reichardt, Wolfgang und Simonis, Georg. Internationale Politik: Probleme und Grundbegriffe. Opladen: VS Verlag für Sozialwissenschaften, 1995.

Litwack, Leon F. The American Labor Movement. Englewood Cliffs, NJ: Prentice-Hall, 1962.

Litwack, Leon F. Been in the Storm So Long: The Aftermath of Slavery. New York: Vintage Books, 1980.

Litwack, Leon F. How Free Is Free? The Long Death of Jim Crow. Cambridge, MA: Harvard University Press, 2009.

Litwak, Robert. Regime Change: U.S. Strategy through the Prism of 9/11. Washington, DC, Baltimore, MD: Woodrow Wilson Center Press. Johns Hopkins University Press, 2007.

Livesay, Harold C. Andrew Carnegie and the Rise of Big Business. New York: Pearson Longman, 2007.

Lockey, Joseph Byrne. Orígenes del Panamericanismo. Caracas: Gobierno de Venezuela, 1976. Lösche, Peter (Hg.). Länderbericht USA: Geschichte, Politik, Wirtschaft, Gesellschaft, Kultur. Bonn: Bundeszentrale für Politische Bildung, 2008.

Lofgren, Charles A. „United States v. Curtiss-Wright Export Corporation: An Historical Reassessment." The Yale Law Journal 83, no. 1 (1973):1-32.

Logan, Shirley W. We Are Coming: The Persuasive Discourse of Nineteenth-Century Black Women. Carbondale, IL: Southern Illinois University Press, 1999.

Loheide, Boris. „Agrobusiness und Globalisierung: Die Entstehung des transatlantischen Rindfleischmarktes 1870-1914.“ Dissertation, Universität zu Köln, 2008.

Lomas, Charles Wyatt. The Agitator in American Society. Englewood Cliffs, NJ: Prentice-Hall, 1968.

Lombardo, Paul A. Three Generations, No Imbeciles: Eugenics, the Supreme Court, and Buck v. Bell. Baltimore, MD: Johns Hopkins University Press, 2008.

Lombardo, Paul A. A Century of Eugenics in America: From the Indiana Experiment to the Human Genome Era. Bloomington, IN: Indiana University Press, 2011.

Lord, Walter. The Good Years: From 1900 to the First World War. New Brunswick, NJ: Transaction Publishers, 2011. 
Lowe, Richard. „The Freedmen's Bureau and Local Black Leadership.“ The Journal of American History 80, no. 3 (1993):989-998.

Lowe, Richard. „The Freedmen's Bureau and Local White Leaders in Virginia.“ The Journal of Southern History 64, no. 3 (1998): 455- 472.

Lubetkin, M. John. Jay Cooke's Gamble: The Northern Pacific Railroad, the Sioux, and the Panic of 1873. Norman, OK: University of Oklahoma Press, 2006.

Lubove, Roy. The Progressives and the Slums: Tenement House Reform in New York City, 1890-1917. Westport, CT: Greenwood Press, 1974.

Luecke, John. The Great Northern in Minnesota: The Foundations of an Empire. St. Paul, MN: Grenadier Publications, 1997.

Luedtke, Luther S. Nathaniel Hawthorne and the Romance of the Orient. Bloomington, IN: Indiana University Press, 1989.

Lukes, Bonnie L. Woodrow Wilson and the Progressive Era. Greensboro, N.C: Morgan Reynolds Pub, 2006.

Lurie, Jonathan. „H. D. Lloyd: A Note.“ Agricultural History 47, no. 1 (1973):76-79.

Lynch, Denis Tilden. „Boss“ Tweed the Story of a Grim Generation. New Brunswick, N): Transaction Publishers, 2002.

Lynch, John Roy. Reminiscences of an Active Life: The Autobiography of John Roy Lynch. Chicago, IL: University of Chicago Press, 1970.

Lüthi, Barbara. „Invading Bodies“: Medizin und Immigration in den USA (1880-1920). Frankfurt am Main, New York: Campus, 2009.

Mach, Thomas S. „Gentleman George“ Hunt Pendleton: Party Politics and Ideological Identity in Nineteenth-Century America. Kent, OH: Kent State University Press, 2007.

Mackay, James A. Allan Pinkerton: The First Private Eye. New York: J. Wiley \& Sons, 1997. Madsen, Axel. The Marshall Fields. New York: J. Wiley, 2002.

Madsen, Deborah L. American Exceptionalism. Jackson, MS: University Press of Mississippi, 1998.

Magdalena, Federico V. The Battle of Bayang and Other Essays on Moroland. Marawi City, Philippines: Mamitua Saber Research Center, Office of the Vice Chancellor for Research \& Extension, Mindanao State University, 2002.

Magness, Phillip W. und Weissburg, Paul. Rules of the Game: How Government Works and Why It Sometimes Doesn't. Prince Frederick, MD: Recorded Books, 2011.

Magnusson, Lars und Ottosson, Jan. The Evolution of Path Dependence. Cheltenham, Northampton, MA: Edward Elgar, 2009.

Magnusson, Lars und Ottosson, Jan. Evolutionary Economics and Path Dependence. Cheltenham, Northampton, MA: Edward Elgar Publishing, 1997.

Magrath, C. Peter. Morrison R. Waite: The Triumph of Character. New York: Macmillan, 1963.

Mahoney, James und Schensul, Daniel. „Historical Context and Path Dependence.“ In: Robert

E. Goodin und Charles Tilly (Hg.). The Oxford Handbook of Contextual Political Analysis. Oxford: Oxford University Press, 2006, S. 454-471.

Mahoney, James und Thelen, Kathleen Ann. Explaining Institutional Change Ambiguity, Agency, and Power. Cambridge, New York: Cambridge University Press, 2010.

Mahoney, James. „Path Dependence in Historical Sociology.“ Theory and Society. 2000, 29 (4):507-548.

Mahoney, James. The Legacies of Liberalism: Path Dependence and Political Regimes in Central America. Baltimore, MD: Johns Hopkins University Press, 2001. 
Maier, Charles S. Among Empires: American Ascendancy and Its Predecessors. Cambridge, MA: Harvard University Press, 2006.

Maier, Charles S. „Empire's Past... Empire’s Future.“ South Central Review 2009, 26 (3):2-19.

Maihafer, Harry J. The General and the Journalists: Ulysses S. Grant, Horace Greeley, and Charles Dana. Washington, DC: Brassey's, 1998.

Malone, Ann Patton. „Piney Woods Farmers of South Georgia, 1850-1900: Jeffersonian Yeomen in an Age of Expanding Commercialism. “ Agricultural History. 1986, 60 (4):51-84.

Malone, Michael P., Roeder, Richard B. und Lang, William L. Montana: A History of Two Centuries. Seattle, WA: University of Washington Press, 1991.

Maltz, Earl M. The Fourteenth Amendment and the Law of the Constitution. Durham, NC: Carolina Academic Press, 2003.

Mancall, Peter und Heber Johnson, Benjamin (Hg.). Making of the American West: People and Perspectives. Santa Barbara, CA: ABC-CLIO, 2007.

Mann, Susan A. „Slavery, Sharecropping, and Sexual Inequality.“ Signs 14, no. 4 (1989):774-798.

Manza, Jeff und Uggen, Christopher. „Punishment and Democracy: Disenfranchisement of Nonincarcerated Felons in the United States." Perspectives on Politics 2, no. 3 (2004):491-505.

Marcus, Alan I. Agricultural Science and the Quest for Legitimacy: Farmers, Agricultural Colleges, and Experiment Stations, 1870-1890. Ames, IO: Iowa State University Press, 1985.

Margulies, Phillip und Maxine Rosaler. The Devil on Trial: Witches, Anarchists, Atheists, Communists, and Terrorists in America's Courtrooms. Boston, MA: Houghton Mifflin Co, 2008.

Marinski, Deborah R. William McKinley: A Modern Man. New York: Nova Science Publishers, 2011.

Markel, Rita J. Grover Cleveland. Minneapolis, MN: Twenty-First Century Books, 2007.

Markham, Jerry W. A Financial History of the United States. Armonk, NY: M. E. Sharpe, 2002.

Marquard, Leopold. South Africa's Colonial Policy: Presidential Address Delivered at the Annual Meeting of the Council of the South African Institute of Race Relations in the Hiddingh Hall, Cape Town, on January 16, 1957. Johannesburg: The Institute, 1957.

Marschall, Richard. Bully! The Life and Times of Theodore Roosevelt. Washington, D.C, New York: Regnery Pub. Distributed to the trade by Perseus Distribution, 2011.

Marshall, F. Ray. Labor in the South. Cambridge, MA: Harvard University Press, 1967.

Marshall, James M. Land Fever: Dispossession and the Frontier Myth. Lexington, KY: University Press of Kentucky, 1986.

Marti, Donald B. Women of the Grange: Mutuality and Sisterhood in Rural America, 1866-1920. New York: Greenwood Press, 1991.

Martin, Cathie J. und Duane Swank. The Political Construction of Business Interests: Coordination, Growth, and Equality. Cambridge, New York: Cambridge University Press, 2012.

Martin, Ron. „Roepke Lecture in Economic Geography: Rethinking Regional Path Dependence: Beyond Lock-in to Evolution.“ Economic Geography 2010, 86 (1):1-28

Martínez-Fernández, Luis. Protestantism and Political Conflict in the Nineteenth-Century Hispanic Caribbean. New Brunswick, NJ: Rutgers University Press, 2002. 
Martinez, J. Michael. Carpetbaggers, Cavalry, and the Ku Klux Klan: Exposing the Invisible Empire during Reconstruction. Lanham, MD: Rowman \& Littlefield, 2007.

Matsen, William E. „The Battle of Sugar Point: A Re-Examination.“ Minnesota History. 1987, 50 (7):269-275.

Matthews, Glenna. „Just a Housewife“: The Rise and Fall of Domesticity in America. New York: Oxford University Press, 1987.

Matthews, Peter Hans. „Positive Feedback and Path Dependence: Using the Law of Large Numbers." The Journal of Economic Education 2001, 32 (2):124-136.

Mattison, Ray H. „The Hard Winter and the Range Cattle Business.“ The Montana Magazine of History. 1951 Oct 1, 1 (4):5-21.

Mau, Steffen. Social Transnationalism: Lifeworlds beyond the Nation-State. London, New York: Routledge, 2010.

May, Ernest R. The Making of the Monroe Doctrine. Cambridge, MA: Belknap Press of Harvard University Press, 1975.

May, Ernest R., Rosecrance, Richard N. und Steiner, Zara (Hg.). History and Neorealism. Cambridge, New York: Cambridge University Press, 2010.

May, Robert E. The Southern Dream of a Caribbean Empire, 1854-1861. Gainesville, FL: University Press of Florida, 2002.

Mayhew, Anne. Narrating the Rise of Big Business in the USA: How Economists Explain Standard Oil and Wal-Mart. London, New York: Routledge, 2008.

Mayhew, David R. Parties and Policies: How the American Government Works. New Haven, CT: Yale University Press, 2008.

Mazour, Anatole G. „The Prelude to Russia’s Departure from America.“ Pacific Historical Review 10, no. 3 (1941):311-319.

McAlpine, R. W. The Life and Times of Col. James Fisk, Jr. New York: Arno Press, 1981.

McBride, Mary Gorton und Ann M. McLaurin. Randall Lee Gibson of Louisiana: Confederate General and New South Reformer. Baton Rouge, LA: Louisiana State University Press, 2007.

McBride, Paul. Culture Clash: Immigrants and Reformers, 1880-1920. San Francisco, CA: R and E Research Associates, 1975.

McConnell, Stuart Charles. Glorious Contentment: The Grand Army of the Republic, 1865-1900. Chapel Hill: University of North Carolina Press, 1992.

McCormick, Charles H. Seeing Reds: Federal Surveillance of Radicals in the Pittsburgh Mill District, 1917-1921. Pittsburgh, PA: University of Pittsburgh Press, 1997.

McCormick, James M. American Foreign Policy and Process. Belmont, CA: Cengage Learning Wadsworth, 2014.

McCormick, Thomas J. China Market: America's Quest for Informal Empire, 1893-1901. Chicago, IL: I.R. Dee, 1990.

McCulley, Richard T. Banks and Politics during the Progressive Era: The Origins of the Federal Reserve System, 1897-1913. New York: Garland Pub, 1992.

McDougall, Walter A. Promised Land, Crusader State: The American Encounter with the World since 1776. Boston: Houghton Mifflin, 1997.

McDougall, Walter A. „What the U.S. Needs to Promote in Iraq (Hint: It's Not Democratization Per Se).“ Foreign Policy Research Institute Wire 11, no. 2 (2003).

McDougall, Walter A. „Back to Bedrock: The Eight Traditions of American Statecraft.“ Foreign Affairs 1997, 76 (2):134-146. 
McFarland, Gerald W. Inside Greenwich Village: A New York City Neighborhood, 1898-1918. Amherst: University of Massachusetts Press, 2001.

McFarland, Gerald W. Mugwumps, Morals, \& Politics, 1884-1920. Amherst: University of Massachusetts Press, 1975.

McFeely, William S. Yankee Stepfather: General O. O. Howard and the Freedmen. New Haven, CT: Yale University Press, 1968.

McGerr, Michael E. A Fierce Discontent: The Rise and Fall of the Progressive Movement in America, 1870-1920. New York: Free Press, 2003.

McGovern, Charles. Sold American: Consumption and Citizenship, 1890-1945. Chapel Hill, NC: University of North Carolina Press, 2006.

McGuire, Shawn J. „Path-Dependency in Plant-Breeding: Challenges Facing Participatory Reforms in the Ethiopian Sorghum Improvement Program.“ Agricultural Systems 96, no. 1-3 (2008):139-149.

McHugh, Cathy L. Mill Family: The Labor System in the Southern Cotton Textile Industry, 1880-1915. New York: Oxford University Press, 1988.

McHugh, Kathleen Anne. American Domesticity: From How-to Manual to Hollywood Melodrama. New York: Oxford University Press, 1999.

Mclver, Stuart B. Dreamers, Schemers, and Scalawags. Sarasota, FL: Pineapple Press, 1994.

Mcjimsey, George T. Harry Hopkins: Ally of the Poor and Defender of Democracy. Cambridge, MA: Harvard University Press, 1987.

McLennan, Kathleen A. „Woman's Place: ,Marriage“ in America’s Gilded Age.“ Theatre Journal 37, no. 3 (1985):345-356.

McMaster, Lindsey. Working Girls in the West: Representations of Wage-Earning Women. Vancouver: UBC Press, 2008.

McMath, Robert C. American Populism: A Social History, 1877-1898. New York: Hill and Wang, 1993.

McMurry, Donald Le Crone. Coxey's Army: A Study of the Industrial Army Movement of 1894. New York: AMS Press, 1970.

McNeese, Tim. The Gilded Age and Progressivism, 1891-1913. New York: Chelsea House, 2009.

McNeese, Tim. The Robber Barons and the Sherman Anti-Trust Act: Reshaping American Business. New York: Chelsea House Publishers, 2009.

McPherson, James M. Abraham Lincoln and the Second American Revolution. New York: Oxford University Press, 1990.

McPherson, James M. Battle Cry of Freedom: The Civil War Era. New York: Oxford University Press, 1988.

McPherson, James M. Ordeal by Fire: The Civil War and Reconstruction. Boston, MA: McGraw-Hill, 2001.

McPherson, James M. The Struggle for Equality: Abolitionists and the Negro in the Civil War and Reconstruction. Princeton, NJ: Princeton University Press, 1964.

McWhirter, Cameron. Red Summer: The Summer of 1919 and the Awakening of Black America. New York: Henry Holt \& Co, 2011.

Mead, Sidney E. „American Protestantism since the Civil War. II. From Americanism to Christianity." The Journal of Religion 36, no. 2 (1956):67-89.

Meier, Christian. Der Historiker und der Zeitgenosse: Eine Zwischenbilanz. München: Siedler, 2014. 
Meissner, Werner. China zwischen Nationalem ,Sonderweg' und universaler Modernisierung: Zur Rezeption westlichen Denkens in China. München: W. Fink, 1994.

Mercer, Lloyd J. Railroads and Land Grant Policy: A Study in Government Intervention. New York: Academic Press, 1982.

Merk, Frederick. The Monroe Doctrine and American Expansionism, 1843-1849. New York: Knopf, 1966.

Merriner, James L. Grafters and Goo Goos: Corruption and Reform in Chicago, 1833-2003. Carbondale, IL: Southern Illinois University Press, 2004.

Messer-Kruse, Timothy. The Haymarket Conspiracy: Transatlantic Anarchist Networks. Urbana, IL: University of Illinois Press, 2012.

Messer-Kruse, Timothy. The Trial of the Haymarket Anarchists: Terrorism and Justice in the Gilded Age. New York: Palgrave Macmillan, 2011.

Messner, Steven F., Baller, Robert D. und Zevenbergen, Matthew P.. „The Legacy of Lynching and Southern Homicide.“ American Sociological Review 70, no. 4 (2005):633-655.

Meyer, Howard N. The Amendment That Refused to Die: Equality and Justice Deferred. The History of the Fourteenth Amendment. Lanham, MD: Madison Books, 2000.

Meyer, Michael C. „Felix Sommerfeld and the Columbus Raid of 1916.“ Arizona and the West 25, no. 3 (1983): $213-228$.

Meyer, Michael C. „The Mexican-German Conspiracy of 1915.“ The Americas 23, no. 1 (1966): $76-89$.

Meyer, Michael C. „Villa, Sommerfeld, Columbus y los Alemanes.“ Historia Mexicana 28, no. 4 (1979): 546-566.

Meyer, Michael C, William L. Sherman und Susan M. Deeds. The Course of Mexican History. New York: Oxford University Press, 1999.

Meyerowitz, Joanne J. Women Adrift: Independent Wage Earners in Chicago, 1880-1930. Chicago, IL: University of Chicago Press, 1988.

Michael, Robert. A Concise History of American Antisemitism. Lanham, MD: Rowman \& Littlefield, 2005.

Michno, Gregory. Battle at Sand Creek: The Military Perspective. El Segundo, CA: Upton and Sons, Publishers, 2004.

Micklethwait, John und Wooldridge, Adrian. The Company: A Short History of a Revolutionary Idea. New York: Modern Library, 2003.

Milano, Kenneth W. Hidden History of Kensington \& Fishtown. Charleston, SC: History Press, 2010.

Milkis, Sidney M. und Mileur, Jerome M. . Progressivism and the New Democracy. Amherst: University of Massachusetts Press, 1999.

Miller, Donald L. City of the Century: The Epic of Chicago and the Making of America. New York: Simon \& Schuster, 1996.

Miller, George Hall. Railroads and the Granger Laws. Madison, WI: University of Wisconsin Press, 1971.

Miller, Marvin D. Terminating the „Socially Inadequate“: The American Eugenicists and the German Race Hygienists, California to Cold Spring Harbor, Long Island to Germany. Commack, NY: Malamud-Rose, 1996.

Miller, Melinda C. „Land and Racial Wealth Inequality.“ The American Economic Review 101, no. 3 (2011):371-76.

Miller, Nathan. Theodore Roosevelt: A Life. New York: Morrow, 1992. 
Miller, Nathan. New World Coming: The 1920s and the Making of Modern America. New York: Scribner, 2003.

Miller, Sally M. Victor Berger and the Promise of Constructive Socialism, 1910-1920. Westport, CT: Greenwood Press, 1973.

Miller, Stephen. Special Interest Groups in American Politics. New Brunswick, N): Transaction Books, 1983.

Miller, Worth Robert. „Farmes and Third Party Politics.“ In: Charles W. Calhoun (Hg.). The Gilded Age: Perspectives on the Origins of Modern America. Lanham, MD: Rowman \& Littlefield Publishers, 2007, S. 283-306.

Miller, Worth Robert. Populist Cartoons: An Illustrated History of the Third-Party Movement in the 1890s. Kirksville, MO: Truman State University Press, 2011.

Miller, Zane L. Boss Cox's Cincinnati: Urban Politics in the Progressive Era. Columbus, $\mathrm{OH}$ : Ohio State University Press, 2000.

Mills, Charles W. „Revisionist Ontologies: Theorizing White Supremacy.“ Social and Economic Studies. 1994, 43 (3):105-134.

Miner, H. Craig. The St. Louis-San Francisco Transcontinental Railroad: The Thirty-Fifth Parallel Project, 1853-1890. Lawrence, KS: University Press of Kansas, 1972.

Ministerium für Schule und Weiterbildung des Landes Nordrhein-Westfalen. Kernlehrplan für das Gymnasium - Sekundarstufe I (G8) in Nordrhein-Westfalen: Geschichte. Frechen: Ritterbach Verlag, 2007.

Mintz, Steven. African American Voices the Life Cycle of Slavery. St. James, NY: Brandywine Press, 1993.

Mintz, Steven und Kellogg, Susan. Domestic Revolutions: A Social History of American Family Life. New York, London: Free Press. Collier Macmillan, 1988.

Misa, Thomas J. A Nation of Steel: The Making of Modern America, 1865-1925. Baltimore, MD: Johns Hopkins University Press, 1995.

Missal, Alexander. Seaway to the Future: American Social Visions and the Construction of the Panama Canal. Madison, WI: University of Wisconsin Press, 2008.

Mitchell, Allan. The Great Train Race. Railways and the Franco-German Rivalry, 1815-1914. New York: Berghahn Books, 2000.

Mitchell, Mary Niall. Raising Freedom's Child: Black Children and Visions of the Future after Slavery. New York: New York University Press, 2008.

Mitchener, Kris James und Marc D. Weidenmier. Empire, Public Goods, and the Roosevelt Corollary. Cambridge, MA: National Bureau of Economic Research, 2004.

Mittelman, Amy. Brewing Battles: A History of American Beer. New York: Algora Pub, 2008.

Mitterauer, Michael. Die Entwicklung Europas: Ein Sonderweg? Legitimationsideologien und die Diskussion der Wissenschaft. Wien: Picus, 1999.

Mitterling, Doris. Guide to the Henry Moore Teller Papers, 1862-1908. Boulder, CO: Western Historical Collections, University of Colorado Libraries, 1974.

Mixon, Scott. „The Crisis of 1873: Perspectives from Multiple Asset Classes.“ The Journal of Economic History 68, no. 3 (2008):722-757.

Mizruchi, Susan L. The Science of Sacrifice: American Literature and Modern Social Theory. Princeton, NJ: Princeton University Press, 1998.

Mjagkij, Nina. Organizing Black America: An Encyclopedia of African American Associations. New York: Garland, 2001. 
Mock, Cary J. „Drought and Precipitation Fluctuations in the Great Plains during the Late Nineteenth Century.“ Great Plains Research: A Journal of Natural and Social Sciences, Paper 7, no. 1 (1991):26-57.

Moffat, William C. Soldier's Pay [Web Page]: http://www.cincinnaticwrt.org/data/ccwrt_ history/talks_text/moffat_soldiers_pay.html. Gesehen am 5. Januar 2017.

Mohr, Clarence L. „Before Sherman: Georgia Blacks and the Union War Effort, 1861-1864.“ The Journal of Southern History 45, no. 3 (1979):331-52.

Mombauer, Annika. „The Fischer Controversy, Documents and the ,Truth ' about the Origins of the First World War.“ Journal of Contemporary History 48, no. 2 (2013):290-314.

Moneyhon, Carl H. Arkansas and the New South, 1874-1929. Fayetteville, AR: University of Arkansas Press, 1997.

Montejano, David. Anglos and Mexicans in the Making of Texas, 1836-1986. Austin, TX: University of Texas Press, 1987.

Montgomery, David. The Fall of the House of Labor: The Workplace, the State, and American Labor Activism, 1865-1925. Cambridge, New York, Paris: Cambridge University Press. Editions de la Maison des Sciences de l'Homme, 1987.

Montgomery, David. „Workers' Control of Machine Production in the Nineteenth Century.“ In: Daniel J. Leab (Hg.). The Labor History Reader. Urbana, IL: University of Illinois Press, 1985, S. $107-131$.

Monti, Daniel J. Race, Redevelopment, and the New Company Town. Albany, NY: State University of New York Press, 1990.

Moon, Michael. „,The Gentle Boy from the Dangerous Classes': Pederasty, Domesticity, and Capitalism in Horatio Alger.“ Representations, no. 19 (1987):87-110.

Moore, Jacqueline M. Cow Boys and Cattle Men: Class and Masculinities on the Texas Frontier, 1865-1900. New York: New York University Press, 2010.

Moore, Mark Harrison und Gerstein, Dean R.. Alcohol and Public Policy: Beyond the Shadow of Prohibition. Washington, DC: National Academy Press, 1981.

Moos, Malcolm. The Republicans: A History of Their Party. New York: Random House, 1956.

Morain, Thomas J. Prairie Grass Roots an lowa Small Town in the Early Twentieth Century. Ames: lowa State University Press, 1988.

Morais, Herbert M. und Cahn, William. Gene Debs: The Story of a Fighting American. New York: International Publishers, 1980.

Moran, Richard. Executioner's Current: Thomas Edison, George Westinghouse, and the Invention of the Electric Chair. New York: A.A. Knopf, 2002.

Moreton-Robinson, Aileen, Casey, Maryrose und Nicoll, Fiona Jean. Transnational Whiteness Matters. Lanham, MD: Lexington Books, 2008.

Morgan, H. Wayne. From Hayes to McKinley: National Party Politics, 1877-1896. Syracuse, NY: Syracuse University Press, 1969.

Morris, Charles R. The Tycoons: How Andrew Carnegie, John D. Rockefeller, Jay Gould, and J.P. Morgan Invented the American Supereconomy. New York: H. Holt and Co, 2005.

Morris, James M. und Patricia M. Kearns. Historical Dictionary of the United States Navy. Lanham, MD: Scarecrow Press, 2011.

Morris, Lloyd R. Incredible New York. New York: Arno Press, 1975.

Morris, Patricia McGrath. „An Evaluation of the Nutritional Quality of Meals Served in Soup Kitchens in New York State and an Examination of the Factors That Determine Quality.“ Dissertation, Cornell University, 1988. 
Morris, Roy. Fraud of the Century: Rutherford B. Hayes, Samuel Tilden, and the Stolen Election of 1876. New York: Simon \& Schuster, 2003.

Morris, Thomas D. Southern Slavery and the Law, 1619-1860. Chapel Hill: University of North Carolina Press, 1996.

Morse, Kathryn Taylor. The Nature of Gold: An Environmental History of the Klondike Gold Rush. Seattle: University of Washington Press, 2003.

Moser, John E. Twisting the Lion's Tail: American Anglophobia between the World Wars. New York: New York University Press, 1999.

Most, Doug. The Race Underground: Boston, New York, and the Incredible Rivalry That Built America's First Subway. New York: St. Martin's Press, 2014.

Mozingo, Louise A. Pastoral Capitalism: A History of Suburban Corporate Landscapes. Cambridge, MA: MIT Press, 2011.

Mugridge, Ian. The View from Xanadu: William Randolph Hearst and United States Foreign Policy. Montreal, Buffalo: McGill-Queen's University Press, 1995.

Müller-Pohl, Simone. „The Class of 1866 and the Wiring of the World: Telegraphic Networks in Maritime Space, 1858-1914.“ Dissertation, Freie Universität Berlin, 2012.

Mulrooney, Margaret M., Historic American Buildings Survey, Historic American Engineering Record und America's Industrial Heritage Project. A Legacy of Coal the Coal Company Towns of Southwestern Pennsylvania. Washington, DC: Historic American Buildings Survey, Historic American Engineering Record, National Park Service, 1989.

Munden, Christopher P. „Jay Cooke: Banks, Railroads, and the Panic of 1873.“ Pennsylvania Legacies 11, no. 1 (2011):3-5.

Murphy, Gretchen. Hemispheric Imaginings: The Monroe Doctrine and Narratives of U.S. Empire. Durham, NC: Duke University Press, 2005.

Murphy, John. The Telephone: Wiring America. New York: Chelsea House Publishers, 2009.

Murray, Robert K. Red Scare: A Study in National Hysteria, 1919-1920. Westport, CT: Greenwood Press, 1980.

Mushkat, Jerome. Fernando Wood: A Political Biography. Kent, OH: Kent State University Press, 1990.

Musser, Joe. The Cereal Tycoon: Henry Parsons Crowell, Founder of the Quaker Oats Co. A Biography. Chicago, IL: Moody Press, 1997.

Mutch, Robert E. Buying the Vote: A History of Campaign Finance Reform. Oxford, New York: Oxford University Press, 2014.

Muthyala, John. Dwelling in American: Dissent, Empire, and Globalization. Hanover, NH: Dartmouth College Press, 2012.

Muzzey, David Saville. James G. Blaine a Political Idol of Other Days. Port Washington, NY: Kennikat Press, 1963.

Myers, Gustavus. The History of Tammany Hall. New York: Boni \& Liveright, Inc, 1917.

Myers, Walter Dean und Bonnie Christensen. Ida B. Wells: Let the Truth Be Told. New York: Amistad/Collins, 2008.

Münnix, Gabriele. „Anything Goes? Zum Schlagwort von der postmodernen Beliebigkeit.“ In: André Schütte (Hg.). Freiheit, Moral, Beliebigkeit: Was sollen wir tun? Rheinbach: CMZ-Verlag, 2013, S. 43-72.

Nabers, Deak. Victory of Law: The Fourteenth Amendment, the Civil War, and American Literature, 1852-1867. Baltimore, MD: Johns Hopkins University Press, 2006. 
Nackenoff, Carol. The Fictional Republic: Horatio Alger and American Political Discourse. New York: Oxford University Press, 1994.

Nagel, Joane. American Indian Ethnic Renewal: Red Power and the Resurgence of Identity and Culture. New York: Oxford University Press, 1996.

Nasaw, David. Andrew Carnegie. New York: Penguin Press, 2006.

Nasaw, David. The Chief: The Life of William Randolph Hearst. Boston, MA: Houghton Mifflin, 2000.

Nasaw, David. Going Out: The Rise and Fall of Public Amusements. New York, NY: BasicBooks, 1993.

National Archives and Founders Online. „John Paul Jones to the Commissioners, 9 December 1778.“ [Web Page]: http://founders.archives.gov/?q=\%22Imperial\%20Republic\%22\&s= 1511311111\&r=1. Gesehen am 28.6.2016.

National Bureau of Economic Research. Output, Employment and Productivity in the United States after 1800. New York: National Bureau of Economic Research, 1966.

National Research Council (U.S.) und Committee on the Future of the Colleges of Agriculture in the Land Grant University System. Colleges of Agriculture at the Land Grant Universities: Public Service and Public Policy. Washington, DC: National Academy Press, 1996.

Nealon, Jeffrey T. Post-Postmodernism, or, The Cultural Logic of Just-in-Time Capitalism. Stanford, CA: Stanford University Press, 2012.

Nelson, Bruce. Divided We Stand: American Workers and the Struggle for Black Equality. Princeton, NJ: Princeton University Press, 2001.

Nelson, Lewis B. History of the U.S. Fertilizer Industry. Muscle Shoals, AL: Tennessee Valley Authority, 1990.

Nelson, Megan Kate. Ruin Nation: Destruction and the American Civil War. Athens, GA: University of Georgia Press, 2012.

Nelson, Scott Reynolds. A Nation of Deadbeats: An Uncommon History of America's Financial Disasters. New York: Alfred A. Knopf, 2012.

Nelson, Scott Reynolds. „A Storm of Cheap Goods: New American Commodities and the Panic of 1873.“ The Journal of the Gilded Age and Progressive Era 10, no. 4 (2011):447-453.

Nelson, Scott Reynolds und Carol Sheriff. A People at War Civilians and Soldiers in America's Civil War, 1854-1877. New York: Oxford University Press, 2007.

Nerburn, Kent. Chief Joseph \& the Flight of the Nez Perce the Untold Story of an American Tragedy. New York, NY: HarperCollins, 2005.

Nesbit, Robert C. und Thompson, William Fletcher. Wisconsin: A History. Madison, WI: University of Wisconsin Press, 1989.

Netz, Reviel. Barbed Wire: An Ecology of Modernity. Middletown, CT: Wesleyan University Press, 2004.

Neu, Charles E. An Uncertain Friendship: Theodore Roosevelt and Japan, 1906-1909. Cambridge, MA: Harvard University Press, 1967.

Neumann, Gerson Roberto. Brasilien ist nicht weit von hier! Die Thematik der deutschen Auswanderung nach Brasilien in der deutschen Literatur im 19. Jahrhundert (1800-1871). Frankfurt am Main, New York: P. Lang, 2005.

Nevels, Cynthia Skove. Lynching to Belong: Claiming Whiteness through Racial Violence. College Station, TX: Texas A\&M University Press, 2007.

Nevins, Allan. Grover Cleveland: A Study in Courage. Norwalk, CT: Easton Press, 1989. 
Nevins, Allan. Henry White: Thirty Years of American Diplomacy. New York, London: Harper \& Brothers, 1930.

Newfield, Christopher. Ivy and Industry: Business and the Making of the American University, 1880-1980. Durham, NC: Duke University Press, 2003.

Newsom, Kevin Christopher. „Setting Incorporationism Straight: A Reinterpretation of the Slaughter-House Cases.“ The Yale Law Journal 109, no. 4 (2000):643-744.

Newton, Michael. The Ku Klux Klan in Mississippi: A History. Jefferson, NC: McFarland \& Co, 2010.

Nichols, Christopher McKnight. Promise and Peril: America at the Dawn of a Global Age. Cambridge, MA: Harvard University Press, 2011.

Nielsen, Kim E. Un-American Womanhood: Antiradicalism, Antifeminism, and the First Red Scare. Columbus, OH: Ohio State University Press, 2001.

Nieman, Donald G. From Slavery to Sharecropping: White Land and Black Labor in the Rural South, 1865-1900. New York: Garland, 1994.

Ninkovich, Frank A. The United States and Imperialism. Malden, MA: Blackwell Publishers, 2001.

Ninkovich, Frank A. The Wilsonian Century: U.S. Foreign Policy since 1900. Chicago, IL: University of Chicago Press, 1999.

Norgren, Jill. Belva Lockwood: Equal Rights Pioneer. Minneapolis, MN: Twenty-First Century Books, 2009.

Norgren, Jill. Belva Lockwood: The Woman Who Would Be President. New York, London: New York University Press, 2007.

North, Douglass C. The Economic Growth of the United States, 1790-1860. Englewood Cliffs, NJ: Prentice-Hall, 1961.

Northrup, Cynthia Clark und Prange Turney, Elaine C.. Encyclopedia of Tariffs and Trade in U.S. History. Westport, CT: Greenwood Press, 2003.

Northrup, Cynthia L. Clark. The American Economy: A Historical Encyclopedia. Santa Barbara, CA: ABC-CLIO, 2011.

Norton, Mary Beth. „,Either Married or Bee Married': Women's Legal Equality in Early America." In: Pestana, Carla Gardina und Sharon V. Salinger (Hg.). Inequality in Early America. Hanover, NH: University Press of New England, 1999, S. 25-45.

Nugent, Walter T. K. Progressivism: A Very Short Introduction. Oxford, New York: Oxford University Press, 2010.

Nugent, Walter T. The Tolerant Populists: Kansas Populism and Nativism. Chicago, IL: Universiy of Chicago Press, 2013.

Numbers, Ronald L. und Stenhouse, John. Disseminating Darwinism: The Role of Place, Race, Religion, and Gender. Cambridge England, New York: Cambridge University Press, 1999.

Nutter, Kathleen Banks. The Necessity of Organization: Mary Kenney O'Sullivan and Trade Unionism for Women, 1892-1912. New York: Garland Pub, 2000.

Nye, David E. Consuming Power: A Social History of American Energies. Cambridge, MA: MIT Press, 1998.

Nye, Joseph S. The Paradox of American Power: Why the World's Only Superpower Can't Go It Alone. Oxford, New York: Oxford University Press, 2002.

Nye, Joseph S. „Power and Interdependence Revisited.“ International Organization. 1987, 41(4):725-753. 
Nye, Joseph S. Soft Power: The Means to Success in World Politics. New York: Public Affairs, 2004.

Nye, Joseph S. „The Velvet Hegemon.“ Foreign Policy 136 (2003):74-75.

Nye, Joseph S. „The Dependent Colossus.“ Foreign Policy. 2002, (129):74-76.

Nye, Joseph S. „The Future of American Power: Dominance and Decline in Perspective.“ Foreign Affairs. 2010, 89(6):2-12.

O’Brien, Sharon. American Indian Tribal Governments. Norman, OK: University of Oklahoma Press, 1989.

O'Brien, Thomas F. The Century of U.S. Capitalism in Latin America. Albuquerque: University of New Mexico Press, 1999.

O'Connell, Kevin. Tom Johnson: The Life and Times of Cleveland's Greatest Mayor. Cleveland, Ohio: Green Road Press, 2001.

O'Connell, Robert L. Sacred Vessels: The Cult of the Battleship and the Rise of the U.S. Navy. New York: Oxford University Press, 1993.

O’Foran, Shelly. Little Zion: A Church Baptized by Fire. Chapel Hill, NC: University of North Carolina Press, 2006.

O'Leary, Brendan. The Asiatic Mode of Production: Oriental Despotism, Historical Materialism, and Indian History. Oxford, Cambridge, MA: B. Blackwell, 1989.

Oates, Stephen B. Our Fiery Trial Abraham Lincoln, John Brown, and the Civil War Era. Amherst: University of Massachusetts Press, 1979.

Ochiai, Akiko. „The Port Royal Experiment Revisited: Northern Visions of Reconstruction and the Land Question.“ The New England Quarterly 74, no. 1 (2001):94-117.

Offner, John L. An Unwanted War: The Diplomacy of the United States and Spain over Cuba, 1895-1898. Chapel Hill, NC: University of North Carolina Press, 1992.

Ohrem, Dominik. „,American Knights in Buckskin‘: Das Männlichkeitsdispositiv der Frontier und Narrative der Nationsbildung in den USA des 19. und frühen 20. Jahrhunderts.“ In: Elke Kleinau, Dirk Schulz und Susanne Völker (Hg.). Gender in Bewegung: Aktuelle Spannungsfelder der Gender und Queer Studies. Bielefeld: transcript, 2013, S. 289-306.

Oleinik, Anton. Market as a Weapon: The Socio-Economic Machinery of Dominance in Russia. New Brunswick, NJ: Transaction Publishers, 2010

Olien, Roger M. und Davids Hinton, Diana. Oil and Ideology: The Cultural Creation of the American Petroleum Industry. Chapel Hill, NC: University of North Carolina Press, 2000.

Olson, Lynne. Freedom's Daughters: The Unsung Heroines of the Civil Rights Movement from 1830 to 1970. New York: Scribner, 2001.

Onuf, Peter S. Jefferson's Empire: The Language of American Nationhood. Charlottesville, VA: University Press of Virginia, 2000.

Oppenheimer, Joe A. Principles of Politics: A Rational Choice Theory Guide to Politics and Social Justice. Cambridge, New York: Cambridge University Press, 2012.

Organisation of American Historians. The LaPietra Report: A Report to the Profession [Web Page]:

http://www.oah.org/about/reports/reports-statements/the-lapietra-report-a-report-to-the-profession/. Gesehen am 30. November 2016.

Orlemann, Eric C. Caterpillar. St. Paul, MN: Motorbooks, 2006.

Osterhammel, Jürgen. Die Verwandlung der Welt: Eine Geschichte des 19. Jahrhunderts. München: Beck, 2009. 
Osterhammel, Jürgen. The Transformation of the World: A Global History of the Nineteenth Century. Princeton, NJ: Princeton University Press, 2014.

Osterhammel, Jürgen und Petersson, Niels P. Globalization: A Short History. Princeton, N): Princeton University Press, 2005.

Osthaus, Carl R. Freedmen, Philanthropy, and Fraud: A History of the Freedman's Savings Bank. Urbana, IL: University of Illinois Press, 1976.

Ostler, Jeffrey. Prairie Populism: The Fate of Agrarian Radicalism in Kansas, Nebraska, and lowa, 1880-1892. Lawrence, KS: University Press of Kansas, 1993.

Ostler, Jeffrey. „Why the Populist Party Was Strong in Kansas and Nebraska but Weak in lowa.“ The Western Historical Quarterly 23, no. 4 (1992):451- 474.

Ostrogorski, Moissei Jakowlewitsch. Democracy and the Organization of Political Parties. New York: Haskell House Publishers, 1970, 2 Bände.

Otfinoski, Steven. Chester Arthur. Tarrytown, NY: Marshall Cavendish Benchmark, 2010.

Otis, D. S., Prucha, Francis Paul , United States, Congress, House und Committee on Indian Affairs. The Dawes Act and the Allotment of Indian Lands. Norman, OK: University of Oklahoma Press, 1973.

Oubre, Claude F. Forty Acres and a Mule: The Freedmen's Bureau and Black Land Ownership. Baton Rouge, LA: Louisiana State University Press, 1978.

Oubre, Claude F. „,Forty Acres and a Mule': Louisiana and the Southern Homestead Act.“ Louisiana History: The Journal of the Louisiana Historical Association. 1976, 17 (2):143-157.

Oulton, Nicholas. Chain Indices of the Cost of Living and the Path-Dependence Problem. London: Centre for Economic Performance, London School of Economics and Political Science, 2007.

Outhwaite, William. Europe since 1989: Transitions and Transformations. London, New York: Routledge, 2015.

Overmyer-Velázquez, Mark. Beyond la Frontera: The History of Mexico-U.S. Migration. New York: Oxford University Press, 2011.

Owen, Thomas C. Dilemmas of Russian Capitalism: Fedor Chizhov and Corporate Enterprise in the Railroad Age. Cambridge, MA: Harvard University Press, 2005.

Paine, Albert Bigelow. Mark Twain: A Biography. The Personal and Literary Life of Samuel Langhorne Clemens. New York, London: Harper, 1935.

Painter, Nell Irvin. Standing at Armageddon: The United States, 1877-1919. New York: W.W. Norton, 1987.

Pak, Susie. Gentlemen Bankers: The World of J.P. Morgan. Cambridge, MA: Harvard University Press, 2013.

Palen, Marc-William. „The Imperialism of Economic Nationalism, 1890-1913.“ Diplomatic History 39, no. 1 (2015):157-85.

Palen, Marc-William. „Protection, Federation, and Union: The Global Impact of the McKinley Tariff upon the British Empire, 1890-1894.“ Journal of Imperial and Commonwealth History 38, no. 3 (2010):395- 418.

Palier, Bruno und Bonoli, Guiliano. „Phénomènes de ,Path Dependence“ et Réformes des Systèmes de Protection Sociale“. Revue Française de Science Politique. 1999, 49 (3):399- 420.

Palladino, Paolo. Entomology, Ecology, and Agriculture: The Making of Scientific Careers in North America, 1885 -1985. Amsterdam: Harwood Academic Publishers, 1996. 
Palmer, Jessica Dawn. The Dakota Peoples: A History of the Dakota, Lakota and Nakota through 1863. Jefferson, NC: McFarland \& Co, 2008.

Palmer, Phyllis M. Domesticity and Dirt: Housewives and Domestic Servants in the United States, 1920-1945. Philadelphia, PA: Temple University Press, 1989.

Papke, David Ray. Heretics in the Temple: Americans Who Reject the Nation's Legal Faith. New York: New York University Press, 1998.

Papke, David Ray. The Pullman Case: The Clash of Labor and Capital in Industrial America. Lawrence, KS: University Press of Kansas, 1999.

Parker, Geoffrey und Philip E. Tetlock. „Counterfactual History: Its Advocates, Its Critics, \& Its Uses.“ In: Philip E. Tetlock, Richard Ned Lebow und Geoffrey Parker. Unmaking the West: „What-If“ Scenarios That Rewrite World History.Ann Arbor, MI: University of Michigan Press, 2006., S. 363-392.

Parker, Marjorie H. „Some Educational Activities of the Freedmen's Bureau.“ The Journal of Negro Education 23, no. 1 (1954):9-21.

Parker, Matthew. Panama Fever: The Epic Story of One of the Greatest Achievements of All Time - the Building of the Panama Canal. New York: Doubleday, 2007.

Parrini, Carl P. und Sklar, Martin J. „New Thinking about the Market, 1896-1904: Some American Economists on Investment and the Theory of Surplus Capital." The Journal of Economic History 43, no. 3 (1983):559-78.

Pascoe, Peggy. Relations of Rescue: The Search for Female Moral Authority in the American West, 1874 -1939. New York: Oxford University Press, 1990.

Passavant, Paul A. und Dean, Jodi. Empire's New Clothes: Reading Hardt and Negri. New York: Routledge, 2004.

Paterson, Thomas G. Contesting Castro: The United States and the Triumph of the Cuban Revolution. New York: Oxford University Press, 1994.

Patel, Kiran Klaus. Nach der Nationalfixiertheit: Perspektiven einer transnationalen Geschichte. Berlin: Humboldt Universität, 2004.

Patel, Kiran Klaus. „,Transnations’ among ,Transnations’? The Debate on Transnational History in the United States and Germany. “ Amerikastudien / American Studies. 2009, 54 (3):451- 472.

Pattie, Frank A. Mesmer and Animal Magnetism: A Chapter in the History of Medicine. Hamilton, NY: Edmonston Pub, 1994.

Paul, Ron. End the Fed. New York: Grand Central Pub, 2009.

Paulet, Elisabeth. The Role of Banks in Monitoring Firms: The Case of the Crédit Mobilier. London, New York: Routledge, 1999.

Paulinyi, Ákos. Das Puddeln: Ein Kapitel aus der Geschichte des Eisens in der industriellen Revolution. München: Oldenbourg, 1987.

Paxson, Frederic L. The Last American Frontier. New York: Macmillan, 1910.

Payne, Walter A. (Hg.). Benjamin Holt: The Story of the Caterpillar Tractor. Stockton, CA: University of the Pacific, 1982.

Pease, Donald E. The New American Exceptionalism. Minneapolis: University of Minnesota Press, 2009.

Peden, Henry C. und Shagena, Jack L. . The Ma \& Pa Remembered: A History of the Maryland \& Pennsylvania Railroad. Bel Air, MD: Privately printed by the Authors, 2011.

Pennington, Jack L. The Battle of the Little Bighorn: A Comprehensive Study. El Segundo, CA: Upton \& Sons, 2001. 
Pérez, Louis A. Cuba and the United States: Ties of Singular Intimacy. Athens, GA: University of Georgia Press, 2003.

Pérez, Louis A. The War of 1898: The United States and Cuba in History and Historiography. Chapel Hill, NC: University of North Carolina Press, 1998.

Perdue, Theda und Green, Michael D. The Cherokee Nation and the Trail of Tears. New York: Viking, 2007.

Perman, Michael. Emancipation and Reconstruction, 1862-1879. Arlington Heights, IL: Harlan Davidson, 1987.

Perman, Michael. The Road to Redemption: Southern Politics, 1869-1879. Chapel Hill, NC: University of North Carolina Press, 1984.

Perret, Geoffrey. Ulysses S. Grant: Soldier \& President. New York: Modern Library, 1999.

Peskin, Allan. Garfield: A Biography. Kent, OH: Kent State University Press, 1999.

Peskin, Allan. „Was There a Compromise of 1877?“ The Journal of American History 60, no. 1 (1973):63-75.

Peskin, Allan. „Who Were the Stalwarts? Who Were Their Rivals? Republican Factions in the Gilded Age.“ Political Science Quarterly 99, no. 4 (1984-1985):703-716.

Pestana, Carla Gardina und Salinger, Sharon V.. Inequality in Early America. Hanover, NH: University Press of New England, 1999.

Pestritto, Ronald J. und Atto, William J.. American Progressivism a Reader. Lanham, MD: Lexington Books, 2008.

Pfannestiel, Todd J. Rethinking the Red Scare: The Lusk Committee and New York's Crusade against Radicalism, 1919-1923. New York: Routledge, 2003.

Phelan, Craig. Grand Master Workman: Terence Powderly and the Knights of Labor. Westport, CT: Greenwood Press, 2000.

Phillips, Dennis. „The Tragedy of American Diplomacy: A Tribute to the Legacy of William Appleman Williams." Australasian Journal of American Studies 2007, 26 (2):89-98.

Phillips, Kevin. William McKinley. New York: Times Books, 2003.

Phipps, Stanley S. From Bull Pen to Bargaining Table: The Tumultuous Struggle of the Coeur D’Alenes Miners for the Right to Organize, 1887-1942. New York: Garland, 1988.

Pierson, Paul. Politics in Time: History, Institutions, and Social Analysis. Princeton, NJ: Princeton University Press, 2004.

Piott, Steven L. American Reformers, 1870-1920: Progressives in Word and Deed. Lanham, MD: Rowman \& Littlefield Publishers, 2006.

Piott, Steven L. Daily Life in the Progressive Era. Santa Barbara, CA: Greenwood, 2011.

Pisani, Donald J. From the Family Farm to Agribusiness: The Irrigation Crusade in California and the West, 1850-1931. Berkeley, CA: University of California Press, 1984.

Pisani, Donald J. To Reclaim a Divided West: Water, Law, and Public Policy, 1848-1902. Albuquerque, NM: University of New Mexico Press, 1992.

Pisani, Donald J. Water and American Government: The Reclamation Bureau, National Water Policy, and the West, 1902-1935. Berkeley, CA: University of California Press, 2002.

Pisani, Donald J. Water, Land, and Law in the West: The Limits of Public Policy, 1850-1920. Lawrence, KS: University Press of Kansas, 1996.

Pitsula, James Michael. Keeping Canada British: The Ku Klux Klan in 1920s Saskatchewan. Vancouver, BC: UBC Press, 2013.

Pizer, Russell A. The Tangled Web of Patent \#174,465. Bloomington, IN: Authorhouse, 2009. 
Pletcher, David M. Mexico Opens the Door to American Capital, 1877-1880. The Americas. 1959, 16 (1):1-14.

Poliakov, Léon. The History of Anti-Semitism. London: Routledge \& Kegan Paul, 1974-1985.

Pollack, Norman. The Just Polity: Populism, Law, and Human Welfare. Urbana, IL: University of Illinois Press, 1987.

Pollack, Norman. The Populist Mind. Indianapolis, IN: Bobbs-Merrill, 1967.

Pollack, Norman. The Populist Response to Industrial America: Midwestern Populist Thought. Cambridge, MA: Harvard University Press, 1962.

Polyné, Millery. From Douglass to Duvalier: U.S. African Americans, Haiti, and Pan Americanism, 1870-1964. Gainesville, FL: University Press of Florida, 2010.

Polyné, Millery. „Expansion Now!: Haiti, ,Santo Domingo“, and Frederick Douglass at the Intersection of U.S. and Caribbean Pan-Americanism. "Caribbean Studies. 2006, 34 (2):3-45.

Pommersheim, Frank. Broken Landscape: Indians, Indian Tribes, and the Constitution. Oxford, New York: Oxford University Press, 2009.

Ponso, Marzia. Una Storia Particolare: „Sonderweg“ Tedesco e Identita Europea. Bologna: Il mulino, 2011.

Poole, Keith T. und Rosenthal, Howard. Ideology \& Congress. New Brusnwick, NJ: Transaction Publishers, 2007.

Pope, Steven W. Patriotic Games: Sporting Traditions in the American Imagination, 1876-1926. Knoxville, TN: University of Tennessee Press, 2007.

Porterfield, Jason. The Homestead Act of 1862: A Primary Source History of the Settlement of the American Heartland in the Late 19th Century. New York: Rosen Pub. Group, 2005.

Postel, Charles. The Populist Vision. Oxford, New York: Oxford University Press, 2007.

Potter, David Morris. Division and the Stresses of Reunion, 1845-1876. Glenview, IL: Scott, Foresman, 1973.

Powell, John. Encyclopedia of North American Immigration. New York: Facts on File, 2005.

Powers, Thomas. The Killing of Crazy Horse. New York: Alfred A. Knopf, 2010.

Prager, Robin A. „Using Stock Price Data to Measure the Effects of Regulation: The Interstate Commerce Act and the Railroad Industry.“ The RAND Journal of Economics 20, no. 2 (1989): $280-290$.

Pratt, Julius William. Challenge and Rejection: The United States and World Leadership, 1900 -1921. New York: Macmillan, 1967.

Pratt, Julius William. A History of United States Foreign Policy. Englewood Cliffs, NJ: Prentice-Hall, 1965.

Preston, Samuel H. und Haines, Michael R.. Fatal Years: Child Mortality in Late Nineteenth-Century America. Princeton, NJ: Princeton University Press, 1991.

Price, Jay M. Cherokee Strip Land Rush. Charleston, SC: Arcadia Pub, 2006.

Pries, Ludger. Die Transnationalisierung der sozialen Welt: Sozialräume jenseits von Nationalgesellschaften. Frankfurt am Main: Suhrkamp, 2008.

Prince, K. Stephen. Stories of the South: Race and the Reconstruction of Southern Identity, 1865-1915. Chapel Hill, NC: University of North Carolina Press, 2014.

Pringle, Henry F. Theodore Roosevelt: A Biography. New York: Blue ribbon books, 1931.

Promey, Sally M. Painting Religion in Public: John Singer Sargent's Triumph of Religion at the Boston Public Library. Princeton, NJ: Princeton University Press, 1999.

Purcell, L. Edward. Vice Presidents: A Biographical Dictionary. New York: Facts On File, 2010. 
Quatannens, Jo Anne McCormick und Boyle, Diane B. Senators of the United States:

A Historical Bibliography. A Compilation of Works by and About Members of the United

States Senate, 1789-1995. Washington, DC: Government Printing Office, 1995.

Quigley, Paul. Shifting Grounds Nationalism and the American South, 1848-1865. New York: Oxford University Press, 2011.

Quint, Howard H. „American Socialists and the Spanish-American War.“ American

Quarterly 10, no. 2 (1958):131- 41.

Raat, W. Dirk und Beezley, William H.. Twentieth-Century Mexico. Lincoln, NE: University of Nebraska Press, 1986.

Raban, Jonathan. Bad Land: An American Romance. New York: Pantheon Books, 1996.

Rabinowitz, Howard N. Southern Black Leaders of the Reconstruction Era. Urbana, IL: University of Illinois Press, 1982.

Rable, George C. But There Was No Peace: The Role of Violence in the Politics of Reconstruction. Athens, GA: University of Georgia Press, 2007.

Rachal, John R. „Gideonites and Freedmen: Adult Literacy Education at Port Royal, 1862 -1865.“ The Journal of Negro Education 55, no. 4 (1986):453- 469.

Rankin, David C. „The Origins of Negro Leadership in New Orleans during Reconstruction.“ In: Howard N. Rabinowitz (Hg.). Southern Black Leaders of the Reconstruction Era. Urbana IL: University of Chicago Press, 1982, S. 155-190.

Ransom, Roger L. und Sutch. Richard. One Kind of Freedom: The Economic Consequences of Emancipation. Cambridge, New York: Cambridge University Press, 2001.

Raphael, Lutz. Jenseits von Strukturwandel oder Ereignis? Neuere Sichtweisen und Schwierigkeiten der Historiker im Umgang mit Wandel und Innovation. Historische Anthropologie. 2009, 17 (1):110-120.

Rapport, Sara. „The Freedmen's Bureau as a Legal Agent for Black Men and Women in Georgia: 1865-1868.“ The Georgia Historical Quarterly 73, no. 1 (1989):26-53.

Rauchway, Eric. The Refuge of Affections: Family and American Reform Politics, 1900-1920. New York: Columbia University Press, 2001.

Raulet, Gérard. Historismus, Sonderweg und dritte Wege. Frankfurt am Main, New York: P. Lang, 2001.

Rauschenbusch, Walter. The Social Principles of Jesus. Folcroft, PA: Folcroft Library Editions, 1976.

Rayback, Joseph G. A History of American Labor. New York: Free Press, 1966.

Rea, Tom. Bone Wars: The Excavation and Celebrity of Andrew Carnegie's Dinosaur. Pittsburgh, PA: University of Pittsburgh Press, 2001.

Reed, Christopher Robert. Knock at the Door of Opportunity: Black Migration to Chicago, 1900 -1919. Carbondale, IL: Southern Illinois University Press, 2014.

Reef, Catherine. Working in America. New York: Facts on File, 2007.

Rehnquist, William H. Centennial Crisis: The Disputed Election of 1876. New York: Alfred A. Knopf. Distributed by Random House, 2004.

Reich, Leonard S. The Making of American Industrial Research Science and Business at GE and Bell, 1876-1926. Cambridge, New York: Cambridge University Press, 1985.

Reick, Philipp. „Labor is Not a Commodity“: Contested Working Class Discourse and the Movement to Shorten the Workday in Berlin and New York City in the Late 1860s and Early 1870s. Dissertation, Berlin: Freie Universität, 2015. 
Reid, Debra Ann und Bennett, Evan P. (Hg.). Beyond Forty Acres and a Mule: African American Landowning Families since Reconstruction. Gainesville, FL: University Press of Florida, 2012.

Reinhardt, Stefan. Die Darstellung der Revolution von 1848/49 in den Lebenserinnerungen von Carl Schurz und Otto von Corvin. Frankfurt am Main, New York: P. Lang, 1999.

Renehan, Edward. The Monroe Doctrine: The Cornerstone of American Foreign Policy. New York: Chelsea House, 2007.

Renehan, Edward. Commodore: The Life of Cornelius Vanderbilt. New York: Basic Books, 2007.

Renehan, Edward. Dark Genius of Wall Street: The Misunderstood Life of Jay Gould, King of the Robber Barons. New York: Basic Books, 2005.

Renshaw, Patrick. The Wobblies: The Story of the IWW and Syndicalism in the United States. Chicago, IL: Ivan R. Dee, 1999.

Resende-Santos, João. Neorealism, States, and the Modern Mass Army. New York: Cambridge University Press, 2007.

Restad, Hilde Eliassen. „Old Paradigms in History Die Hard in Political Science: US Foreign Policy and American Exceptionalism.“ American Political Thought 1, no. 1 (2012):53-76.

Rezneck, Samuel. „Unemployment, Unrest, and Relief in the United States during the Depression of 1893-97.“ Journal of Political Economy. 1953, 61 (4):323-345.

Richardson, Darcy G. Others: Third-Party Politics from the Nation's Founding to the Rise and Fall of the Greenback-Labor Party. New York: IUniverse, Inc., 2004.

Richardson, Heather Cox. The Death of Reconstruction: Race, Labor, and Politics in the Post-Civil War North, 1865-1901. Cambridge, MA: Harvard University Press, 2001.

Richardson, Joe M. „An Evaluation of the Freedmen's Bureau in Florida.“ The Florida Historical Quarterly 41, no. 3 (1963):223-238.

Rickover, Hyman G. How the Battleship Maine Was Destroyed. Washington, DC: Government Printing Office, 1976.

Rimlinger, Gaston V. „Labor and the Government: A Comparative Historical Perspective.“ The Journal of Economic History. 1977, 37 (1):210 - 225.

Ritter, Gretchen. Goldbugs and Greenbacks: The Antimonopoly Tradition and the Politics of Finance in America. Cambridge, New York: Cambridge University Press, 1997.

Rixen, Thomas, Viola, Lora Anne und Zürn, Michael. Historical Institutionalism and International Relations: Explaining Institutional Development in World Politics. Oxford, New York: Oxford University Press, 2016.

Roark, James L. Masters without Slaves: Southern Planters in the Civil War and Reconstruction. New York: Norton, 1977.

Roberts, B. W. C. und Roberts, Snow L.. Bull Durham: Business Bonanza, 1866-1940. Durham, NC: Genuine Durham Press, 2002.

Roberts, Giselle. The Confederate Belle. Columbia: University of Missouri Press, 2003.

Roberts, Robert North, Hammond, Scott J. und Sulfaro, Valerie A.. Presidential Campaigns, Slogans, Issues, and Platforms: The Complete Encyclopedia. Santa Barbara, CA: Greenwood, 2012.

Robertson, Angelique. Women Who Did: Stories by Men and Women, 1890-1914. London: Penguin, 2005.

Robertson, David Brian. Capital, Labor, and State: The Battle for American Labor Markets from the Civil War to the New Deal. Lanham, MD: Rowman \& Littlefield Publishers, 2000. 
Rodgers, Daniel T. Atlantic Crossings: Social Politics in a Progressive Age. Cambridge, MA: Belknap Press of Harvard University Press, 1998.

Rodriguez, Gregory. Mongrels, Bastards, Orphans, and Vagabonds: Mexican Immigration and the Future of Race in America. New York: Vintage Books, 2008.

Roediger, David R. „America’s First General Strike: The St. Louis ,Commune‘ of 1877.“ Midwest Quarterly 21 (1989-1990):196-206.

Roediger, David R. Working toward Whiteness: How America's Immigrants Became White. The Strange Journey from Ellis Island to the Suburbs. New York: Basic Books, 2005.

Roediger, David R. und Foner, Philip Sheldon. Our Own Time: A History of American Labor and the Working Day. London, New York: Verso, 1989.

Roger-Cooper, Justin. „Blood or Bread: The 1877 General Strike and Anglophone Food Riots.“ [Web Page]: https://www.academia.edu/2997605/2012_ASA_Conference_Paper_on_1877_ General_Strike. Gesehen am 13.7.2013.

Rogers, Jerry R. Civil Engineering History: Engineers Make History. Proceedings of the First National Symposium on Civil Engineering History. New York: American Society of Civil Engineers, 1996.

Rogers, Jerry R. Engineering History and Heritage: Proceedings of the Second National Congress on Civil Engineering History and Heritage. Reston, VA: American Society of Civil Engineers, 1998.

Rogers, Jerry R. International Engineering History and Heritage: Improving Bridges to ASCE's 150th Anniversary. Proceedings of the Third National Congress on Civil Engineering History and Heritage, October 10-13, 2001, Houston, Texas. Reston, VA: American Society of Civil Engineers, 2001.

Rohlfing, Helmut. „John Pierpont Morgan als Förderer der Göttinger Universitätsbibliothek.“ In: Kelleter, Frank und Knöbl, Wolfgang (Hg.). Amerika und Deutschland: Ambivalente Begegnungen. Göttingen: Wallstein, 2006, S. 242-248.

Roithmayr, Daria. Reproducing Racism: How Everyday Choices Lock In White Advantage. New York: New York University Press, 2014.

Romer, Christina. „Spurious Volatility in Historical Unemployment Data.“ Journal of Political Economy 94, no. 1 (1986):1-37.

Roosevelt, Theodore. The Rough Riders. New York: Barnes \& Noble Books, 2004.

Rose, J. Holland, Newton, Arthur Percival, Benians, E. A. und Dodwell, Henry. The Cambridge History of the British Empire. Cambridge: Cambridge University Press, 1929-1959.

Rose, James Douglas. Duquesne and the Rise of Steel Unionism. Urbana, IL: University of Illinois Press, 2001.

Rose, Willie Lee Nichols. Rehearsal for Reconstruction: The Port Royal Experiment. Athens, GA: University of Georgia Press, 1999.

Rosen, Jeffrey. The Supreme Court: The Personalities and Rivalries That Defined America. New York: Times Books, 2007.

Rosenberg, Charles E. The Trial of the Assassin Guiteau: Psychiatry and Law in the Gilded Age. Chicago, IL: University of Chicago Press, 1968.

Rosenberg, Daniel. New Orleans Dockworkers: Race, Labor, and Unionism, 1892-1923. Albany, NY: State University of New York Press, 1988.

Rosenberg, Emily S. Transnational Currents in a Shrinking World 1870-1945. Cambridge, MA: Harvard University Press, 2014. 
Rosenberg, Emily S. A World Connecting, 1870-1945. Cambridge, MA: Belknap Press of Harvard University Press, 2012.

Rosenberg, Emily S. und Foner, Eric. Spreading the American Dream: American Economic and Cultural Expansion, 1890-1945. New York: Hill and Wang, 1982.

Rosenbloom, David H. und Emmert, Mark A. Centenary Issues of the Pendleton Act of 1883: The Problematic Legacy of Civil Service Reform. New York: M. Dekker, 1982.

Rosenbloom, Joshua L. Path Dependence and the Origins of the Cotton Textile Manufacturing in New England. In: Farnie, D. A. und Jeremy, David J. (Hg.). The Fibre that Changed the World: The Cotton Industry in International Perspective, 1600-1990s. Oxford, New York: Oxford University Press, 2004, S. 365-394.

Rosenfeld, Gavriel. „Why Do We Ask ,What If?': Reflections on the Function of Alternate History. “ History and Theory. 2002, 41 (4):90-103.

Ross, Jeffrey lan, (Hg.). American Indians at Risk. Santa Barbara, CA: ABC Clio, 2014.

Ross, Michael A. Justice Miller's Reconstruction: The Slaughter-House Cases, Health Codes, and Civil Rights in New Orleans, 1861-1873." The Journal of Southern History 64, no. 4 (1998):649-676.

Ross, Michael A. Justice of Shattered Dreams: Samuel Freeman Miller and the Supreme Court during the Civil War Era. Baton Rouge, LA: Louisiana State University Press, 2003.

Rossum, Ralph A. Federalism, the Supreme Court, and the Seventeenth Amendment: The Irony of Constitutional Democracy. Lanham, Md: Lexington Books, 2001.

Rothman, Sheila M. Woman's Proper Place: A History of Changing Ideals and Practices, 1870 to the Present. New York: Basic Books, 1978.

Royce, Edward Cary. The Origins of Southern Sharecropping. Philadelphia: Temple University Press, 1993.

Royster, Charles. The Destructive War: William Tecumseh Sherman, Stonewall Jackson, and the Americans. New York: Vintage Books, 1993.

Rozema, Vicki. Voices from the Trail of Tears. Winston-Salem, NC: J.F. Blair.

Ruane, Joseph und Todd, Jennifer. „The Roots of Intense Ethnic Conflict May Not in Fact be Ethnic: Categories, Communities and Path Dependence." European Journal of Sociology / Archives Europènnes de Sociologie / Europäisches Archiv für Soziologie. 2004, 45 (2):209- 232.

Rubin, Hyman. South Carolina Scalawags. Columbia, SC: University of South Carolina Press, 2006.

Rugoff, Milton. America's Gilded Age: Intimate Portraits from an Era of Extravagance and Change, 1850-1890. New York: Holt, 1989.

Ruppel, Kristin T. Unearthing Indian Land: Living with the Legacies of Allotment. Tucson, AR: University of Arizona Press, 2008.

Rushdy, Ashraf H. A. American Lynching. New Haven, CT: Yale University Press, 2012.

Russell, Catherine. Experimental Ethnography. Durham, NC: Duke University Press, 1999.

Russell, Francis. The Shadow of Blooming Grove Warren G. Harding in His Times. New York: McGraw-Hill, 1968.

Ruswick, Brent. Almost Worthy: The Poor, Paupers, and the Science of Charity in America, 1877-1917. Bloomington, IN: Indiana University Press, 2013.

Rutkow, Ira M. James A. Garfield. New York: Times Books, 2006.

Ruttan, Vernon W. „Induced Innovation, Evolutionary Theory and Path Dependence: Sources of Technical Change.“ The Economic Journal. 1997, 107 (444):1520-1529. 
Ryan, David. US Foreign Policy in World History. New York: Routledge, 2000.

Rystad, Göran. Ambiguous Imperialism: American Foreign Policy and Domestic Politics at the Turn of the Century. Stockholm: Esselte studium, 1975.

Rüsen, Jörn. Grundzüge einer Historik, 3 Bände. Band 1: Historische Vernunft: Die Grundlagen der Geschichtswissenschaft. Göttingen: Vandenhoeck und Ruprecht, 1983.

Rüsen, Jörn. Grundzüge einer Historik, 3 Bände. Band 2: Rekonstruktion der Vergangenheit: Die Prinzipien der Historischen Forschung. Göttingen: Vandenhoeck und Ruprecht, 1986.

Sachsenmaier, Dominic. Global Perspectives on Global History: Theories and Approaches in a Connected World. Cambridge, New York: Cambridge University Press, 2011.

Saito, Natsu Taylor. Meeting the Enemy: American Exceptionalism and International Law. New York, London: New York University Press, 2010.

Saldern, Adelheid von. Amerikanismus: Kulturelle Abgrenzung von Europa und US-Nationalismus im frühen 20. Jahrhundert. Stuttgart: Franz Steiner Verlag, 2013.

Saller, Carol und Green, Ken. Florence Kelley. Minneapolis, MN: Carolrhoda Books, 1997.

Salvatore, Nick. Eugene V. Debs: Citizen and Socialist. Urbana, IL: University of Illinois Press, 1982.

Samuels, Ernest. Henry Adams. Cambridge, MA: Belknap Press of Harvard University Press, 1989.

Samuels, Peggy und Harold Samuels. Remembering the Maine. Washington, DC: Smithsonian Institution Press, 1995.

Sancton, Thomas A. „The Myth of French Worker Support for the North in the American Civil War.“ French Historical Studies. 1979, 11 (1):58-80.

Sandleben, Guenther. Nationalökonomie und Staat: Zur Kritik der Theorie des Finanzkapitals. Hamburg: VSA, 2003.

Sandmeyer, Elmer Clarence. The Anti-Chinese Movement in California. Urbana, IL: University of Illinois Press, 1991.

Sandoz, Mari. The Buffalo Hunters: The Story of the Hide Men. Lincoln, NE: University of Nebraska Press, 2008.

Sanger, Martha Frick Symington. Henry Clay Frick: An Intimate Portrait. New York: Abbeville Press Publishers, 1998.

Santink, Joy L. Timothy Eaton and the Rise of His Department Store. Toronto, Buffalo: University of Toronto Press, 1990.

Saville, Julie. The Work of Reconstruction from Slave to Wage Laborer in South Carolina, 1860 -1870. Cambridge, New York: Cambridge University Press, 1994.

Sawaya, Francesca. Modern Women, Modern Work: Domesticity, Professionalism, and American Writing, 1890-1950. Philadelphia, PA: University of Pennsylvania Press, 2004.

Sawer, Marian. Marxism and the Question of the Asiatic Mode of Production. The Hague: Nijhoff, 1977.

Saxton, Alexander. „The Army of Canton in the High Sierra.“ The Pacific Historical Review 35, no. 2 (1966):141-152.

Saxton, Alexander. The Indispensable Enemy: Labor and the Anti-Chinese Movement in California. Berkeley, CA: University of California Press, 1995.

Sayre, Laura Browne und Clark, Sean. Fields of Learning: The Student Farm Movement in North America. Lexington, KY: University Press of Kentucky, 2011.

Scaturro, Frank J. The Supreme Court's Retreat from Reconstruction: A Distortion of Constitutional Jurisprudence. Westport, CT: Greenwood Press, 2000 
Scheman, L. Ronald. The Inter-American Dilemma: The Search for Inter-American Cooperation at the Centennial of the Inter-American System. New York: Praeger, 1988.

Schicketanz, Frank Michael. The „Lebenserinnerungen“ of Carl Schurz: A Critical Reading. Konstanz: Hartung Gorre-Verlag, 1987.

Schirmer, Daniel B. Republic or Empire: American Resistance to the Philippine War. Cambridge, MA: Schenkman Pub. Co., distributed by General Learning Press, Morristown, NJ, 1972.

Schisgall, Oscar. Eyes on Tomorrow: The Evolution of Procter \& Gamble. Chicago, IL, New York: J.G. Ferguson Pub. Co. Distributed by Doubleday, 1981.

Schlesinger, Arthur M., Israel, Fred L. und Frent, David J.. The Election of 1876 and the Administration of Rutherford B. Hayes. Philadelphia, PA: Mason Crest Publishers, 2003.

Schlun, Betsy van. Science and the Imagination: Mesmerism, Media, and the Mind in Nineteenth-Century English and American Literature. Glienicke, Berlin, Madison, WI: Galda + Wilch Verlag, 2007.

Schmidt, Burghart. Postmoderne: Strategien des Vergessens. Ein kritischer Bericht. Darmstadt: Luchterhand, 1986.

Schmidt, Regin. Red Scare: FBI and the Origins of Anticommunism in the United States, 1919-1943. Copenhagen: Museum Tusculanum Press, University of Copenhagen, 2000.

Schneider, Anne Larason. „Patterns of Change in the Use of Imprisonment in the American States: An Integration of Path Dependence, Punctuated Equilibrium and Policy Design Approaches.“ Political Research Quarterly. 2006, 59 (3):457-470.

Schneider, Volker, Frank Janning, Phillip Leifeld und Thomas Malang (Hg.). Politiknetzwerke: Modelle, Anwendungen und Visualisierungen. Wiesbaden: VS Verlag für Sozialwissenschaften, 2009.

Schneirov, Richard, Shelton Stromquist und Nick Salvatore (Hg.). The Pullman Strike and the Crisis of the 1890s: Essays on Labor and Politics. Urbana, IL: University of Illinois Press, 1999.

Schoening, Benjamin S. und Eric T. Kasper. Don't Stop Thinking About the Music: The Politics of Songs and Musicians in Presidential Campaigns. Lanham, MD: Lexington Books, 2012.

Schoonover, Thomas David (Hg.). Mexican Lobby: Matías Romero in Washington, 1861-1867. Lexington, KY: University Press of Kentucky, 1986.

Schoonover, Thomas David. „Dollars over Dominion: United States Economic Interests in Mexico, 1861-1867.“ Pacific Historical Review. 1976, 45 (1):23- 45

Schreier, Barbara A. Becoming American Women: Clothing and the Jewish Immigrant Experience, 1880-1920. Chicago, IL: Chicago Historical Society, 1994.

Schreiner, Samuel Agnew. Henry Clay Frick: The Gospel of Greed. New York: St. Martin's Press, 1995.

Schulman, Daniel und Meryl Treatner. The Freedmen's Bureau. New York: Macmillan/McGraw-Hill, 2002.

Schulze, Suzanne. Horace Greeley: A Bio-Bibliography. New York: Greenwood Press, 1992.

Schumpeter, Joseph A. Theorie der wirtschaftlichen Entwicklung. Leipzig: Duncker \& Humblot, 1911.

Schwab, James. Raising Less Corn and More Hell: Midwestern Farmers Speak Out. Urbana, IL: University of Illinois Press, 1988.

Schwantes, Carlos A. Coxey's Army: an American Odyssey. Moscow, ID: University of Idaho Press, 1994. 
Schwartz, Eric. A World Contender: Americans on the Global Stage 1900-1912. Philadelphia, PA: Mason Crest Publishers, 2005.

Schweninger, Loren. „Toward a Deeper Understanding of Reconstruction: The Freedman's Bureau, the Republican Party, and Northern Opinion in Post-Civil War America." Reviews in American History 22, no. 1 (1994):82-84.

Scipes, Kim. AFL-CIO's Secret War against Developing Country Workers: Solidarity or Sabotage? Lanham, MD: Lexington Books, 2010.

Scott, Robert. Blood at Sand Creek: The Massacre Revisited. Caldwell, ID: Caxton Printers, 1994.

Seager, Robert. Alfred Thayer Mahan: The Man and His Letters. Annapolis, MD: Naval Institute Press, 1977.

Seitz, Don Carlos. Joseph Pulitzer, His Life \& Letters. New York: AMS Press, 1970.

Seligman, Edwin Robert Anderson. The Income Tax: A Study of the History, Theory, and Practice of Income Taxation at Home and Abroad. Boston, MA: Adamant Media Corporation, 2001.

Seltzer, Curtis. Fire in the Hole: Miners and Managers in the American Coal Industry. Lexington, KY: University Press of Kentucky, 1985.

Senghaas, Dieter. On Perpetual Peace: A Timely Assessment. New York: Berghahn Books, 2007.

Sengoopta, Chandak. Darwin, Darwinism, and the Modern World. Prince Frederick, MD: Recorded Books, 2004.

Serrin, William. Homestead: The Glory and Tragedy of an American Steel Town. New York: Times Books, 1992.

Setterfield, Mark. „Expectations, Path Dependence and Effective Demand: A Macroeconomic Model along Keynesian Lines. “Journal of Post-Keynesian Economics 1999, 21 (3): $479-501$

Shafer, Byron E. Is America Different? A New Look at American Exceptionalism. Oxford, New York: Clarendon Press. Oxford University Press, 1991.

Shammas, Carole. „Anglo-American Household Government in Comparative Perspective.“ The William and Mary Quarterly 52, no. 1 (1995):104- 44.

Shannon, Fred A. The Farmer's Last Frontier: Agriculture, 1860-1897. White Plains, NY: M. E. Sharpe, 1977.

Shannon, Fred A. und Huhn Jones, Robert. The Centennial Years: A Political and Economic History of America from the Late 1870s to the Early 1890s. Garden City, NY: Doubleday, 1967.

Shapiro, Herbert. White Violence and Black Response from Reconstruction to Montgomery. Amherst: University of Massachusetts Press, 1988.

Sharrow, Walter G. „William Henry Seward and the Basis for American Empire, 1850-1860.“ Pacific Historical Review. 1967, 36 (3):325-342.

Shearer, Benjamin F. The Uniting States: The Story of Statehood for the Fifty United States. Westport, CT: Greenwood Press, 2004.

Sheffer, Jolie A. The Romance of Race: Incest, Miscegenation, and Multiculturalism in the United States, 1880-1930. New Brunswick, NJ: Rutgers University Press, 2013.

Sheinin, David. Beyond the Ideal: Pan Americanism in Inter-American Affairs. Westport, CT: Greenwood Press, 2000. 
Shenk, Wilbert R. North American Foreign Missions, 1810-1914: Theology, Theory, and Policy. Grand Rapids, MI: William B. Eerdmans Pub, 2004.

Sherrill, Charles Hitchcock. The Pan-Americanism of Henry Clay, Sarmiento and Root. Buenos Aires: J. Grant \& son, printers, 1909.

Sherwin, Oscar. Prophet of Liberty: The Life and Times of Wendell Phillips. Westport, CT: Greenwood Press, 1975.

Shingleton, Royce. Richard Peters: Champion of the New South. Macon, GA: Mercer University Press, 1985.

Shlomowitz, Ralph. „,Bound“ or ,Free‘? Black Labor in Cotton and Sugarcane Farming, 1865-1880.“ The Journal of Southern History 50, no. 4 (1984):569-596.

Shortell, Christopher. Rights, Remedies, and the Impact of State Sovereign Immunity. Albany, NY: State University of New York Press, 2008.

Shostak, Sara, Conrad, Peter und Horwitz, Allan V. „Sequencing and Its Consequences: Path Dependence and the Relationships between Genetics and Medicalization.“ American Journal of Sociology 2008, 114 (S1):287-316.

Shrock, Joel. The Gilded Age. Westport, CT: Greenwood Press, 2004.

Shumsky, Neil L. The Evolution of Political Protest and the Workingmen's Party of California. Columbus, OH: Ohio State University Press, 1991.

Shumway, George und Frey, Howard C. Conestoga Wagon, 1750-1850: Freight Carrier for 100 Years of America's Westward Expansion. York, PA: G. Shumway, 1968.

Sicherman, Barbara. Alice Hamilton: A Life in Letters. Urbana, IL: University of Illinois Press, 2003.

Sichrovsky, Harry. Der Revolutionär von Leitmeritz: Ferdinand Blumentritt und der philippinische Freiheitskampf. Wien: Österreichischer Bundesverlag, 1983.

Siegan, Bernard H. The Supreme Court's Constitution: An Inquiry into Judicial Review and Its Impact on Society. New Brunswick, NJ: Transaction Books, 1987.

Siemon-Netto, Uwe. „Sonderweg: The Closing of the German Mind.“ The National Interest, no. 70 (2002):33- 43.

Sigerman, Harriet. Elizabeth Cady Stanton: The Right Is Ours. New York: Oxford University Press, 2001.

Silagi, Michael. Henry George und Europa: Zur Entstehungsgeschichte der europäischen Bodenreformbewegungen. München: Etana, 1973.

Silver, Lindsay M. „The Nation's Neighborhood“: The People, Power, and Politics of Capitol Hill since the Civil War. Ann Arbor, MI: Proquest, 2007.

Simms, Brendan. The Impact of Napoleon: Prussian High Politics, Foreign Policy and the Crisis of the Executive, 1797-1806. Cambridge, New York: Cambridge University Press, 1997.

Simons, Anna. „The Death of Conquest.“ The National Interest. 2003 (71):41-49.

Simpson, Brooks D. Let Us Have Peace Ulysses S. Grant and the Politics of War and Reconstruction, 1861-1868. Chapel Hill: University of North Carolina Press, 1991.

Singles, Kathleen. Alternate History: Playing with Contingency and Necessity. Berlin: De Gruyter, 2013.

Sinke, Suzanne M. Dutch Immigrant Women in the United States, 1880-1920. Urbana, IL: University of Illinois Press, 2002.

Siry, Joseph. Carson Pirie Scott: Louis Sullivan and the Chicago Department Store. Chicago, IL: University of Chicago Press, 1988. 
Sismondo, Christine. America Walks into a Bar: A Spirited History of Taverns and Saloons, Speakeasies, and Grog Shops. New York: Oxford University Press, 2011.

Sivulka, Juliann. Soap, Sex, and Cigarettes: A Cultural History of American Advertising. Boston, MA: Wadsworth, Cengage Learning, 2012.

Skaggs, Jimmy M. The Great Guano Rush: Entrepreneurs and American Overseas Expansion. New York: St. Martin's Press, 1994.

Skidmore, Max J. Maligned Presidents: The Late 19th Century. New York: Palgrace MacMillan, 2014.

Sklar, Kathryn Kish. Florence Kelley and the Nation's Work: The Rise of Women's Political Culture, 1830-1900. New Haven, CT: Yale University Press, 1995-.

Sklar, Kathryn Kish, Schüler, Anja und Strasser, Susan. Social Justice Feminists in the United States and Germany: A Dialogue in Documents, 1885-1933. Ithaca, NY: Cornell University Press, 1998.

Sklar, Martin J. „The N. A. M. and Foreign Markets on the Eve of the Spanish-American War.“ Science \& Society 23, no. 2 (1959):133-62.

Skrabec, Quentin R. The 100 Most Significant Events in American Business: An Encyclopedia. Santa Barbara, CA: Greenwood, 2012.

Skrabec, Quentin R. The Carnegie Boys: The Lieutenants of Andrew Carnegie That Changed America. Jefferson, NC: McFarland \& Co, 2012.

Skrabec, Quentin R. George Westinghouse: Gentle Genius. New York: Algora Pub, 2007.

Skrabec, Quentin R. H. J. Heinz: A Biography. Jefferson, NC: McFarland \& Co, 2009.

Skrabec, Quentin R. Henry Clay Frick: The Life of the Perfect Capitalist. Jefferson, NC: McFarland \& Co, 2010.

Skrabec, Quentin R. William McKinley: Apostle of Protectionism. New York: Algora Pub, 2008.

Skurzynski, Gloria. Sweat and Blood: A History of U.S. Labor Unions. Minneapolis, MN: Twenty-First Century Books, 2008.

Slabaugh, Arlie R. Confederate States Paper Money: Civil War Currency from the South. Iola, WI: Krause Publications, 2008.

Slap, Andrew L. The Doom of Reconstruction: The Liberal Republicans in the Civil War Era. New York: Fordham University Press, 2006.

Slavishak, Edward. „Working-Class Muscle: Homestead and Bodily Disorder in the Gilded Age." The Journal of the Gilded Age and Progressive Era. 2004 Oct 1, 3 (4):339-368,

Sleeman, William. Preserving the Past: A Legislative History of the Freedman's Bureau Records Preservation Act of 2000. Buffalo, NY: W.S. Hein, 2006.

Slotkin, Richard. Regeneration through Violence: The Mythology of the American Frontier, 1600-1860. Middletown, CT: Wesleyan University Press, 1973.

Slotkin, Richard. The Fatal Environment: The Myth of the Frontier in the Age of Industrialization, 1800-1890. Norman, OK: University of Oklahoma Press, 1998.

Sluby, Patricia Carter. The Inventive Spirit of African Americans: Patented Ingenuity. Westport, CT: Praeger, 2004.

Smalley, Vern. Little Bighorn Mysteries: Issues Concerning the Approach to and Conduct of the Battle of the Little Bighorn. Bozeman, MT: Little Buffalo Press, 2005.

Smallwood, James, Howell, Kenneth Wayne und Taylor, Carol C.. The Devil's Triangle: Ben Bickerstaff, Northeast Texans, and the War of Reconstruction. Lufkin, TX: Best of East Texas Publishers, 2007.

Smiley, Jane. Moo: A Novel. New York: Anchor Books, 2009. 
Smith, Albert C. „,Southern Violence“ Reconsidered: Arson as Protest in Black-Belt Georgia, 1865-1910.“ The Journal of Southern History 51, no. 4 (1985):527-564.

Smith, Carl S. Urban Disorder and the Shape of Belief: The Great Chicago Fire, the Haymarket Bomb, and the Model Town of Pullman. Chicago, IL: The University of Chicago Press, 2007.

Smith, Craig R. Silencing the Opposition: Government Strategies of Suppression. Albany, NY: State University of New York Press, 1996.

Smith, Darrell Hevenor. The United States Civil Service Commission: Its History, Activities, and Organization. New York: AMS Press, 1974.

Smith, Earl und Hattery, Angela J.. „Incarceration: A Tool for Racial Segregation and Labor Exploitation.“ Race, Gender \& Class 15, no. 1/2 (2008):79-97.

Smith, Goldwin Albert. The Treaty of Washington, 1871: A Study in Imperial History. New York: Russell \& Russell, 1971.

Smith, Helmut Walser. „When the Sonderweg Debate Left Us.“ German Studies Review 31, no. 2 (2008):225-240.

Smith, Joseph. Historical Dictionary of United States-Latin American Relations. Lanham, MD: Scarecrow Press, 2007.

Smith, Robert Michael. From Blackjacks to Briefcases: A History of Commercialized Strikebreaking and Unionbusting in the United States. Athens, OH: Ohio University Press, 2003.

Smith, Robert Wayne. The Coeur D’Alene Mining War of 1892: A Case Study of an Industrial Dispute. Gloucester, MA: P. Smith, 1968.

Smith, Willard H. Schuyler Colfax: The Changing Fortunes of a Political Idol. Indianapolis, IN: Indiana Historical Bureau, 1952.

Smoak, Gregory E. Ghost Dances and Identity Prophetic Religion and American Indian Ethnogenesis in the Nineteenth Century. Berkeley, CA: University of California Press, 2006.

Snay, Mitchell. Horace Greeley and the Politics of Reform in Nineteenth-Century America. Lanham, MD: Rowman \& Littlefield, 2011.

Snipp, C. Matthew. American Indians: The First of This Land. New York: Russell Sage Foundation, 1989.

Söderlind, Sylvia und Carson, James Taylor. American Exceptionalisms from Winthrop to Winfrey. Albany: State University of New York Press, 2011.

Soennichsen, John Robert. The Chinese Exclusion Act of 1882. Santa Barbara, CA: Greenwood, 2011.

Solomon, Brian and Yough, Patrick. Coal Trains: The History of Railroading and Coal in the United States. Minneapolis, MN: MBI Pub. Company, 2009.

Somervill, Barbara A. Warren G. Harding. Minneapolis, MN: Compass Point Books, 2003.

Sorin, Gerald. A Time for Building: The Third Migration, 1880-1920. Baltimore, MD: Johns Hopkins University Press, 1992.

Soucek, Gayle. Marshall Field's the Store That Helped Build Chicago. Charleston, SC: History Press, 2010.

Sparrow, John C. History of Personnel Demobilization in the United States Army. Washington, DC: Dept. of the Army, 1952

Spears, Timothy B. Chicago Dreaming: Midwesterners and the City, 1871-1919. Chicago, IL: University of Chicago Press, 2005. 
Spitzer, Robert J. The Presidential Veto: Touchstone of the American Presidency. Albany, NY: State University of New York Press, 1988.

Stafford, Marshall P. The Life of James Fisk, Jr.: A Full and Accurate Narrative of All the Enterprises in Which He Was Engaged. New York: Arno Press, 1981.

Stage, Sarah. Female Complaints: Lydia Pinkham and the Business of Women's Medicine. New York: Norton, 1979.

Stalcup, Brenda. Reconstruction: Opposing Viewpoints. San Diego, CA: Greenhaven Press, 1995.

Stamp, Jimmy. Fact of Fiction? The Legend of the QWERTY Keyboard [Web Page]: http://www. smithsonianmag.com/arts-culture/fact-of-fiction-the-legend-of-the-qwerty-keyboard49863249/. Gesehen am 14. Februar 2017.

Stampp, Kenneth M. The Era of Reconstruction, 1865-1877. New York: Knopf, 1965.

Standiford, Les. Meet You in Hell: Andrew Carnegie, Henry Clay Frick, and the Bitter Partnership That Transformed America. New York: Crown Publishers, 2005.

Stanley, Amy Dru. „Beggars Can’t Be Choosers: Compulsion and Contract in Postbellum America.“ The Journal of American History 78, no. 4 (1992):1265-1293.

Stanley, Amy Dru. From Bondage to Contract: Wage Labor, Marriage, and the Market in the Age of Slave Emancipation. Cambridge, New York, NY: Cambridge University Press, 1998.

Starr, Timothy. Railroad Wars of New York State. Charleston, SC: History Press, 2012.

Steele, Brent J. „Ontological Security and the Power of Self-Identity: British Neutrality and the American Civil War.“ Review of International Studies. 2005, 31 (3):519-540.

Steen, Harold K. The U.S. Forest Service: A History. Durham, NC: University of Washington Press, 2004.

Steeples, Douglas und Whitten, David O.. Democracy in Desperation: The Depression of 1893. Westport, CT: Greenwood Press, 1998.

Stein, Leon und Taft, Philip. Workers Speak: Self-Portraits. New York: Arno, 1971.

Steiner, Dale R. Of Thee We Sing: Immigrants and American History. San Diego, CA: Harcourt Brace Jovanovich, 1987.

Stentiford, Barry M. The American Home Guard: The State Militia in the Twentieth Century. College Station, TX: Texas A\&M University Press, 2002.

Stephenson, D. Grier. The Waite Court: Justices, Rulings, and Legacy. Santa Barbara, CA: ABC-CLIO, 2003.

Sterman, John D. und Wittenberg, Jason. „Path Dependence, Competition, and Succession in the Dynamics of Scientific Revolution.“ Organization Science. 1999, 10 (3):322-341.

Stern, Clarence Ames. Protectionist Republicanism: Republican Tariff Policy in the McKinley Period. Ann Arbor, MI: Edwards Brothers, 1971.

Stewart, Charles Haines. Budget Reform Politics: The Design of the Appropriations Process in the House of Representatives, 1865-1921. Cambridge, New York: Cambridge University Press, 1989.

Stewart, David O. Impeached: The Trial of President Andrew Johnson and the Fight for Lincoln's Legacy. New York: Simon \& Schuster, 2009.

Stewart, James Brewer. Wendell Phillips: Liberty's Hero. Baton Rouge, LA: Louisiana State University Press, 1986.

Stewart, Richard W. American Military History. Washington, DC: Center of Military History, United States Army, 2009. 
Stites, Francis N. Private Interest \& Public Gain: The Dartmouth College Case, 1819. Amherst, MA: University of Massachusetts Press, 1972.

Stockley, Grif. Ruled by Race: Black/White Relations in Arkansas from Slavery to the Present. Fayetteville, AK: University of Arkansas Press, 2009.

Stockwell, Mary. Woodrow Wilson the Last Romantic. New York: Nova Science Publishers, Inc, 2008.

Stoddard, Lothrop. Master of Manhattan: The Life of Richard Croker. New York, Toronto: Longmans, Green and Co, 1931.

Stone, Richard D. The Interstate Commerce Commission and the Railroad Industry: A History of Regulatory Policy. New York: Praeger, 1991.

Stourzh, Gerald. From Vienna to Chicago and back: Essays on Intellectual History and Political Thought in Europe and America. Chicago, IL: University of Chicago Press, 2007.

Stout, Mary. Native American Boarding Schools. Santa Barbara, CA: Greenwood, 2012.

Stover, John F. The Life and Decline of the American Railroad. New York: Oxford University Press, 1970.

Stowell, David O. The Great Strikes of 1877. Urbana, IL: University of Illinois Press, 2008.

Stowell, David O. Streets, Railroads, and the Great Strike of 1877. Chicago, IL: University of Chicago Press, 1999.

Strachan, Hew. World War I: A History. Oxford, New York: Oxford University Press, 1998.

Strasser, Susan. Commodifying Everything: Relationships of the Market. New York: Routledge, 2003.

Strasser, Susan. Satisfaction Guaranteed: The Making of the American Mass Market. Washington, DC: Smithsonian Institution Press, 1995.

Stratton, Joanna L. Pioneer Women: Voices from the Kansas Frontier. New York: Simon and Schuster, 1981.

Strom, Claire. „Texas Fever and the Dispossession of the Southern Yeoman Farmer.“ The Journal of Southern History. 2000, 66 (1):49-74.

Strom, Sharon Hartman. Beyond the Typewriter: Gender, Class, and the Origins of Modern American Office Work, 1900-1930. Urbana, IL: University of Illinois Press, 1992.

Stromquist, Shelton. „United States of America.“ In: Marcel van der Linden und Jürgen Rojahn (Hg.). The Formation of Labour Movements, 1870-1914: An International Perspective. Leiden, New York: E.J. Brill, 1990, S. 543-578.

Stross, Randall E. The Wizard of Menlo Park: How Thomas Alva Edison Invented the Modern World. New York: Crown Publishers, 2007.

Strouse, Jean. Morgan: American Financier. New York: Perennial, 2000.

Stuart, Graham H. und Tigner, James Lawrence. Latin America and the United States. Englewood Cliffs, NJ: Prentice-Hall, 1975.

Stuart, Paul. The Indian Office: Growth and Development of American Institution, 1865-1900. Ann Arbor, MI: UMI Research Press, 1979.

Summerhill, Thomas. Harvest of Dissent: Agrarianism in Nineteenth-Century New York. Urbana, IL: University of Illinois Press, 2005.

Summers, Mark W. Railroads, Reconstruction, and the Gospel of Prosperity: Aid under the Radical Republicans, 1865-1877. Princeton, NJ: Princeton University Press, 1984.

Summers, Mark W. Rum, Romanism \& Rebellion the Making of a President, 1884. Chapel Hill, NC: University of North Carolina Press, 2000. 
Summers, Mark Wahlgren. „Party Games: The Art of Stealing Elections in the Late-Nineteenth-Century United States.“ The Journal of American History 88, no. 2 (2001):424- 435 .

Sunstein, Cass R. „Constitutionalism and Secession.“ The University of Chicago Law Review 58, no. 2 (1991):633-670.

Sutherland, Jonathan. African Americans at War: An Encyclopedia. Santa Barbara, CA: ABC-CLIO, 2004.

Svaldi, David. Sand Creek and the Rhetoric of Extermination: A Case Study in Indian-White Relations. Lanham, MD: University Press of America, 1989.

Swinney, Everette. Suppressing the Ku Klux Klan: The Enforcement of the Reconstruction Amendments, 1870-1877. New York: Garland, 1987.

Swint, Kerwin C. Mudslingers: The Twenty-Five Dirtiest Political Campaigns of All Time: Countdown from No. 25 to No. 1. New York: Union Square Press, 2008.

Swinton, John. A Momentous Question: The Respective Attitudes of Labor and Capital. New York: Arno, 1969.

Sy-Wonyu, Aissatou. „The Purchase of the Virgin Islands: W. H. Seward's View of Economic Strategy in the Late 19th Century.“ Cercles 5 (2002):11- 29.

Sydow, Jörg, Schreyögg, Georg und Koch, Jochen. „Organisatorische Pfade - Von der Pfadabhängigkeit zur Pfadkreation?“ In: Schreyögg, Georg und Sydow, Jörg (Hg.). Managementforschung 13. Wiesbaden: Gabler, 2003, S. 257-294.

Sydow, Jörg, Schreyögg, Georg und Koch, Jochen. „Organizational Path Dependence: Opening the Black Box." The Academy of Management Review. 2009, 34 (4):689-709.

Sydow, Jörg, Lerch, Frank und Staber, Udo. „Planning for Path Dependence? The Case of a Network in the Berlin-Brandenburg Optics Cluster.“ Economic Geography. 2010, 86 (2):173-196.

Sydow, Jörg und Schreyögg, Georg. The Hidden Dynamics of Path Dependence: Institutions and Organizations. Basingstoke, New York: Palgrave Macmillan, 2009.

Sylvers, Malcolm. „Marx, Engels und die USA - Ein Forschungsprojekt über ein wenig beachtetes Thema.“ Marx-Engels-Jahrbuch 2004. Internationale Marx-Engels-Stiftung, 31-53. Berlin: Akademie Verlag, 2005.

Syrett, John. The Civil War Confiscation Acts: Failing to Reconstruct the South. New York: Fordham University Press, 2005.

Szabo, Franz A. J. Kaunitz and Enlightened Absolutism, 1753-1780. Cambridge, New York: Cambridge University Press, 1994.

Szabo, Franz A. „Prince Kaunitz and the Primacy of Domestic Policy: A Response.“ The International History Review. 1980, 2 (4):625-635.

Tansill, Charles Callan. The United States and Santo Domingo, 1798-1873: A Chapter in Caribbean Diplomacy. Gloucester, MA: P. Smith, 1967.

Tappan, Eva March, Ploetz, Karl Julius, Tillinghast, William H. und Dresser, Horatio W.. The World's Story: A History of the World in Story, Song and Art. Boston, MA, New York: Houghton Mifflin Company, 1914.

Tarbell, Ida M. The Life of Elbert H. Gary: A Story of Steel. New York: Greenwood Press, 1969.

Tate, Michael L. The Frontier Army in the Settlement of the West. Norman, OK: University of Oklahoma Press, 1999.

Taylor, George Rogers und Irene D. Neu. The American Railroad Network, 1861-1890. Urbana, IL: University of Illinois Press, 2003. 
Taylor, Kay Ann. „Mary S. Peake and Charlotte L. Forten: Black Teachers during the Civil War and Reconstruction." The Journal of Negro Education 74, no. 2 (2005):124-137.

Tebbel, John William. The Marshall Fields: A Study in Wealth. New York: E.P. Dutton, 1947.

Tenório, Douglas Apratto. Capitalismo e Ferrovias no Brasil as Ferrovias em Alagoas. Maceió: EDUFAL, 1979.

Terrill, Tom E. The Tariff, Politics, and American Foreign Policy, 1874-1901. Westport, CT: Greenwood Press, 1973.

Teschke, Benno. The Myth of 1648: Class, Geopolitics, and the Making of Modern International Relations. London, New York: Verso, 2003.

Tett, Gillian. Fool's Gold: The Inside Story of J.P. Morgan and How Wall Street Greed Corrupted Its Bold Dream and Created a Financial Catastrophe. New York: Free Press, 2010.

The JBHE Foundation. „Lincoln's Second Inaugural: Press Reactions to the Most Eloquent Presidential Address in American History. “ The Journal of Blacks in Higher Education, no. 43 (2004): $44-46$.

Thelen, David. „The Nation and Beyond: Transnational Perspectives on United States History.“ The Journal of American History. 1999, 86 (3):965-975.

Theobald, Paul. Call School: Rural Education in the Midwest to 1918. Carbondale, IL: Southern Illinois University Press, 1995.

Thiemeyer, Guido. Internationalismus und Diplomatie: Währungspolitische Kooperation im europäischen Staatensystem 1865-1900. München: Oldenbourg, 2009.

Thomas, David Hurst. Skull Wars: Kennewick Man, Archaeology, and the Battle for Native American Identity. New York: Basic Books, 2000.

Thomas, Nicholas. Colonialism's Culture: Anthropology, Travel, and Government. Princeton, NJ: Princeton University Press, 1994.

Thompson, David. „Oliver Otis Howard: Reassessing the Legacy of the ,Christian General'.“ American Nineteenth Century. 10 (2009):273-298.

Thorne, Alison Comish. Visible and Invisible: Women in Land-Grant Colleges, 1890-1940. Logan, UT: Utah State University, 1985.

Thornton, Harrison John. The History of the Quaker Oats Company. Chicago, IL: The University of Chicago Press, 1933.

Thornton, Russell. American Indian Holocaust and Survival: A Population History since 1492. Norman, OK: University of Oklahoma Press, 1987.

Tindall, William. „A Sketch of Alexander Robey Shepherd.“ Records of the Columbia Historical Society, Washington, DC 14 (1911):49-66.

Todd, Anne M. Italian Immigrants, 1880-1920. Mankato, MN: Blue Earth Books, 2002.

Tokei, Ferenc. Essays on the Asiatic Mode of Production. Budapest: Akademiai Kiado, 1979.

Tompkins, E. Berkeley. Anti-Imperialism in the United States the Great Debate, 1890-1920. Philadelphia: University of Pennsylvania Press, 1970.

Tone, Andrea. „Black Market Birth Control: Contraceptive Enterpreneurship and Criminality in the Gilded Age." The Journal of American History 87, no. 2 (2000): 435-459.

Tortella Casares, Gabriel. Los Origenes del Capitalismo en España: Banca, Industria y Ferrocarriles en el Siglo XIX. Madrid: Tecnos, 1995.

Trachtenberg, Alan. The Incorporation of America: Culture and Society in the Gilded Age. New York: Hill and Wang, 2007.

Tracy, Kathleen. Henry Bessemer: Making Steel from Iron. Hockessin, DE: Mitchell Lane Publishers, 2006. 
Trafzer, Clifford E. As Long as the Grass Shall Grow and Rivers Flow: A History of Native Americans. Fort Worth, TX: Harcourt College Publishers, 2000.

Tragle, Henry Irving. Coxey's Army. New York: Grossman Publishers, 1974.

Trask, David F. The War with Spain in 1898. Lincoln, NE: University of Nebraska Press, 1996.

Trefousse, Hans L. Benjamin Franklin Wade: Radical Republican from Ohio. New York: Twayne Publishers, 1963.

Trefousse, Hans L. Carl Schurz: A Biography. New York: Fordham University Press, 1998.

Trefousse, Hans L. Impeachment of a President: Andrew Johnson, the Blacks, and Reconstruction. Knoxville, TN: University of Tennessee Press, 1975.

Trefousse, Hans L. Rutherford B. Hayes. New York: Times Books, 2002.

Trefousse, Hans L. Thaddeus Stevens: Nineteenth-Century Egalitarian. Chapel Hill: University of North Carolina Press, 1997.

Trelease, Allen W. White Terror: The Ku Klux Klan Conspiracy and Southern Reconstruction. Westport, CT: Greenwood Press, 1979.

Tschachler, Heinz. The Greenback: Paper Money and American Culture. Jefferson, NC: McFarland, 2010.

Tuck, Stephen G. N. We Ain't What We Ought to Be: The Black Freedom Struggle, from Emancipation to Obama. Cambridge, MA: Belknap Press of Harvard University Press, 2010.

Tucker, David M. Mugwumps: Public Moralists of the Gilded Age. Columbia: University of Missouri Press, 1998.

Tucker, Robert W. und Hendrickson, David C.. Empire of Liberty: The Statecraft of Thomas Jefferson. New York: Oxford University Press, 1990.

Tucker, Spencer. American Civil War: The Definitive Encyclopedia and Document Collection. Santa Barbara, CA: ABC Clio, 2013.

Tucker, Spencer. The Encyclopedia of the Spanish-American and Philippine-American Wars: A Political, Social, and Military History. Santa Barbara, CA: ABC-CLIO, 2009.

Tucker, Spencer, Arnold, James R. und Wiener, Roberta. The Encyclopedia of North American Indian Wars, 1607-1890: A Political, Social, and Military History. Santa Barbara, CA: ABC-CLIO, 2011.

Tunis, Edwin. Colonial Craftsmen and the Beginnings of American Industry. Baltimore, MD: Johns Hopkins University Press, 1999.

Turnbull, Stacy. Robert Speer: Denver’s Building Mayor. Palmer Lake, CO: Filter Press, LLC, 2011.

Twyman, Robert W. History of Marshall Field \& Co., 1852-1906. New York: Arno Press, 1976. Tyler, Alice Felt. The Foreign Policy of James G. Blaine. Hamden, CT: Archon Books, 1965. Uebele, Martin. International and National Wheat Market Integration in the 19th Century: A Comovement Analysis. Münster: WWU Münster, 2009.

Ueda, Reed und Wright, Conrad Edick. Faces of Community: Immigrant Massachusetts, 1860 - 2000. Boston, MA: Massachusetts Historical Society, 2003.

Uggen, Christopher und Manza, Jeff. „Democratic Contraction? Political Consequences of Felon Disenfranchisement in the United States.“ American Sociological Review 67, no. 6 (2002):777-803.

Ulrich, Bernd und Benjamin Ziemann. German Soldiers in the Great War: Letters and Eyewitness Accounts. Barnsley: Pen \& Sword Military, 2010. 
Unger, Irwin. The Greenback Era: A Social and Political History of American Finance, 1865-1879. Princeton, NJ: Princeton University Press, 1964.

Unger, Nancy C. Fighting Bob La Follette the Righteous Reformer. Madison, WI: Wisconsin Historical Society Press, 2008.

US Army Center of Military History. American Military History: The United States Army and the Forging of a Nation, 1775-1917. [Web Page]: http://www.history.army.mil/books/amh-v1/ ch13.htm. Gesehen am 5.5.2016.

US Department of State. „What We Do.“ [Web Page]: http://careers.state.gov/learn/what-wedo/mission. Gesehen am 13.7.2015.

Utley, Robert Marshall und Washburn, Wilcomb E. Indian Wars. Boston, MA: Houghton Mifflin, 2002.

Uviller, H. Richard und William G. Merkel. The Militia and the Right to Arms, or, How the Second Amendment Fell Silent. Durham, NC: Duke University Press, 2002.

Valera, Edmundo Eusebio Jr. „Imperialism of Righteousness“: The Influence of the American Social Gospel on Foreign Missions and Expansionism, 1890-1910. Dissertation, Fordham University, 1998.

Vandiver, Frank Everson. How America Goes to War. Westport, CT: Praeger, 2005.

Vargas, Oscar-René. Elecciones Presidenciales en Nicaragua, 1912-1932: Análisis Sociopolítico. Managua, Nicaragua: Fundación Manolo Morales, 1989.

Vargas, Oscar-René. La Intervención Norteamericana en Nicaragua y Sus Consecuencias, 1910-1925. Managua, Nicaragua: Centro de Investigaciones de la Realidad en América Latina. Centro de Investigación y Desarrollo Ecotextura, 1989.

Veggeland, Noralv. Paths of Public Innovation in the Global Age: Lessons from Scandinavia. Cheltenham, Northampton, MA: Edward Elgar, 2007.

Vergne, Jean-Philippe und Durand, Rodolphe. „The Missing Link between the Theory and Empirics of Path Dependence: Conceptual Clarification, Testability Issue, and Methodological Implications.“ Journal of Management Studies. 2010, 47 (4):736-759.

Vertovec, Steven. Transnationalism. London, New York: Routledge, 2009.

Vertovec, Steven und Cohen, Robin. Migration, Diasporas, and Transnationalism. Cheltenham, Northampton, MA: Edward Elgar, 1999.

Vielhaber, Carsten. Die Präfixe der Postmoderne oder wie man mit dem Mikroskop philosophiert. Münster: LIT, 2001.

Viereck, Peter. Unadjusted Man in the Age of Overadjustment: Where History and Literature Intersect. New Brunswick, NJ: Transaction Publishers, 2004.

Von Hoffman, Alexander. „An Officer of the Neighborhood: A Boston Patrolman on the Beat in 1895.“ Journal of Social History 26, no. 2 (1992):309-330.

Voss, Kim. The Making of American Exceptionalism: The Knights of Labor and Class Formation in the Nineteenth Century. Ithaca, NY: Cornell University Press, 1993.

Walett, Francis G. An Economic History of the United States: Summary of All Phases of Economic Growth. Abingdon: Routledge, 2006.

Walker, John F. und Vatter, Harold G.. The Rise of Big Government in the United States. Armonk, NY: M. E. Sharpe, 1997.

Walkowitz, Daniel J. „Working-Class Women in the Gilded Age: Factory, Community and Family Life among Cohoes, New York, Cotton Workers.“ Journal of Social History 5, no. 4 (1972):464-90. 
Wall, Bennett H., Carpenter, C. Gerald und Yeager, Gene S.. Growth in a Changing Environment: A History of Standard Oil Company (New Jersey), Exxon Corporation, 1950-1975. New York: McGraw-Hill, 1988.

Wallis, Eileen V. Earning Power: Women and Work in Los Angeles, 1880-1930. Reno, NE: University of Nevada Press, 2010.

Walsh, Margaret. The Rise of the Midwestern Meat Packing Industry. Lexington, KY: University Press of Kentucky, 1982.

Walters, Ryan S. The Last Jeffersonian: Grover Cleveland and the Path to Restoring the Republic. Bloomington, IN: Westbow Press, 2012.

Walton, Gary M. History of the American Economy. Mason, OH: Cengage, 2013.

Wang, Xi. The Trial of Democracy: Black Suffrage and Northern Republicans, 1860-1910. Athens, GA: University of Georgia Press, 1997.

Ward, Andrew. The Slaves' War: The Civil War in the Words of Former Slaves. Boston, MA: Houghton Mifflin Co, 2008.

Ward, Douglas B. A New Brand of Business: Charles Coolidge Parlin, Curtis Publishing Company, and the Origins of Market Research. Philadelphia, PA: Temple University Press, 2010.

Warren, Kenneth. The American Steel Industry, 1850-1970: A Geographical Interpretation. Pittsburgh, PA: University of Pittsburgh Press, 1988.

Warren, Kenneth. Big Steel: The First Century of the United States Steel Corporation, 1901-2001. Pittsburgh, PA: University of Pittsburgh Press, 2001.

Warren, Kenneth. Industrial Genius: The Working Life of Charles Michael Schwab. Pittsburgh, PA: University of Pittsburgh Press, 2007.

Warren, Kenneth. Triumphant Capitalism: Henry Clay Frick and the Industrial Transformation of America. Pittsburgh, PA: University of Pittsburgh Press, 1996.

Warren, Wilson J. Tied to the Great Packing Machine. The Midwest and Meatpacking. Iowa City, IO: University of lowa, 2007.

Washburn, Robert Collyer. The Life and Times of Lydia E. Pinkham. New York: Arno Press, 1976.

Washington, Delo E. „Education of Freedmen and the Role of Self-Help in a Sea Island Setting, 1862 -1982.“ Agricultural History 58, no. 3 (1984):442-55.

Waugh, Joan. Unsentimental Reformer: The Life of Josephine Shaw Lowell. Cambridge, MA: Harvard University Press, 1998.

Weaver, Frederick Stirton. An Economic History of the United States: Conquest, Conflict, and Struggles for Equality. Lanham, MD, London: Rowman \& Littlefield, 2016

Webb, George E. The Evolution Controversy in America. Lexington, KY: University Press of Kentucky, 2002.

Weber, Gabriele. Die europapolitische Rolle der Bundesrepublik Deutschland aus der Sicht ihrer EG-Partner: Deutscher Sonderweg oder europäische Musterrolle? Bonn: Europa Union, 1984.

Weber, Ronald. The Midwestern Ascendancy in American Writing. Bloomington, IN: Indiana University Press, 1992.

Webster, Laura Josephine. The Operation of the Freedmen's Bureau in South Carolina. New York: Russell \& Russell, 1970.

Weems, John Edward. The Fate of the Maine. College Station, TX: Texas A \& M University Press, 1992. 
Wehler, Hans-Ulrich. „1889: Wendepunkt der amerikanischen Außenpolitik: Die Anfänge des modernen Panamerikanismus - Die Samoakrise.“ Historische Zeitschrift 201, no. 1 (1965):57-109.

Wehler, Hans-Ulrich. Der Aufstieg des amerikanischen Imperialismus: Studien zur Entwicklung des Imperium Americanum 1865-1900. Göttingen: Vandenhoeck \& Ruprecht, 1974.

Wehler, Hans-Ulrich. Deutsche Gesellschaftsgeschichte. München: C.H. Beck, 1987-2008.

Wehler, Hans-Ulrich. Imperialismus. Königstein/Ts: Athenäum-Verlag. Droste, 1979.

Weig, Barbara. Resilienz komplexer Regionalsysteme: Brunsbüttel zwischen Lock-in und Lernprozessen. Wiesbaden: Springer, 2016.

Weinberg, Arthur und Shaffer Weinberg, Lila. The Muckrakers. Urbana, IL: University of Illinois Press, 2001.

Weinberg, Steve. Taking on the Trust: The Epic Battle of Ida Tarbell and John D. Rockefeller. New York: W.W. Norton, 2008.

Weir, Robert E. Beyond Labor's Veil: The Culture of the Knights of Labor. University Park, PA: Pennsylvania State University Press, 1996.

Weir, Robert E. Workers in America: A Historical Encyclopedia. Santa Barbara, CA: ABC-CLIO, 2013.

Weisbrod, Bernd. „Der englische ,Sonderweg“ in der Neueren Geschichte.“ Geschichte und Gesellschaft 16, no. 2 (1990):233-252.

Weiser, Eugene. The Pennsylvania Railroad. Seaford, DE: Dragonwick Pub, 2013.

Welch, Richard E. Imperialists vs. Anti-Imperialists: The Debate over Expansionism in the 1890’s. Itasca, IL: F. E. Peacock Publishers, 1972.

Welch, Richard E. Jr. „American Atrocities in the Philippines: The Indictment and the Response.“ Pacific Historical Review 43, no. 2 (1974): 233-53.

Wellenreuther, Hermann. „England und Europa: Überlegungen zum Problem des englischen Sonderwegs in der europäischen Geschichte.“ In: Norbert Finzsch und Hermann Wellenreuther. (Hg.). Liberalitas: Festschrift für Erich Angermann zum 65. Geburtstag. Stuttgart: F. Steiner, 1992, S. 89-124.

Wendt, Alexander. Social Theory of International Politics. Cambridge, UK, New York: Cambridge University Press, 1999.

Wenzlhuemer, Roland. Connecting the Nineteenth-Century World: The Telegraph and Globalization. Cambridge, New York: Cambridge University Press, 2013.

Wesley, Edgar B. „Forty Acres and a Mule and a Speller.“ History of Education Journal. 1959, 10 (1/4):56-70.

West, Jerry Lee. The Reconstruction Ku Klux Klan in York County, South Carolina, 1865-1877. Jefferson, NC: McFarland \& Co, 2002.

Westhoff, Laura M. A Fatal Drifting Apart: Democratic Social Knowledge and Chicago Reform. Columbus, OH: Ohio State University Press, 2007.

Westwood, Howard C. „Sherman Marched: And Proclaimed ,Land for the Landless.“ “ The South Carolina Historical Magazine 85, no. 1 (1984):33-50.

Wetta, Frank Joseph. The Louisiana Scalawags: Politics, Race, and Terrorism during the Civil War and Reconstruction. Baton Rouge, LA: Louisiana State University Press, 2012.

Wetzsteon, Ross. Republic of Dreams Greenwich Village, the American Bohemia, 1910-1960. New York: Simon \& Schuster, 2002.

Wheeler, Hoyt N. The Future of the American Labor Movement. Cambridge, New York: Cambridge University Press, 2002. 
Whitaker, Jan. Service and Style: How the American Department Store Fashioned the Middle Class. New York: St. Martin's Press, 2006.

Whitcomb, John und Whitcomb, Claire. Real Life at the White House: Two Hundred Years of Daily Life at America's Most Famous Residence. New York: Routledge, 2000.

White, Deborah G. Ar'n't I a Woman? Female Slaves in the Plantation South. New York: W.W. Norton, 1999.

White, Hayden V. Metahistory: The Historical Imagination in Nineteenth-Century Europe. Baltimore, MD: Johns Hopkins University Press, 1973.

White, Howard A. The Freedmen's Bureau in Louisiana. Baton Rouge, LA: Louisiana State University Press, 1970.

White, Ronald C. Liberty and Justice for All: Racial Reform and the Social Gospel (1877-1925). Louisville, KY: Westminster John Knox Press, 2002.

Whitelaw, Nancy. The Homestead Steel Strike of 1892. Greensboro, NC: Morgan Reynolds Pub, 2006.

Whitelaw, Nancy. Victory in Destruction: The Story of William Tecumseh Sherman. Greensboro, NC: Morgan Reynolds Pub, 2005.

Whitelaw, Nancy. William Tecumseh Sherman: Defender and Destroyer. Greensboro, NC: Morgan Reynolds, Inc, 1996.

Whites, LeeAnn. Gender Matters: Civil War, Reconstruction, and the Making of the New South. New York: Palgrave Macmillan, 2005.

Whittaker, Frederick. A Complete Life of General George A. Custer. Lincoln, NE: University of Nebraska Press, 1993.

Whitten, David O. und Whitten, Bessie E.. The Birth of Big Business in the United States, 1860 -1914: Commercial, Extractive, and Industrial Enterprise. Westport, CT: Praeger, 2006.

Widdis, Randy W. With Scarcely a Ripple: Anglo-Canadian Migration into the United States and Western Canada, 1880 -1920. Montreal, Ithaca, NY: McGill-Queen's University Press, 1998.

Widenor, William C. Henry Cabot Lodge and the Search for an American Foreign Policy. Berkeley, CA: University of California Press, 1980.

Wieland, Thomas. Neue Technik auf alten Pfaden? Forschungs- und Technologiepolitik in der Bonner Republik: Eine Studie zur Pfadabhängigkeit des technischen Fortschritts. Bielefeld: transcript, 2009.

Wiese, Andrew. Places of Their Own: African American Suburbanization in the Twentieth Century. Chicago, IL: University of Chicago Press, 2004.

Wiggins, Sarah Woolfolk. The Scalawag in Alabama Politics, 1865-1881. Tuscaloosa, AL: University of Alabama Press, 1991.

Wikipedia. Puddelverfahren. [Web Page]: https://de.wikipedia.org/wiki/Puddelverfahren. Gesehen am 13.3.2010.

Wilcove, David Samuel. No Way Home: The Decline of the World's Great Animal Migrations. Washington, DC: Island Press/Shearwater Books, 2008.

Wiley, Peter Booth und Korogi Ichiro. Yankees in the Land of the Gods: Commodore Perry and the Opening of Japan. New York: Viking, 1990.

Willert, James. Little Big Horn Diary: A Chronicle of the 1876 Indian War. El Segundo, CA: Upton, 1997. 
Williams, Lou Falkner. The Great South Carolina Ku Klux Klan Trials, 1871-1872. Athens, GA: University of Georgia Press, 2004.

Williams, Michael. Americans and Their Forests: A Historical Geography. Cambridge, New York: Cambridge University Press, 1989.

Williams, Miriam F. From Black Codes to Recodification Removing the Veil from Regulatory Writing. Amityville, NY: Baywood Pub, 2009.

Williams, Robert Chadwell. Horace Greeley: Champion of American Freedom. New York: New York University Press, 2006.

Williams, William Appleman. America and the Middle East: Open Door Imperialism or Enlightened Leadership? New York: Rinehart, 1958.

Williams, William Appleman. America Confronts a Revolutionary World, 1776-1976. New York: Morrow, 1976.

Williams, William Appleman. America in Vietnam: A Documentary History. Garden City, NY: Anchor Press/Doubleday, 1985.

Williams, William Appleman. American-Russian Relations, 1781-1947. New York: Octagon Books, 1971.

Williams, William Appleman. Americans in a Changing World: A History of the United States in the Twentieth Century. New York: Harper \& Row, 1978.

Williams, William Appleman. The Contours of American History. New York: W.W. Norton, 1988.

Williams, William Appleman. Empire as a Way of Life: An Essay on the Causes and Character of America's Present Predicament, Along With a Few Thoughts about an Alternative. New York: Oxford University Press, 1980.

Williams, William Appleman. From Colony to Empire: Essays in the History of American Foreign Relations. New York: J. Wiley, 1972.

Williams, William Appleman. The Great Evasion: An Essay on the Contemporary Relevance of Karl Marx and on the Wisdom of Admitting the Heretic into the Dialogue about America's Future. Chicago, IL: Quadrangle Books, 1964.

Williams, William Appleman. The Roots of the Modern American Empire: A Study of the Growth and Shaping of Social Consciousness in a Marketplace Society. New York: Random House, 1969.

Williams, William Appleman. The Shaping of American Diplomacy. Chicago, IL: Rand McNally, 1970-.

Williams, William Appleman. The Tragedy of American Diplomacy. New York: W.W. Norton \& Co, 2009.

Williams, William Appleman. The United States, Cuba, and Castro: An Essay on the Dynamics of Revolution and the Dissolution of Empire. New York: Monthly Review Press, 1962.

Willis, John C. Forgotten Time the Yazoo-Mississippi Delta After the Civil War. Charlottesville: University Press of Virginia, 2000.

Willis, Martin. Mesmerists, Monsters, and Machines: Science Fiction and the Cultures of Science in the Nineteenth Century. Kent, OH: Kent State University Press, 2006.

Wilm, Julius. „Free Land for Settlers: An American Dream and Its Realities in the Antebellum Era“. Dissertation, Universität zu Köln, 2016.

Wilson, Bobby M. America's Johannesburg: Industrialization and Racial Transformation in Birmingham. Lanham, MD: Rowman \& Littlefield Publishers, 2000.

Wilson, Charles Morrow. The Monroe Doctrine: An American Frame of Mind. Princeton, NJ: Auerbach, 1971. 
Wilson, G. Lloyd und Spencer, Ellwood H. . „Growth of the Railroad Network in the United States.“ Land Economics 26, no. 4 (1950):337-345.

Wilson, James G. The Imperial Republic: A Structural History of American Constitutionalism from the Colonial Era to the Beginning of the Twentieth Century. Aldershot, Burlington, VT: Ashgate, 2002.

Wilson, Mark. The Business of Civil War: Military Mobilization and the State, 1861-1865. Baltimore: Johns Hopkins University Press, 2006.

Wilson, Theodore Brantner. The Black Codes of the South. University, AL: University of Alabama Press, 1965.

Wimmer, Andreas und Kössler, Reinhart. Understanding Change: Models, Methodologies, and Metaphors. Houndmills, Basingstoke, Hampshire, New York: Palgrave Macmillan, 2006.

Wimmer, Andreas and Schiller, Nina Glick. Methodological Nationalism and the Study of Migration. European Journal of Sociology. 2002, 43 (2):217-240.

Winkler, Heinrich August. „Und erlöse uns von der Kriegsschuld.“ Die Zeit 32 (2014).

Winter, J. M. The Legacy of the Great War: Ninety Years on. Columbia, Kansas City, MO: University of Missouri Press, 2009.

Witt, John Fabian. The Accidental Republic: Crippled Workingmen, Destitute Widows, and the Remaking of American Law. Cambridge, MA: Harvard University Press, 2004.

Wolcott, David B. und Head, Tom. Crime and Punishment in America. New York: Facts on File, 2010.

Wolff, Joshua D. Western Union and the Creation of the American Corporate Order, 1845-1893. Cambridge, New York: Cambridge University Press, 2013.

Wolmar, Christian. The Great Railroad Revolution: The History of Trains in America. New York: PublicAffairs, 2012.

Woloch, Nancy. Muller v. Oregon: A Brief History with Documents. Boston, MA: Bedford Books of St. Martin's Press, 1996.

Wood, Amy Louise. Violence. Chapel Hill, NC: University of North Carolina Press, 2011.

Woodiwiss, Michael. Organized Crime and American Power: A History. Toronto, Buffalo, NY, London: University of Toronto Press, 2001.

Woodward, C. Vann. Reunion and Reaction: The Compromise of 1877 and the End of Reconstruction. New York, Oxford: Oxford University Press, 1991.

Woodward, C. Vann. Tom Watson: Agrarian Rebel. Oxford: Oxford University Press, 1963.

Worster, Donald. Dust Bowl: The Southern Plains in the 1930s. New York: Oxford University Press, 2004.

Worth, Richard. Sherman Antitrust Act. New York: Marshall Cavendish Benchmark, 2012.

Wright, Gavin. „Persisting Dixie: The South as an Economic Region.“In: Craig S. Pascoe, Karen Trahan Leathem und Andy Ambrose (Hg.). The American South in the Twentieth Century. Atlanta, GA, Athens, GA: Atlanta History Center. University of Georgia Press, 2005, S. 77-90.

Wright, George C. Racial Violence in Kentucky, 1865-1940: Lynchings, Mob Rule, and „Legal Lynchings.“ Baton Rouge, LA: Louisiana State University Press, 1990.

Wunder, John R. „,Merciless Indian Savages’ and the Declaration of Independence: Native Americans Translate the Ecunnaunuxulgee Document.“ American Indian Law Review. 2000, 25 (1):65-92.

Wyman, Mark. Hoboes: Bindlestiffs, Fruit Tramps, and the Harvesting of the West. New York: Hill and Wang, 2010. 
Xin, Gu. Path Dependence, Institutional Embeddedness, and Institutional Change. Singapore: East Asian Institute, 1999.

Yániz Ruiz, Juan Pedro. „1848-1860: Expediciones Filibusteras contra Cuba.“ Historia y Vida 16, no. 178 (1983):68-87.

Yanow, Dvora. Constructing „Race“ and „Ethnicity“ in America: Category-Making in Public Policy and Administration. Armonk, NY: M. E. Sharpe, 2003.

Yates, Jeff und Fording, Richard. „Politics and State Punitiveness in Black and White.“ The Journal of Politics 67, no. 4 (2005):1099-1121.

Yesuf, Mahmud und Bluffstone, Randall A. „Poverty, Risk Aversion, and Path Dependence in Low-Income Countries: Experimental Evidence from Ethiopia.“ American Journal of Agricultural Economics. 2009, 91 (4):1022-1037.

Yeung, Godfrey. „Hybrid Property, Path Dependence, Market Segmentation and Financial Exclusion: The Case of the Banking Industry in China." Transactions of the Institute of British Geographers. 2009, 34 (2):177-194.

Young, Bette Roth. Emma Lazarus in Her World: Life and Letters. Philadelphia, PA: Jewish Publication Society, 1995.

Young, Biloine W., Eileen R. McCormack und Annette Atkins. The Dutiful Son: Louis W. Hill Life in the Shadow of the Empire Builder, James J. Hill. St. Paul, MN: Ramsey County Historical Society, 2010.

Young, William H. und Nancy K. Young. The Great Depression in America: A Cultural Encyclopedia. Westport, CT: Greenwood Press, 2007.

Zeigler, Robert. „Cowboy Strike of 1883.“ Handbook of Texas Online. [Web Page]: https:// tshaFSonline.org/handbook/online/articles/oec02. Gesehen am 1. Oktober 2008.

Zieger, Robert H. For Jobs and Freedom: Race and Labor in America since 1865. Lexington, KY: University Press of Kentucky, 2007.

Ziegler, Vanessa Michelle. „The Revolt of ,the Everfaithful Isle': The Ten Years' War in Cuba, 1868-1878.“ Dissertation, University of California, 2007.

Zima, Peter V. Moderne/Postmoderne: Gesellschaft, Philosophie, Literatur. Tübingen: Francke, 2001.

Zimmerman, Mosche. Darkah Ha-Meyuhedet Shel Germanyah Ba-Historyah. Yerushalayim: Hotsa'at sefarim ‘a. sh. Y.L. Magnes, ha-Universitah ha-'Ivrit, 1989.

Zimmermann, Matilde. Sandinista: Carlos Fonseca and the Nicaraguan Revolution. Durham, NC: Duke University Press, 2000.

Zink, Harold. City Bosses in the United States: A Study of Twenty Municipal Bosses. Durham, NC: Duke University Press, 1930.

Zinn, Howard und Arnove, Anthony. Voices of a People's History of the United States. New York: Seven Stories Press, 2004.

Zinzen, Arthur. Dampfkessel und Feuerungen: Ein Lehr- und Handbuch. Berlin: Springer, 1957.

Zipf, Karin L. Labor of Innocents: Forced Apprenticeship in North Carolina, 1715-1919. Baton Rouge, LA: Louisiana State University Press, 2005.

Zook, Ellsworth Erving. James G. Blaine and the Mulligan Letters. Madison, WI: University of Wisconsin, 1918.

Zuczek, Richard. State of Rebellion: Reconstruction in South Carolina. Columbia, SC: University of South Carolina Press, 1996.

Zunz, Olivier. Making America Corporate, 1870-1920. Chicago, IL: University of Chicago Press, 1990. 
Zwick, Jim. Mark Twain's Weapons of Satire: Anti-Imperialist Writings on the Philippine-American War. Syracuse, NY: Syracuse University Press, 1992. 